\title{
Cloudbursts in Indian Himalayas: a review
}

Article

Accepted Version

Creative Commons: Attribution-Noncommercial-No Derivative Works 4.0

Dimri, A. P., Chevuturi, A., Niyogi, D., Thayyen, R. J., Ray, K., Tripathi, S. N., Pandey, A. K. and Mohanty, U. C. (2017) Cloudbursts in Indian Himalayas: a review. Earth-Science Reviews, 168. pp. 1-23. ISSN 0012-8252 doi: https://doi.org/10.1016/j.earscirev.2017.03.006 Available at https://centaur.reading.ac.uk/69722/

It is advisable to refer to the publisher's version if you intend to cite from the work. See Guidance on citing.

To link to this article DOI: http://dx.doi.org/10.1016/j.earscirev.2017.03.006

Publisher: Elsevier

All outputs in CentAUR are protected by Intellectual Property Rights law, including copyright law. Copyright and IPR is retained by the creators or other copyright holders. Terms and conditions for use of this material are defined in the End User Agreement.

\section{www.reading.ac.uk/centaur}

\section{CentAUR}

Central Archive at the University of Reading

Reading's research outputs online 


\section{Accepted Manuscript}

Cloudbursts in Indian Himalayas: A review

A.P. Dimri, A. Chevuturi, D. Niyogi, R.J. Thayyen, K. Ray, S.N.

Tripathi, A.K. Pandey, U.C. Mohanty

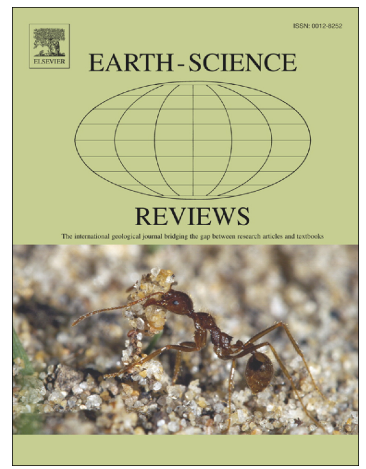

PII:

S0012-8252(16)30488-3

DOI:

doi: 10.1016/j.earscirev.2017.03.006

Reference:

EARTH 2396

To appear in: $\quad$ Earth-Science Reviews

Received date: $\quad 24$ December 2016

Revised date: $\quad 25$ February 2017

Accepted date: $\quad 14$ March 2017

Please cite this article as: A.P. Dimri, A. Chevuturi, D. Niyogi, R.J. Thayyen, K. Ray, S.N. Tripathi, A.K. Pandey, U.C. Mohanty, Cloudbursts in Indian Himalayas: A review. The address for the corresponding author was captured as affiliation for all authors. Please check if appropriate. Earth(2016), doi: 10.1016/j.earscirev.2017.03.006

This is a PDF file of an unedited manuscript that has been accepted for publication. As a service to our customers we are providing this early version of the manuscript. The manuscript will undergo copyediting, typesetting, and review of the resulting proof before it is published in its final form. Please note that during the production process errors may be discovered which could affect the content, and all legal disclaimers that apply to the journal pertain. 


\title{
Cloudbursts in Indian Himalayas: A Review
}

\author{
A. P. Dimri ${ }^{@}$, A. Chevuturi $^{\circledR, \#}$, D. Niyogi ${ }^{\$}$, R. J. Thayyen ${ }^{\%}$, K. Ray ${ }^{\wedge}$, S. N. Tripathi ${ }^{\circledR}$, A. K. \\ Pandey ${ }^{*}$ and U. C. Mohanty!! \\ ${ }^{\circledR}$ School of Environmental Sciences, Jawaharlal Nehru University, New Delhi, India \\ ${ }^{\#}$ National Centre for Atmospheric Sciences - Climate, Department of Meteorology, University \\ of Reading, Reading, UK \\ ${ }^{\$}$ Purdue University, West Lafayette, Indiana, US \\ ${ }^{\%}$ National Institute of Hydrology, Roorkee, Uttarakhand, India \\ India Meteorological Department, New Delhi, India \\ ${ }^{\&}$ Centre for Environmental Science \& Engineering, Indian Institute of Technology, Kanpur, \\ Uttar Pradesh, India \\ *National Geophysical Research Institute, Hyderabad, India \\ !'School of Earth, Ocean and Climate Sciences, Indian Institute of Technology, Bhubaneswar, \\ Orissa, India
}

Address for correspondence: Prof A. P. Dimri, School of Environmental Sciences, Jawaharlal Nehru University, New Delhi, India. Email: apdimri@ hotmail.com

\begin{abstract}
Cloudbursts in and around the southern rim of the Indian Himalayas are elusive in terms of their position and time of occurrences. Most of the reported cloudbursts are in the interior of the Himalayas and hence their observation itself is limited. Most of these events are reported once their affect in terms of loss to life and property is experienced in the downstream habitats. In addition, they are mostly associated with flash floods as an impact of the torrential precipitation. The principal understanding of the cloudburst is associated with sudden heavy
\end{abstract}


deluge of precipitation in very less time interval over a very small area. Except this understanding and India Meteorology Department (IMD) definition of $>100 \mathrm{~mm} / \mathrm{h}$ precipitation over a geographical region of approximately $20-30 \mathrm{Km}^{2}$, nothing much else is known about these events. There are a very few studies carried out on understanding of these events. Present paper synthesizes the available information and research on cloudburst events and tries to define it based on associated dynamics, thermodynamics and physical processes leading to a cloudburst event. Thus in the present work, characterizations and impacts of cloudburst leading from precipitation to dynamical to thermodynamical to large scale forcings to orographical forcings to followed geomorphology to impacts are intertwined to present comprehensive portray of it.. Most of the cloudburst events are seen occurring in the elevation range of $1000 \mathrm{~m}$ to $2500 \mathrm{~m}$ within the valley folds of the southern rim of the Indian Himalayas. Apart from some of the large scale flow shown by few of the studies, it is found that cloudburst events are convectively triggered followed by orographically locked systems. These intertwined mechanisms lead cloudburst events to form. Amiss of any one of these mechanisms will not lead the cloudburst mechanism to form. These interactions in the present paper established the vagaries associated with the cloudburst events.

Key Words: Cloudburst, convective trigger-orographic locking, valley folds, Indian Himalayas

\section{Introduction}

In the recent decades vagaries associated with 'cloudburst' events are frequently reported in and around the southern rim of the Indian Himalayas. Most of these cases are associated with unexpected heavy precipitation. The Himalayan orography with its steep and unstable inclines forms a perfect platform for such a cloudburst event to lead to flash floods or landslides. Predicting the location, amplitude and magnitude of such catastrophic events in advance remains 
a challenge. Various researchers have worked on case base studies associated with the cloudburst events right from reconstruction from geomorphic signature of the hindcast case (Hobley et al., 2012) to the observations studies (Gupta et al., 2013; Juyal, 2010) and to the modelling studies (Thayyen et al., 2012; Kumar et al., 2012). Rasmussen and Houze (2012) and Kumar et al. (2014) have extensively provided signature of large scale flow and topographic interactions associated with Leh cloudburst event, 2010. With modelling efforts, Das et al. (2006) have provided an insight of a cloudburst event and associated dynamical interactions with the topography. Upadhyay (1995) suggested most of these events in mountainous regions are associated with cumulonimbus or thunder clouds. In a very short time span over a much localized area heavy downpour ranging from $200-1000 \mathrm{~mm} / \mathrm{h}$ occurs in these events (Deoja et al., 1991). Corresponding droplet size ranges from $\sim 4-6 \mathrm{~mm}$ with fall speed of $\sim 10 \mathrm{~m} / \mathrm{s}$ (Singh and Sen, 1996). Joshi (2006) based on four years precipitation analysis over the Ukhimath region of the central Himalayan has shown increase in such extreme events. Gupta et al. (2013) have studied the cloudburst event of 3 Aug 2012 occurred over the Asi Ganga, a tributary of the Bhagirathi river, in Garhwal Himalayas. This study remains limited to associated flash flood, geomorphic details and impacts etc. on the society. But the study mentions that the orographic architecture of the mountain regions makes them ideal for generating localized cyclonic storms in the confines of a closed valley which lead to cloudbursts. Sah and Mazari (2007) reported occurrence of most of these cloudburst events mainly during the monsoonal periods, restricting over mainly headwater areas of closed tributaries/valleys. Joshi (1997) has reported damage in the two of the river basins in Garhwal Himalayas due to cloudburst occurrence during 1997 monsoon. In addition he provided people's perspective, mechanism and impact of cloudburst over the Central Himalayas. Bhandari and Gupta (1985) has reported cloudburst events and 
associated impacts over the northeast Indian Himalayas. Joshi and Makhuri (1997) have illustrated on impacts due to one of the cloudburst occurred in central Himalayan region in 1992. Juyal (2010) has reported on sight evolution of Leh cloudburst of 6 Aug 2010. Das et al. (2006), probably, first time provided the dynamical structure, physical processes and orographic interactions associated with one of the cloudbursts occurred over the central Himalayan region on $16 \mathrm{Jul}$ 2003. Using modelling strategies, they concluded that low-level convergence of southeasterlies and northeasterlies along the foothills coupled with vertical shear in wind and orographic uplifting leading to a short-lived, intensely precipitating convective storm (cloudburst)'. The paper also provides a general definition of a cloudburst event (as also adopted by IMD) as a weather phenomenon with unexpected precipitation exceeding $100 \mathrm{~mm} / \mathrm{h}$ over a geographical region of approximately 20-30 $\mathrm{Km}^{2}$. Dimri (2013), however, indicated status on early warning systems associated with such hazards as early as in 1894. Bhan et al. (2004) have objectively summarised that most of the cloudburst events occur during monsoon season with higher frequency during the months of Jul and Aug. Bhan et al. (2015) further suggested these events to be associated with westward moving cyclonic circulations in middle troposphere ( 500hPa) over the Tibet-Ladhak region during active monsoon conditions. Sikka et al. (2015) and Ray et al. (2015) have also suggested the interaction of low level westward moving monsoonal systems and eastward moving mid-tropospheric westerly trough as one of the main causes of catastrophic floods over Uttarakhand in 2013 and Jammu \& Kashmir in 2014, but have ruled out the possibility of cloudburst based on IMD's definition. This established the fact that such positioning and timing is crucial for occurrence of cloudburst events over the Himalayan region. 
In case of heavy deluge events associated with mesoscale convection occurred over Indian sub-continent various researchers have provided dynamical understanding. Semwal and Dimri (2010) have demonstrated role of microphysics parameterization during the Mumbai deluge. While studying the same case with high-resolution Weather and Research Forecast (WRF) modelling framework, Kumar et al. (2008) have shown mesoscale vortex over the Mumbai resulting in heavy precipitation. By introducing radiative transfer scheme in a mesoscale numerical weather model better physical relationship is seen between radiative quantities and cloud water or rain rates (Schomburg et al., 2012). Further, Rajeevan et al. (2010) have demonstrated sensitivity of microphysical schemes on thunderstorm occurred over southeast India. In another experiment for understanding mesoscale convective systems (MCSs), Done et al. (2004) have shown increased accuracy in prediction of convective system mode over Mid America Airport, Illinois, US by employing explicit scheme. Similar experiment with explicit convective parameterization within WRF framework has shown added values for high resolution forecast of convective system mode (Weisman et al., 2008). Studying two of the north-Alpine heavy precipitation events, Zangl (2007) has shown fact of proper representation of topography for explaining better small-scale precipitation variability. Over Indian Himalayan region, Das (2005) has demonstrated strength of mesoscale model for weather forecast.

In Indian meteorological parlance, though, particularly cloudburst events are frequently referred across in numerous researches, but are not well defined and lack in their assessment and understanding. These events are governed by much unknown complex convective and orographic processes. Hence, so far no set definition leading to cloudburst is provided. It is primarily linked to the high precipitation event over much localised area in very short time span. As per the IMD, cloudburst phenomenon characterized by high intensity precipitation, usually 
more than $100 \mathrm{~mm} / \mathrm{h}$, within a short span of time, over a small area. But then this definition remains to be very qualitative and associated dynamics and thermodynamics in correspondence with orographic interactions over the Indian Himalayas remain missing.

Keeping these facts in view present study attempts to provide understanding of physical and dynamical and other important processes associated with cloudburst events within following objectives.

\section{Objectives}

1. To study through extreme precipitation index to find out if the cloudbursts are captured over Indian Himalayas

2. To analyze large scale forcings causing the heavy precipitation associated with cloudbursts

3. To conceptualize the cause of and define cloudbursts as a localized precipitating event by describing the local forcings

\section{Data and Methodology}

\subsection{Data used and referred in the present study}

Local flash flood information are collected from Office of the Tahsildar, and I\&FC, Leh (Ladhak), India. Various sources of cloudbursts reported within the southern rim of the Indian Himalayas are considered to compile the present review. Some of the sources are from print and public media (which at times only report the occurrence from societal point of view and do not have much research and science attached to it). Due to lack of the station observations over the data sparse Indian Himalayas, available global observational datasets have been utilized for the study. The observational datasets used in this study include: 
1. National Aeronautics and Space Administration (NASA) Modern-Era Retrospective Analysis for Research and Applications (MERRA) (Rienecker et al., 2011) dataset with 6 hourly three-dimensional atmospheric analyses: Goddard Earth Observing System data assimilation System version $5($ GEOS-5) is used to generate this meteorological data assimilation product at a spatial resolution of $0.5^{\circ} \times 0.7^{\circ}$ available from 1979 onwards. This dataset is downloaded from http://disc.sci.gsfc.nasa.gov/daacbin/FTPSubset.pl?LOOKUPID_List=MAI3CPASM.

2. Version 7 Tropical Rainfall Measuring Mission (TRMM) Multi-satellite Precipitation Analysis (TMPA) (Huffman et al., 2007) daily derived precipitation and 3 hourly rain rate data: TRMM multi-satellite precipitation analyses have a spatial resolution of $0.25^{\circ} \mathrm{x}$ $0.25^{\circ}$ available from 1998 onwards. TRMM datasets focus on tropical region precipitation and thus have a horizontal coverage of $180^{\circ} \mathrm{W}-180^{\circ} \mathrm{E}$ and $50^{\circ} \mathrm{S}-50^{\circ} \mathrm{N}$ and is downloaded from ftp://disc2.nascom.nasa.gov/data/TRMM/Gridded/.

3. Climate prediction centre MORPHing (CMORPH) technique (Joyce et al., 2004) generated precipitation dataset: This provides global precipitation estimated from passive microwave and infrared satellite data available from 2002 onwards. CMORPH data is having 30 min temporal resolution and $8 \mathrm{~km}$ spatial resolution and daily precipitation estimates at $0.25^{\circ} \times 0.25^{\circ}$ spatial resolution. This is the reprocessed data denoted CMORPH version 1.0 with gauge and satellite blended precipitation estimates and is downloaded from ftp://ftp.cpc.ncep.noaa.gov/precip/CMORPH_V1.0/CRT/ datasets are used in this.

4. Outgoing Longwave Radiation (OLR) data of the National Oceanic and Atmospheric Administration (NOAA) interpolated OLR (Liebmann and Smith, 1996): This global 
dataset is available at $2.5^{\circ} \times 2.5^{\circ}$ horizontal spatial resolution from 1974 onwards. This data is provided by Earth Systems Research Laboratory, NOAA, USA and is downloaded from http://www.esrl.noaa.gov/psd/data/gridded/data.interp_OLR.html.

5. Hourly observation precipitation records are taken from Self Recording RainGauge (SRRG) stations of India Meteorological Department, India.

\subsection{Methodologies adopted by various researches to define cloudburst}

In the Indian Himalayas, exact location and timing of cloudbursts are very elusive as being much localised convective events their occurrences are less monitored/observed. These events are reported due to their associated impacts of flash floods, damages etc. in the downstream basins. In addition, due to lack of station observations over data sparse Indian Himalayan region, at times corresponding analysis and understanding of cloudburst mechanism becomes challenging. At times local cloudbursts leading to flash flood information are collected at some of the local government offices. And some of the documentations and listings of these events are available from the other published works and literatures. Available cloudburst events are collected from various sources across the southern rim of the Indian Himalayas and are listed in Table 1. It provides details, damages and associated precipitation reported by various sources. Corresponding position of these cloudbursts are marked along with the Himalayan topography in Fig. 1. Most of the researches to understand their mechanism remained objective (Joshi and Maikhuri, 1997; Joshi, 2006; Juyal, 2010; Gupta et al., 2013). However in the recent decade, a few of the researches highlighted the associated dynamics by employing modelling framework (Das et al., 2006; Kumar et al., 2012; Thayyen et al., 2013; Kumar et al., 2014; Rasmussen and Houze, 2012; Shrestha et al., 2015). Using clustering technique, Pabreja (2012) has analysed Leh cloudburst event of 06 Aug 2010. Hobley et al. (2012) have provided reconstruction of this event 
using geomorphic signatures. They could demonstrate the intensity within the downstream basin in the Leh catchment. Chaudhuri et al. (2015) studied formation of a cloudburst based on analysis of observation and modelling efforts. In their work they studied back trajectory of the event as well. In the present study, five different cloudbursts, out of many described in Table 1, over the Indian Himalayas (Leh region) are studied based on observational and modelling strategies to arrive comprehensive definition of it.

\section{Results and Discussion}

In the present review authors tried to discuss findings on most of the important issues linked with cloudburst events right from precipitation details - dynamical forcing - orographic forcing - geomorphology - impact on society etc. in the following sections.

\subsection{Cloudbursts and associated precipitation}

The upper air flow pattern over the Indian sub-continent including the Himalayan region is governed mainly by the subtropical ridge and its movement with seasons. The continental effects, reflected in large annual and diurnal range of temperatures are more prominent towards west than the central or eastern part of Himalayas (Pangtey and Joshi, 1987).Towards the end of May the upper air circulation over the Himalayas undergoes a significant change. The subtropical high pressure ridge (STR) shifts northwards rather abruptly (at about the time of onset of the Indian summer monsoon (ISM) over the Indian subcontinent).

Based on 1961 - 1990 wind climatology, during April, pre-monsoon period, westerly flow dominates at $300 \mathrm{hPa}$ over the Indian subcontinent. Stronger core of westerly of the order of 60 knots remains over the eastern central India at and around $25^{\circ} \mathrm{N} 90^{\circ} \mathrm{E}$, Fig. 2a. At further higher level of $100 \mathrm{hPa}$, westerlies remain with an associated anticyclonic flow over the Indian Ocean, Fig. 2b. During July, monsoon period, at 300hPa and 200hPa levels, Fig. 2c, the STR lies 
between $27^{\circ} \mathrm{N}$ to $32^{\circ} \mathrm{N}$. At $100 \mathrm{hPa}$, Fig. $2 \mathrm{~d}$, it further moves northwards and lies over central parts of the Himalayan region (roughly at $32^{\circ} \mathrm{N}$ ) and the anticyclonic circulation covers the entire Himalayan belt. Easterly winds prevail to the south of the subtropical high. These easterlies increase in speed rapidly with height from 200hPa, reaching a maximum strength between $150 \mathrm{hPa}$ and 100hPa (IMD, 2003). With the withdrawal of the monsoon, the STR begins its southward movement and the upper air flow over the Himalayan region reverts to winter regime. As per records and literature most of the cloudbursts have been reported from Himalayan region during the southwest monsoon period (Jun - Sep).

A percentile analysis (99.9) of the hourly rain recorded in around 250 SRRG stations of IMD indicates the requirement of a change in the threshold of $100 \mathrm{~mm} / \mathrm{h}$ (as defined by IMD) to classify a cloudburst phenomena. The rare precipitation events in most of the stations along the foothills of Himalayas are between $70-80 \mathrm{~mm} / \mathrm{h}$ (Fig. 3a). The rain rate is also high in Gujarat and Rajasthan, but this could be explained as the data set used for the percentile analysis (hourly rain $>0 \mathrm{~mm}$ ) varied across different regions. The annual average frequency of rain hours (No. of hours with rainfall $>0 \mathrm{~mm}$ ) is greater than 900 hours (equivalent to 38 days of continuous rain) in sub-Himalayan Gangetic planes, Assam and Meghalaya and less than 100 hours (equivalent to 4 days of continuous rain) in extreme western parts of the country. The rain hours decrease, as we move from east to west across Indian region. The annual frequency of hourly rain rate intensities greater than $30 \mathrm{~mm}$ is also highest in northeastern India and sub-Himalayan West Bengal followed by eastern India, Uttarakhand, Punjab, Himachal Pradesh and west coast of India. The area along the foothills of Himalayas has the highest (1\%) contribution of high intensity $(>30 \mathrm{~mm} / \mathrm{h})$ rainfall events as compared to other regions, which also are showing high values of rain rate in Fig. 3a (Ray et al., 2016a). The instances of rain rate $>70 \mathrm{~mm} / \mathrm{h}$ in SRRG stations 
during the period 1970 - 2010, over the Indian Himalayas (Uttarakhand, Himachal Pradesh and Jammu \& Kashmir) is shown in Table 2. The analysis of hourly rainfall indicated only 3-4 instances of recorded rainfall $>100 \mathrm{~mm} / \mathrm{h}$ from 1970 - 2010. Most of the events occurred in the month of Jul and Aug and $80 \%$ of the instances occurred when the total accumulated precipitation on that day was less than $200 \mathrm{~mm}$ and $10 \%$ of the events were a part of a larger synoptic scale driven systems (>200mm/day). The diurnal variation of rainfall for all the instances depicted in Table 1 is shown in Fig. $3 b$ and $3 c$.The events which had accumulated rainfall more than $200 \mathrm{~mm} /$ day (black line) had multiple peaks, while other events had a single major peak of rain rate $>70 \mathrm{~mm} /$ day and lower rain rates in the remaining hours. These instances were unable to include the cloudburst events reported by researchers, media and public (Table 1). The hourly rain rate in most of the events reported in Table1 is not known due to non availability of SRRG data but some of these events had reported accumulated rainfall more than 200mm/day. As suggested by Deoja et al. (1991) whenever the downpour ranges between 200-1000mm/day, intermittent $100-250 \mathrm{~mm}$ precipitation in an hour can occur and thus can be termed as a cloudburst. Doppler weather radar (DWR) data in that region can further substantiate the claim (Ray et al., 2016b). The mismatch between Table 1 and Table 2 emphasizes the need for a cloudburst definition based on more inputs like damage potential and vulnerability to be considered along with the precipitation thresholds for defining a cloudburst event. Several places in the southern rim of the Himalayas are affected by cloudbursts go unreported, due to non availability of an observation or a weather station and/or undetected due to non availability of Doppler weather radar. Analysis of past data thus indicates that isolated occurrence of $>70 \mathrm{~mm} / \mathrm{h}$ precipitation may not cause as much damage, as that caused by continuous precipitation over a period of $24-48$ hours, with intermittent hours of rain rate $>70 \mathrm{~mm} / \mathrm{h}$. Local people affected by 
cloudbursts have also reported normal rains for hours before and after a cloudburst event for many hours (Joshi and Maikhuri, 1997).

Most of the events are found to be reported during monsoon months and further confirming the fact that most of the isolated events of precipitation of $>70 \mathrm{~mm} / \mathrm{h}$ during premonsoon months may not cause destruction amounting to cloudburst but a sustained precipitation $>200 \mathrm{~mm}$ in past 24 hours over a station with intermittent hourly rain $>70 \mathrm{~mm}$ may qualify to be a cloudburst. Thus it is time to reassess and revaluate the IMD definition of associated precipitation of cloudburst $>100 \mathrm{~mm} / \mathrm{h}$ to either $>100 \mathrm{~mm} / 15 \mathrm{~min}$. In addition, multiple cell of cloudburst needs to be negotiated within the event leading to spell precipitation.

\subsection{Cloudbursts and associated precipitation observational analysis}

To investigate associated dynamics of the cloudburst events, few of the cloudburst events as described in Table 1 are discussed comprehensively along with previous studies by other researcher. Out of these cloudburst events vigorous five events chosen are listed in Table 3 for further deliberation. Precipitation received during these cloudbursts are shown in Fig. 4 from TRMM, Fig. S1 from CMORPH daily $0.25^{\circ}$ dataset and Fig. S2 from CMORPH $8 \mathrm{~km}$ gridded observational dataset. From these daily gridded precipitation distributions, it is seen that cloudburst events 2, 3 and 5 show higher precipitation; whereas cloudburst events 1 and 4 show comparatively lesser precipitation. The observational datasets do not capture precipitation intensity associated with the corresponding cloudbursts in the range of $70-100 \mathrm{~mm} / \mathrm{h}$. However, CMORPH $8 \mathrm{~km}$ dataset (Fig. S2) shows higher precipitation distribution than that from the corresponding CMORPH daily precipitation dataset (Fig. S1). Specifically, CMORPH 8km gridded dataset shows corresponding amount of precipitation associated with cloudburst event 5 which is not well represented in CMORPH daily precipitation dataset having lower resolution. 
This can be attributed to better representation of orography in the higher resolution CMORPH datasets providing better representation of precipitation.

Selected five cloudburst events are simulated using the Advanced Research version of the Weather Research Forecast modelling framework (WRF- ARW 3.4.1, Skamarock et al. 2008; Wang et al. 2010). The model was configured with multiple nests $(27 \mathrm{~km} \times 9 \mathrm{~km} \times 3 \mathrm{~km}$ horizontal model resolutions) centered over Leh $\left(34^{\circ} 09^{\prime} \mathrm{N}, 77^{\circ} 34^{\prime} \mathrm{E}\right)$ which was the locale with intense rainfall reports. The model was initialized using the 1 degree resolution NCEP Final Analysis (FNL) field. The microphysics and planetary boundary layer physics schemes used in the model configuration are WRF Single Moment six class cloud scheme and the Yonsei University Scheme (YSU) respectively as used in previous the Leh cloudburst studies (Ashrit 2010, Kumar et al. 2012, Thayyen et al. 2013). Kain Fritsch cumulus scheme (Kain 2004) is used for convection scheme with explicit run for the innermost domain of $3 \mathrm{~km}$. Due to brevity of volume, experimental details of the modelling design and precipitation analysis is presented in very brief here. For elaborated framework and discussions refer articles Chevuturi et al. (2015); Thayyen et al. (2013) etc. Three hourly TRMM rain rate based precipitation fields for cloudburst event 2 are presented in Fig. 5a, 5b and 5c for 05, 06 and $07 \mathrm{Jul} 2005$ respectively. It is seen from the figures that in the observed fields concentrated precipitation maxima zone during the cloudburst events are seen. While investigating these fields in the model simulations we don't find exact location of the precipitation maxima and at times we don't find at all the corresponding higher precipitation within the model environment as reported in these selected five events (since model could not capture precipitation fields in some of the corresponding simulations and hence data is not presented). However in observations, Fig. 5 and Fig. S3-S6, within the time slice cumulative precipitation shown sometimes does match with the 
corresponding cloudburst events outburst. Overall comparisons with the corresponding observations show that there are shifts in positioning and timing of the cloudburst precipitation maxima as reported by various sources at ground. This is one of the crucial limitations of the cloudburst events to get captured in the modelling fields. It is also pertinent to mention it here that in real time observations as well actual positioning and timing of the cloudburst is elusive. Further, significant gaps in the initial fields also might lead to poor performance in models in accurately representing the cloudbursts. This can be the cause and reason of why model misses some of the cloudburst events (temporally and/or spatially) but captures some events very accurately. For example, Leh cloudburst of 2010 was captured very well by the model (Thayyen et al., 2013) but other cloudburst events modelled in here were not. Thus, this remains an important scientific question to assess the cloudburst characterization within the modelling framework. To explain this critical threshold problem associated with cloudburst events, an attempt is made to look into and is explained in the succeeding sections.

Further, in all the gridded precipitation observational datasets temporal and spatial displacement in the peak maxima precipitation associated with the cloudburst occurrences is seen. These elusive peak precipitation maxima remains a challenge while studying the cloudbursts through numerical simulations as the observational datasets cannot be used to verify the model simulated output. Cloudbursts being a much localized phenomenon thus have a limited temporal and spatial extent. Thus, invariably it is as well not possible to capture the cloudburst events in the station observations. This issue is more pronounced in the Himalayas with highly variable orography which may not capture the cloudburst. As the station might be not having hourly precipitation readings and/or precipitation might completely miss the station and occur in the neighbouring region. With this lack of the station data even the observational gridded 
datasets might not capture the event. Though, satellite information might provide indicators of the precipitation events, which are converted into precipitation output. But this satellite information might underestimate the precipitation scaling of these sporadic events.

\subsection{Cloudbursts and large scale forcings}

The large scale forcing in terms of geopotential height at 700, 500 and $200 \mathrm{hPa}$ associated with cloudburst events listed in Table 3 is shown in Fig. 6. Figures show a common feature of low pressure in the lower troposphere, $700 \mathrm{hPa}$, developing over the northern Indian region associated with a cyclonic circulation in all the cloudburst events. This anomalous circulation pattern is mainly associated with the monsoonal flow. Similar circulation pattern was also reported by Chevuturi et al. (2015). This large scale convective forcing may attribute to the enhancement of the localized cloudburst events. But it is to be noted that this anomalous cyclonic circulation is over the central and western region of the India rather than over the region where the cloudburst occurred. It is as well important to note reduced impact of the mid-latitude circulation pattern called the western disturbances (WDs, Dimri et al., 2015). Only in case of cloudburst event 2 , an active WD in the mid- $(500 \mathrm{hPa})$ and upper $(200 \mathrm{hPa})$ level is seen as a trough embedded in the sub-tropical westerly jet (SWJ). This mid- and upper- level trough associated with the WD shows an interaction with the lower level cyclonic circulation to form a combined system. This is a direct consequence of large scale interaction and associated forcing leading to a cloudburst event. Other than the cloudburst event 2, other cloudbursts show a lower pressure region developed in the upper tropospheric region. The anomalous WD interacting with the cyclonic circulation associated with the monsoon may bring break conditions in the monsoon which is associated with higher precipitation incursion over the Himalayas. Other than the cloudburst 2, rest of the cloudbursts show a low pressure over the northern Indian region in 
relation with the SWJ placed above. Yatagai et al. (2012) suggested that the cloudbursts over the Himalayan region are a result of wave energy transport of the jet stream above the region. The wave like motion of the jet stream is clearly visible in the $200 \mathrm{hPa}$ circulation of all the cloudbursts in the Fig. 6. The wave like motion of jet stream results in energy transport from the Caspian Sea towards the north of India. This might be one of the large scale forcings influencing cloudbursts but it is not clear how much it directly impacts the cloudbursts. There are few of the researches highlighting the role of large-scale forcings leading to synoptic scale extreme events leading to flooding in and along the Himalayas, but not linking to mesoscale cloudburst event. Houze Jr et al. (2011) provided comprehensive explanation for summer 2010 Pakistan flood due to anomalous atmospheric conditions. In this event of catastrophic runoff and flooding rainstorms were displaced to the west over the arid and mountainous region. In such event anomalous propagation of Bay of Bengal depression and its moist environment across the subcontinent to the Arabian Sea together with the development of high pressure over the Tibetan Plateau favoured the moisture channel towards the mountain barrier. Webster et al. (2010) have shown the possibility of prediction of such events and associated large scale flow patterns leading to moisture flow over the Pakistan region using weather forecast models. However, predicting exact form of the cloudburst remained elusive. Investigating same event, Lau and Kim (2012) proposed the physical connection of two extreme events i.e., Russian heat wave and Pakistan flood. Hong et al. (2011) have illustrated role of European blocking and mid-latitude interactions leading to early propagation of moisture influx over Pakistan due to Bay of Bengal depression. In similar but another event of heavy deluge over the Uttarakhand, Joseph et al. (2015), proposed the ability of extended range prediction, showing interaction of mid-latitude westerly trough with monsoon depression leading for heavy precipitation. According to 
Chevuturi and Dimri, 2016, merging of WD with monsoon trough acts as a pulsatory extension of monsoon (PEM) over the Uttarakhand Himalayas. Due to this merging an occluded discontinuity forms over the steep Himalayan orography. This discontinuity forms from the cold gradient of the frontal WD in upper troposphere (leading section warmer and trailing section colder) and warmer and more humid monsoon flow in lower troposphere.

OLR is analyzed using NOAA dataset (Fig. 7). Though precipitation analysis and large scale circulation patterns could not able to capture exact indicators of all cloudbursts, say, over the Leh region (specifically cloudburst 1 and 4). But when the OLR data is analyzed, we see lower OLR values observed over the regions in all the cloudburst events. Evolution of these events indicates the clouding developing over the region. According to Das et al. (2006) "cloudbursts in India occur when monsoon clouds associated with low-pressure area travel northward from the Bay of Bengal across the Ganges plains onto the Himalayas and 'burst' in heavy downpours". The cloudburst 6 is primarily got moisture incursion from Bay of Bengal.

But on analysing vertical integrated moisture flux and transport for Leh cloudbursts 1-5, Fig. 8, it is seen that the moisture flow is mainly from the Arabian Sea. Even in case of cloudburst event over Okhimath, the source of moisture is from the Arabian Sea (Shrestha et al., 2015). Yatagai et al. (2012) as well shown that during cloudburst event 5 over Leh, southeasterly flow prevailed which converged the moisture towards and over the Leh region. Rasmussen and House Jr. (2012) comprehensively provided understanding on large scale forcing associated with Leh cloudburst of 4 - 6 Aug 2010. A conceptual model is illustrated demonstrating integrated role of important meteorological element which led to this anomalous event. Low level moisture convergence in southern side of the Himalayas and convective cells in northward of the Himalayas over Tibetan plateau led to such event. 
With these analyses it can be concluded that there might be indicators for the development of cloudbursts within large scale forcings. But as seen there is not always a direct impact of the large scale forcings on the event. This is because, as stated before, that the cloudburst is a much localized event. But if the trigger of such events is not captured in observational or initial and boundary conditions, these will not be accurately simulated or captured in the model simulations at well (which is further discussed later). This is one of the possible reasons for the failure of the models in capturing the cloudburst events. Chaudhuri et al. (2015) showed importance of the presence of the sufficient amount of moisture for the formation of conditions leading to cloudburst. During the study period, a monsoon trough was present over the Indian mainland, which led the moisture from neighbouring Arabian Sea and Bay of Bengal into the Himalayan region.

\subsection{Cloudbursts and Orographic Forcings}

Large scale orographic interactions are proposed by various authors. Barros et al. (2004) have illustrated use of remote sensing information to provide linkages between space-time variability of cloud, precipitation, large scale circulation patterns and topography. It demonstrated the spatial scale forcing ranging from few $\mathrm{km}$ to continental scale and time scale for onset and intraseasonal variability of ISM. Romatschke and Houze Jr. (2011) have shown that along the western Himalayan region precipitation is associated with smaller but highly convective systems. Chiao et al. (2004) while studying over Alps have illustrated importance of dynamical forcing associated with the upslope-induced and near-surface horizontal velocity convergence - induced vertical motion leading to upslope motion with heavy precipitation concentrated over the mountain peaks. Chen et al. (2007) have illustrated role of Tibetan complex terrain in dynamic blocking which enhances stronger water vapour convergence in 
northwest Sichuan region and thus intensifying the local severe storm. While studying role of terrain and landcover on convective systems during ISM, Medina et al. (2010) have shown different interactions over western and eastern Himalayas.

To understand the localized nature of these cloudburst events vertical distribution of some of the important variables along the orographic details are studied. Barros et al. (2004) have provided a schematic framework to define organised formation of leading-line-trailing stratiform mutli convective system (MCS) type structure and this figure is reproduced as Fig. 9. It shows that not only elevation, but especially the spatial arrangement of topographic gradients determine precipitation forming mechanism and associated precipitation. To understand topographic forcings better, modelling based assessment associated with the selected cloudburst events is carried out and is presented in the Fig. $10-13$. As from the above analysis we can note that the large scale forcing usually may not have a very significant impact on the cloudburst phenomenon. So consequently it can be assumed that the cloudbursts must be a result of localized forcings and orographic interactions within the Himalayan ranges. In this sub-section localized forcings and orographic related interactions leading to the cloudburst events are discussed. Thus hypothesis for the cloudburst formation due to localized forcings over mountainous region includes interactions of convective triggering and orographic locking. The lift of a moist air parcel that is initialized by a convective trigger is enhanced along the steep orography. The rapid lifting due to combination of convection and orography results in orographic locking of convectively triggered cell in swift cloud formation which precipitates suddenly causing cloudburst.

Fig. 10 (Fig. S7) shows the vertical distribution of the omega (vertical pressure velocity) and specific humidity along $35.15^{\circ} \mathrm{N}$ latitudinal $\left(77.57^{\circ} \mathrm{E}\right.$ longitudinal) cross section at Leh. Here 
we observe increasing negative omega along the increasing orography of the mountains of Ladhak region and over Leh. This negative omega represents rising vertical pressure velocity indicating rising motion over the region. Such a negative omega over the Leh region is indicative of the rapid lifting as mentioned in the hypothesis above. Further, the higher specific humidity values over the Ladhak region represent the moisture presence. The moisture over the region is due to incursion from mainly the Arabian Sea that was discussed in the previous sub-section. Increased moisture over the region provides the buoyancy to the air which is conducive for lifting conditions. Thus, for cloudburst events within the Himalayas ranges (Leh), there is vertical rising of the moist air parcels (Chevuturi et al., 2015, Shrestha et al., 2015). There was vertical rising motion as there was low level convergence and upper level divergence at a localized level causing the rapid lifting of the moisture.

These observations of lifting of moisture laden air are also represented in Fig. 11 (Fig. S8) based on vertical distribution of perturbation of equivalent potential temperature (EPT) and vertical moisture flux along $34.15^{\circ} \mathrm{N}$ latitudinal $\left(77.57^{\circ} \mathrm{E}\right.$ longitudinal $)$ cross section at Leh. Here the vertical moisture flux shows negative values along the orography and particularly over the Leh region which is indicative of the lifting motion of moist air. It illustrates that as and when moist air moves along the uphill direction, it sheds along the path and mainly limits within the adjacent lower pressure height in the orographic flow. Figures also represent the vertical distribution of the perturbation of the EPT. For the calculation of this perturbation of EPT, EPT of each grid point is subtracted by the area average of the whole domain at each pressure level. The regions of positive perturbations of EPT represent higher temperature and moisture content. These regions correspond to the regions of instability and can be considered as the cause of the thermodynamically induced storms. EPT is a variable that we are using to indicate the 
convective trigger of the cloudbursts. The cloudburst event 1 shows a slow increase in the positive EPT along the orography of the region. Cloudburst events 2 - 5 show higher positive EPT values over Leh and along the orography of the region. Similar high values of EPT were also seen over Ukhimath in model simulated output during the cloudburst event (Chevuturi et al., 2015). The peak of EPT perturbation indicates the sharp increase of instability or potential energy, which is required for the convective cell development. The reduction in the perturbation of EPT results in the decrease of instability. Tompkins (2001) described a similar development of EPT in deep localized convective storms. Orographic precipitation also shows increased EPT as described by Chiao et al. (2004). With a clear increase in the EPT along the slope of Himalayas, it can be concluded that convective storms get subsequently locked by the orography.

To investigate it further, Fig. 12 (Fig. S9) shows the vertical distribution of hydrometeor mixing ratios with cloud liquid and cloud ice mixing ratios along $34.15^{\circ} \mathrm{N}$ latitudinal $\left(77.57^{\circ} \mathrm{E}\right.$ longitudinal) cross section at Leh. The increase in these mixing ratios is indicative of cloud formation over the region. As observed in the figures there is an increase in cloud hydrometeors mixing ratios over Leh except in cloudburst event 1 . Cloudburst event 1 shows formation of the hydrometeors but these are displaced and the values of mixing ratios are lower. Though cloud formation was observed over Leh as an indication of lower OLR values discussed before. These increased mixing ratios of hydrometeors were also discussed by Das et al. (2006). Das et al. (2006) indicated the formation of the hydrometeors as a result of rapid uplifting of the warm and moist air parcel.

Further, to connect with Fig. 9 (Barros et al., 2004), Fig. 13(a) illustrates spatial distribution of model simulated reflectivity associated with cloudburst event of 13 Sep 2012 18UTC simulated using WRF modelling framework with explicit convection scheme (Chevuturi 
et al., 2015). Associated precipitation cloud formations along the valley-ridge cascading formations are attributed to the presence of hydrometeors in the atmosphere with increased reflectivity values. Higher precipitation maxima associated with reflectivity values up to $40 \mathrm{dBZ}$ are well in comparison with the observed DWR reflectivity in Fig. 1b of Chevuturi et al. (2015). Detailed analysis of combined hydrometeor (cloud water, cloud ice, rain water, snow and graupel) mixing ratios and reflectivity at the location of maximum reflectively is shown in Fig. $13 \mathrm{~b}$ and $13 \mathrm{c}$ respectively. It is apt to mention it here that combined hydrometeor mixing ratios provide signature of the cloud formation in the vertical and reflectivity represents the precipitation reflectivity. Thus, from these later two figures it is seen that the cloud formation reached up to $250 \mathrm{hPa}$ to form high cloud tops. Such clouds can be the cumulonimbus (thunderstorm) clouds that are said to be associated with cloudbursts according to Upadhyay (1995).

While simulating the same event using Consortium of Small-scale modelling (COSMO) (Doms and Schaettler, 2002; Steppeler et al., 2003; Baldauf et al. 2011) framework, Shrestha et al. (2015) have shown very interesting results. Fig. 14 represents the capture of positioning and timing of locale cloudburst event maxima precipitation. This exact identification of position and time of cloudburst event gives a confident picture based on modelling effort. To further understand the associated mechanisms behind the extreme precipitation, model based daily accumulated precipitation over the area along the topography is presented in Fig. 14a. Regional position is located along the protruding foothills of the Himalayas with adjacent dissected valleys on either side, which open up towards the southwest. The simulated maximum daily accumulated precipitation is of the order of over $200 \mathrm{~mm} / \mathrm{d}$, Fig. 14b. Here it is interesting to note that in a very short time span precipitation amount peaks. Corresponding meteorological conditions and 
the potential mechanism behind this extreme precipitation led vertical hydrometeor qg values from 5 to $13 \mathrm{~km}$ with peak mixing ratios of $3.5 \mathrm{~g} / \mathrm{kg}$ around $6 \mathrm{~km}$ (Fig. 14c). Transportation of cloud and rain drops reaches up to $11 \mathrm{~km}$ due to strong updraft in the glaciations regime where they exist as super-cooled drops. Due to glaciations regime interactions snow and ice particles extend from 6 to $14 \mathrm{~km}$, with qs peaking nearly to $1 \mathrm{~g} / \mathrm{kg}$ at $10.5 \mathrm{~km}$ and qi peaking to $0.5 \mathrm{~g} / \mathrm{kg}$ at $13 \mathrm{~km}$ height. In glaciations regime graupel-dominated microphysical process takes place on two accounts in model physics: (1) primarily due to riming of snow and freezing of raindrops or (2) due to freezing of raindrops by collision with ice particles. Below the melting level, due to the melting of graupel enough moisture becomes available in the vertical column, and hence intensification of raindrop formation. At this time, a second shallow convective system develops over the ridge line, which also propagates eastwards and eventually dissipates along with the deep convective storm later.

\subsection{Cloudbursts and its understanding with modelling}

There are few researches made to understand dynamical and thermodynamical processes associated with different cloudburst events, apart from the above discussed. Das et al. (2006) studied Shillagarh cloudburst event of 16 Jul 2003 by employing Mesoscale Model 5 version 3.6 (MM5) framework. By configuring it in multiple nested domains with attention to horizontal resolution and cloud microphysics parameterization, a conceptual model for cloudburst event is proposed comprising of development of vertical shear, vertical motion and moisture distribution within its lifecycle. Chevuturi et al. (2015), while simulating 13 - 14 Sep 2012 Ukhimath cloudburst event using WRF model version 3.4.1 with Advance Research WRF dynamical solver (Wang et al., 2010; Skamarock et al., 2008) illustrated role of steep orographic forcings in rapid dynamical lifting with increased convergence of moist air at lower level along the foothill of the 
mountain and rise along the orography to form the updraft zone of the storm. Simulating the same event using COSMO framework (Doms and Schaettler, 2002; Steppeler et al., 2003; Baldauf et al. 2011), Shrestha et al. (2015) have shown three step mechanism associated with the cloudburst event. Kumar et al. (2014) using National Aeronautical and Space Administration (NASA) Unified Weather Research and Forecasting Model (NU-WRF) simulated Leh cloudburst leading to flash flood in the steep edge of the Himalayas. Using coupled land surface and atmosphere model, Kumar et al. (2014) illustrated model storm trailing as a travelling mesoscale squall line with leading convective line trailing stratiform region, and mid-level inflow jet. By employing nested WRF modelling experiment, Thayyen et al. (2012) have established run off associated with Leh cloudburst event 4 - 6 Aug 2010. Sensitivity experiment by using different cloud microphysics parameterization schemes within nested WRF framework while simulated the same Leh cloudburst event, Kumar et al. (2012) have illustrated closer positioning of model precipitation near to the observation. To critically evaluate the cloudburst based on satellite monitoring of precipitation, Mishra and Srinivasan (2013) have proposed a mathematical framework to compare the precipitation during the Kedarnath cloudburst event of $16-17$ Jun 2013. They suggested that rain index based technique is efficient to study heavy precipitation events at finer scale over the Indian Himalaya region. Integrating clustering technique with the numerical weather prediction model outputs, signal formation of cloudburst events can be assessed and used with short lead time for prediction purposes (Pabreja, 2012). Chaudhuri et al. (2015) have provided comprehensive details based on one of the cloudburst study using four nest WRF model and corresponding observations. Using best combinations of parameterization schemes best reproduction of the observed diurnal characteristic associated with the cloudburst 
event is explained. And, stressed the need of assimilating the high resolution measurements within the modelling framework.

\subsection{Cloudbursts and geomorphology}

The lack of ubiquitous local weather stations coverage in the Himalayas causes limitation in quantifying the extreme precipitation vs gradation process, which is vaguely recognized as cloudburst. In the Himalayan terrain, the burst is invariably observed and experienced in the form of flash flood and sudden debris flow accompanied by heavy precipitation. Often, it is the adverse interaction of society, in the form of loss of life and habitat, with the heavy precipitation resulting flash flood and debris flow (Table 1) bring notice to the occurrence of cloudburst and therefore the short term heavy precipitation in uninhabited region remains a gap in the understanding of this natural processes.

It is observed that the bulk of the cloudburst related gradational phenomenon in the western Himalayas are observed between 1000 - $2500 \mathrm{~m}$ topographic range to the south of the Greater Himalayas having $\sim 5000 \mathrm{~m}$ height above mean sea level (Fig. 15). Though there are some notable exceptions in recent past when the region $>3000 \mathrm{~m}$ average height reported cloudburst viz., in case of 6 Aug 2010 Leh cloudburst in the cold desert of Ladakh (Juyal, 2010; Hobley et al., 2012); unconfirmed and debated 2013 cloudburst over the Uttarakhand region in Garhwal Himalaya (Mishra \& Srinivasan, 2013), etc. The attempt has been made to characterize cloudburst occurrence with the direction of the catchment slope (Asthana and Asthana, 2014). To generalize the geomorphology we choose three catchments, which experienced cloud burst in recent past, from varying height range, size and directions (Fig. 15a) in the upper Ganga catchment to understand the role of local topography and drainage pattern. 
The Asi Ganga catchment, drained by rivers Asi Ganga and Kaldi gad, with >25 km long trunk stream flowing between $\sim 3400$ - $1200 \mathrm{~m}$ at an average gradient of $\sim 90 \mathrm{~m} / \mathrm{km}$ (Fig. 15a) experienced a cloudburst on 3 Aug 2012 causing flash flood, debris flow and extensive toe erosion towards lower reaches of the catchment. The slope distribution in the catchment shows higher slopes towards upper catchment along the northeast to southwest trending Kaldi gad and the gentler slope towards lower reaches (Fig. 15b) along the north to south trending Asi Ganga with decreased gradient of $<50 \mathrm{~m} / \mathrm{km}$. The extensive mass wasting due to enhanced runoff during the cloudburst (Gupta et al., 2013) was observed as the bed load and runoff converged from across the catchment along this less rugged zone (Fig. 15b). The pre- and post- cloudburst comparison of satellite imagery clearly shows the extent of debris flow and slope failure along the lower reaches of the Asi Ganga (Fig. 15b). The enhanced discharge at the catchment outlet increases the height of water column of the flash flood and affected a wider area of the slope causing damage to life and property as reported during the event (Gupta et al., 2013). It is important to note that the slope became unstable at the junction of high gradient Kaldi Gad with the Asi Ganga and contributed extensively to the debris and sediment load to the gentler north to south trending stream outlet (Fig. 15b). This characteristic knee bend turn of trunk stream with increasing gradient and closed topography is commonly observed along other catchments affected by cloudbursts in the region. Another smaller catchment along the Bhilangana river, which is frequently affected by cloudburst and associated mass wasting, lies between 800-1800 $\mathrm{m}$, is drained by $>5 \mathrm{~km}$ long seasonal stream having closed valley with high slope (Fig. 15a and 15c). The trunk stream has $>160 \mathrm{~m} / \mathrm{km}$ average gradient knee bend turn near the catchment outlet where several levels of debris fan are preserved. This knee bend stream turn appears like landslide zone on the imagery but the field observation shows the zone is stable, rocky and steep 
slope affected by frequent flooding with high water column and multiple levels of debris fan derived from the freshly eroded quartzite (Fig. 15c). The steep slope of the stream shows multiple channel scars and the varnished level on the slope, marking the flood level (Fig. 15c), suggests progressive migration of high energy runoff. Such large runoff and high flood level is not possible along the seasonal stream unless the catchment is frequented by extreme precipitation, probably cloudbursts, forming multiple levels of debris fans constituted of freshly eroded quartzite from the host rock (Fig. 15c). Unlike, the above closed catchments with knee bend turning trunk stream, the extreme precipitation associated with cloudburst on 8 May, 2016 affected a stretch of southwest facing slope along the Pinder river (Fig. 15a and 15d). The open slope between 1200 - 1800 m height is drained by several small order streams which produced extensive bed rock erosion in the upper slopes and debris flow towards the lower reaches (Fig. 15d). Though the catchment is small but the high precipitation on a high slope with very high stream gradient caused extensive runoff that damaged houses, road sections and foot bridges along the channels.

The other cloudburst during 28 May and 29 June 2016 along Bhilangana river and Nandprayag (Fig. 15) as well as in the Kumaun Himalayas in further east have also occurred between 800-1600 $\mathrm{m}$ topography in closed valleys with high slope. The past occurrence of cloudburst and associated mass wasting in Himalayan terrain (Bist and Sah, 1999; Sah et al., 2003; Juyal, 2010; Hobley et al., 2012; Rana et al., 2012; Gupta et al., 2013; Islam et al., 2014; Bhambhari et al., 2016) are observed in similar geomorphic setup of the closed valley with a narrow outlet. These observations clearly suggest the extreme precipitation remain localize in the close catchments with high slopes and relief and often drained by streams with orthogonal aligned and high stream gradient (Fig. 15a and 15c). The transient extreme precipitation 
produces heavy runoff that causes bed rock erosion in the upper catchment and at the orthogonal stream junctions with identifiable erosional landforms. The orthogonal junctions produced obstruction of runoff that enhances the runoff height and its gradation potential, thereby causing extensive erosion. These debris laden runoff produce extensive debris flow, toe erosion and debris fans/cones with distinct characteristic towards lower catchment with gentler slopes.

\subsection{Cloudbursts and its impacts on society}

The Himalayas as considered to be youngest mountain is tectonically active and hence geologically known to be inherently vulnerable to hazards. In the recent decades fury and vagaries associated with the secondary impacts of cloudburst events are reported across the Himalayan regions (Haritashya et al., 2006). Most of outfall of these catastrophic events leads to deaths of people, cattle, damaged to crop, property, infrastructure etc. 13 Sep 2013 cloudburst over the Ukhimath (Rudraprayag) killed almost 66 people and damaged land and property (Rana et al., 2012). This event also led to associated geomorphological impacts, landslides and flash floods in downstream river basin. Another early morning event on 31 Aug 2001 over the Tehri District (Uttaranchal, India) has killed 07 persons and left several others homeless in Gona village. In the same region a cloudburst on 10 Aug 2002 led to landslides and debris flow (Sah et al., 2003). This led to many landslides leading to disturbed transport sector (Naithani et al. 2002). In 1993 landslides associated with cloudbursts over Kulekhani catchment, Nepal led to several deaths (Dixit, 2003). Gupta and Uniyal (2012) mentioned that Uttarkashi region have structural characteristics that make region vulnerable to landslides. Further, rain events lead to enhanced pore water pressure, increased weight of the rock mass and reduced frictional forces and in such conditions any small instability introduced over the steep terrain may trigger landslides. Andalagan (1996) has extensively provided hazardous role of cloudburst in erosion and 
sedimentation in small catchments in Uttaranchal leading to devastation. As the Himalayan region has a dense network of glacier fed rivers, the valleys associated with the rivers and tributaries sometimes have narrow outlet. According to Gupta and Uniyal (2012) heavy rains in such areas will form temporary lakes due to the natural damming of water. But when the retention capacity of the barrier is exceeded, the accumulated water floods the downstream regions which might be usually considered safe for settlement. These events have led to many flash floods causing serious natural hazards in the Himalayan regions. Examples of floods associated with cloudbursts are Jammu and Kashmir in 1963, Bias River in 1995, Chirgoan, Himachal Pradesh on 11 Aug 1997 (Thakur, 2000), Assi Ganga in 2005, Rudraprayag in 2006, Ukhimath in 2008 and Leh in 2010 (Dimri et al., 2016). Objective evaluations of these floods triggered by these events are still needed. Destruction associated with these subsequent flooding leads to collapsed houses, damaged roads, sweeping away of bridges etc. As per the data published in various national dailies it brings huge losses to the national exchequer (Rana et al., 2013). Gupta et al. (2013) have extensively discussed losses and damages due to 2012 flash flood occurred in Asi Ganga catchment of the Uttarakhand. Joshi (1997) has on average illustrated that each year almost 04 villages come in the grip of cloudbursts with many damages and casualties reported. In case of Leh cloudburst (6 Aug 2010), it triggered debris flow leading to large scale destruction around Leh valley (Juyal, 2010). Using satellite based information, Bhatt et al. (2011) has scanned the post disaster affects due to Leh cloudburst event and mudslides which are common over the unstable slopes of the Himalayas especially over regions with low vegetation as Leh. Asthana and Asthana (2014) have provided very interesting note on increased occurrence of these events over southward facing agricultural land (quaternary deposits) as the landuse. These superficial deposits are less compact, loosely laid on the surface 
of various types of pre-existing landforms. Hobley et al. (2012) have reported about killing of 600 people and devastating more than 60 villages due to the Leh cloudburst of 6 Aug 2010 . Mishra (2015) have proposed interaction of nature's fury and its balanced interaction with mankind in the context of Uttarakhand flood 2013. Kala (2014) has provided rapid unplanned urbanization with increased population and other land use and land cover changes as one of the major cause of increase in severity of the secondary impacts of these heavy precipitation events such as the Kedarnath disaster of 2013. Such changes without proper risk assessment or mitigation processes in place and good disaster warning and management systems make the Himalayan region extremely vulnerable to damages especially with increased population density over these regions. Floods over the Nepal Himalayas related to cloudbursts are also a major concern. Intense consecutive cloudbursts on 19 and 23 Jul 1993, over the Mahabharat range caused floods in the tributaries of the Trisuli, Rapti and Bagmati rivers. This flood was amplified due to associated debris flow and overflowing of a barrage and resulted in a massive destruction including a hydroelectric power plant (Dixit, 2003; Dhital et al., 2003). Major river floods in the Himalayan region are due to the extreme rainfall events which include the Teesta (1968), Alaknanda (1970), Bhagirathi (1978) and Sutlej (1993 and 2000) river valleys (Joshi and Kumar, 2006). The floods related to the cloudbursts over the region are even more devastating due to the slope of the region that enhances the flow of debris along with the flowing waters or sliding land sections. These debris along with sediments may also contain large boulders rolling along the steep aspect of the slope observed in some regions. This debris flow frequent in regions of loose soil and steep slopes escalate the damages that might be caused by just the landslides or flood waters. Further, though it has not occurred in known history, this region is also extremely vulnerable to lake, glacial lake or dammed lake (barrage lake) outburst floods with cloudburst as 
trigger (Raj et al., 2013; Das 2015, Allen et al., 2015). Thus there is a need for proper vulnerability and risk analysis for better disaster warning and management linked to cloudburst events.

\section{Conceptual model of cloudburst}

Based on very few researches and discussion on the cloudbursts, a kind of synthesis conceptual model is proposed for the better understanding of the processes occurring during the cloudburst events over the Indian Himalayan region.

The analysis from Das et al. (2006), Fig. 16a, suggests very primitive exposition of development of cloudburst based on the development of cloudburst limited to factors viz., vertical shear, vertical motion and the moisture distribution. It proposes merging of two convective cells under the influence of mean flow and yielding heavy precipitation due to strong wind shear and intense vertical motion. This merging intensifies the cloudburst mechanism associated with formation of the anvil and subsequently decays as one single large cell. This model though misses out on the role of orographic forcings integrated with convection trigger. Another conceptual model is proposed by Shrestha et al. (2015), Fig. 16b. It suggests that low pressure over and along the Himalayan foothills leads to the formation of low level easterly flow transporting moisture towards the location of cloudbursts. Moisture convergence at the western indentation is observed from the merging of the warmer southerly flow from the Arabian Sea to the low level easterly flow. The potential instability of the air over the region is increased by this moisture. During the day a cap of an inversion layer is observed over and above the ridgeline. A mid-level wind shear forms over the protruding ridges due to the enhancing northwesterly flow and retreating low-level easterly flow which advects the potential unstable layer. This wind shear over the region triggers shallow convection. This active convective system triggers deeper 
convection by moving eastward along another valley and ridge formation causing heavy rainfall due the intensification of graupel formation which has high fall velocities to sediment out rapidly as precipitation. As per the Chevuturi et al. (2015), Fig. 16c, moisture incursion over the region develops convective activity leading to instability in the atmosphere indicated from the high positive vorticity and vertical movement. These regions show an increase in convective available potential energy (CAPE). In such cases, associated high convective inhibition (CIN) is also observed which causes the increasing CAPE to get collected rather than dissipating or releasing. Further, a sudden reduction in the CIN leads to an immediate release of the collected CAPE. Further the thermodynamical processes (CAPE and CIN) in combination with mechanical processes (steep orographic lifting) cause rapid and enhanced ascent of the moisture laden air flow to level of free convection. The ascending air column is capped by divergence in upper troposphere and convergence in the lower levels. According to Chen and Orville (1980), strong convection is formed during convectively unstable atmosphere with associated mesoscale convergence. It is important to draw attention that it still needs to be investigated as regions of cloudbursts are already at around $600 \mathrm{hPa}$. Faster hydrometeor formation is observed due to increase in rate of condensation due to this faster ascent (Roe 2005). Rapidly ascending air flow associated with moisture advection causes the formation of hydrometeors in the mid to upper troposphere associated with heavy clouds. Fig. 16d is Rasmussen and Houza Jr. (2012) conceptual model of Leh cloudburst event. In this study they proposed that the Tibetan Plateau in the north triggered the convective cells over the high terrain during afternoon due to diurnal heating. Due to this heating $500 \mathrm{hPa}$ easterly jet strengthens leading to upscale these cells into MCSs and forces them to move towards Leh in a west- southwestward direction. These MCSs tap moisture from the Ganges Plain (moisture source is from the Arabian Sea and Bay of Bengal) 
while passing through the periphery of the Tibetan Plateau. The MCSs are strengthened due a mid troposphere vortex of the moisture flowing over the Himalayan barrier. In this course of flow MCSs deepen their convection and enhance the precipitation forming mechanism. Their proposed synthesis that these strengthened MCSs extend all over the adjacent terrain causing the rainfall runoff over this adjoining steep terrain to amass. This amassed runoff is drained into the Indus River valley rapidly near Leh. Such a scenario is somewhat not the usual evolution leading to the extreme precipitation. While studying another event of cloudburst within the Indian Himalayas, Chaudhuri et al. (2015), Fig. 15e, suggested that "diurnally generated convective cells" existing over Tibetan Plateau and Madhya Pradesh develop the MCSs that caused the event. Their finding that mid level flow forced MCSs towards the cloudburst site carrying available moisture from the southern part to ascend along the Himalayan orography. Their analysis is somewhat close to the proposed by Rasmussen and Houze Jr. (2012). In most of above concepts, it is suggested that MCSs are uncommon occurrences over the higher altitudes of the Himalayas or the Tibetan Plateau. Either they are moved in over the cloudburst occurrence site leading to flash flood, or rapidly ascending moisture flow from lower levels towards the higher altitudes of Himalayan region. Based on the synthesis and understanding, in the present study it is proposed that firstly there is a strong convective mechanism which triggers the atmospheric instability for formation of deep convective cell(s)/storm(s). This storm sustains due to accumulated available CAPE released after the reduction of high levels of CIN, and gets moisture feed from southern side of the Himalayan wall. Subsequently, these convective storms get locked at one of the sites within cascading valleys and ridges orientations within the mountains region. Once locked at one site, then orographic forcings causes mechanical lifting of the air parcel lead in deepening the storm and form high cumulonimbus clouds which lead to the 
shedding of all the precipitation at the site. This following mechanism is missing in all the earlier concepts provided. In brief, cloudbursts are convectively triggered storms which get locked in the orographic position at one site.

\section{Summary}

Present paper reviews into the cloudburst mechanism and definition so far available. Though there are very few important studies available on the topic, but nowhere a distinct definition either based on either precipitation threshold amount or on mechanism is given. This study tried to justify and provide such insight for researchers for better understanding as far as cloudburst with the southern rim of the Indian Himalayas is concerned.

For large scale support to sustain the moisture for cloudburst event a low pressure system associated with low level easterly over and along the Gangetic plain causes convergence of the moisture over the north-western part of India. Such situation increases potential instability of the air mass along the valley recesses, which is capped by an inversion located above the ridgeline. In addition, strengthening of the north-westerly flow above the ridges supports the lifting of the potentially unstable air over the protruding ridge of the foothills of the Himalayas and triggers shallow convection, which on passing through adjacent folds initiates deep convection. This mechanism provides the initial convective trigger to the convective storms to originate within the deep valley and ridges. Once these storms are formed and flow/forced within the mid level flow they interact with cascading valleys and ridges organisations within the mountainous region. Within this flow and orographic interaction these storms get locked in one of the orographic cavities and thus horizontal flow/movement is restricted. Since there still remains CAPE developing (due to high CIN) and hence this storms deepen in the vertical air column along the cavity slopes and reach as high as of $14 \mathrm{~km}$ in the vertical. With a reduction in CIN the amassed 
CAPE is released suddenly. In this process of vertical rising formation of hydrometeors, high clouds and localised precipitation occurs. This latter finding of convective trigger followed by the orographic locking is necessary for CIN to grow in the form of cloudburst event.

With this understanding, however, more modelling studies with multiple events and radar observations over the region are essential to better understand the full spectrum of these deep convective events over the region. In addition, definition based on the precipitation threshold according to regional differentiation needs to be revisited. Thus it is time to reassess and revaluate the IMD definition of associated precipitation of cloudburst from " $>100 \mathrm{~mm} / \mathrm{h}$ over a geographical region of approximately $20-30 \mathrm{Km}^{2}$ ' to '>100 $\mathrm{mm} / 15 \mathrm{~min}$ over a geographical region of approximately $20-30 \mathrm{Km}^{2}$. In addition, multiple cell of cloudburst needs to be negotiated within the event leading to spell precipitation.

\section{Acknowledgements}

Authors would like to thank National Data Centre, Pune, IMD for SRRG data. Authors also acknowledge the dataset providers and hosts for gridded observational datasets used in this study; MERRA, TRMM, CMORPH, NOAA-OLR and GDAS-FNL datasets. APD acknowledges CSIR, GoI EMR-II funding for the present work.

\section{Note}

As per the Indian law national boundary should be drawn. In the present study few of the figures are taken from the previous simulations and works and hence corresponding data and results are not archived and thus figures are kept as it is due to that limitation.

\section{References}


Allen, S. K., P. Rastner, M. Arora, C. Huggel, and M. Stoffel (2015), Lake outburst and debris flow disaster at Kedarnath, June 2013: hydrometeorological triggering and topographic predisposition, Landslides, 1-13.

Anbalagan, R. (1996), Hazards of Erosion and Sedimentation Due to Cloud Burst in Small Catchments - A case study from Kumaun Himalayas, India, Proceedings of International conference on Ecohydrology of mountainous areas at Kathmandu, Nepal, 433-438.

Asthana, A. K. L., and H. Asthana (2014), Geomorphic control of cloud bursts and flash floods in Himalaya with special reference to Kedarnath area of Uttarakhand, India, International Journal of Advancement in Earth and Environmental Sciences, 2(1), 16-24.

Baldauf, M., A. Seifert, J. Förstner, D. Majewski, M. Raschendorfer, and T. Reinhardt (2011), Operational convective-scale numerical weather prediction with the COSMO model: description and sensitivities, Monthly Weather Review, 139(12), 3887-3905.

Barros, A.P., G. Kim, E. Williams, and S.W. Nesbitt (2004), Probing orographic controls in the Himalayas during the monsoon using satellite imagery, Nat. Hazards Earth Syst. Sci., 4, 29-51.

Bhan S.C., S. Paul, and K.L. Kharbanda (2004), Cloudbursts in Himachal Pradesh, Mausam, 55, $4,712-713$. 
Bhan, S. C., A.K. Devrani, and V. Sinha (2015), An analysis of monthly rainfall and the meteorological conditions associated with cloudburst over the dry region of Leh (Ladakh), India, Mausam, 66(1), 107-122.

Bhambri, R. Mehta, M., Dobhal, D. P., Gupta, A.K., Pratap, B., Kesarwani, K., Verma,A. 2016. Devastation in the Kedarnath (Mandakini) Valley, Garhwal Himalaya, during 16-17 June 2013: a remote sensing and ground-based assessment. Nat Hazards (2016) 80:1801-1822.

Bhandari, R. K. and C. Gupta (1985), Problems of landslides in the Himalayas and future directions. In J. S. Singh (ed.), Environmental Regeneration in Himalaya: Concepts and Strategies, 39-57

Bhatt, C. M., G.S. Rao, P. Manjusree, and V. Bhanumurthy (2011), Potential of high resolution satellite data for disaster management: a case study of Leh, Jammu \& Kashmir (India) flash floods, 2010, Geomatics, Natural Hazards and Risk, 2(4), 365-375, doi:10.1080/19475705.2011.580014

Bist, K. S. and Sah, M. P., 1999. The devastating landslide of August 1998 in Ukhimath area, Rudraprayag district, Garhwal Himalaya. Current Science, 76, 481-484.

Chaudhuri, C., S. Tripathi, R. Srivastava, and A. Misra (2015), Observation-and numericalanalysis-based dynamics of the Uttarkashi cloudburst, Ann. Geophys., 33, 671-686, doi:10.5194/angeo-33-671-2015. 
Chen, C. H., and H.D. Orville (1980), Effects of mesoscale convergence on cloud convection, Journal of Applied Meteorology, 19(3), 256-274.

Chen, J., C. Li, and G. He (2007), A diagnostic analysis of the impact of complex terrain in the Eastern Tibetan Plateau, China, on a severe storm, Arctic, Antarctic and Alpine Research, 39(4), 699-707.

Chevuturi. A. and Dimri A.P.. Investigation of Uttarakhand (India) disaster- 2013 using Weather Research and Forecasting model. Natural Hazards, 82(3), 1703-1726, 2016.

Chevuturi, A., A.P. Dimri, S. Das, A. Kumar, and D. Niyogi (2015), Numerical simulation of an intense precipitation event over Rudraprayag in the central Himalayas during 13-14 September 2012, J. Earth Syst. Sci., 124(7), 1545-1561.

Chiao, S., Y.L. Lin, and M.L. Kaplan (2004), Numerical Study of orographic forcing of heavy precipitation during MAP IOP-2B, Mon. Wea. Rev., 132, 2184-2203.

Das, S. (2005), Mountain weather forecasting using MM5 modelling system, Curr. Sci, 88(6), 899-905.

Das, P. K. (2015), Global warming, glacial lakes and cloud burst events in Garhwal-Kumaon Himalaya: A hypothetical analysis, International Journal of Environmental Sciences, 5(4), 697708. 
Das, S., R. Ashrit, and M. W. Moncrieff (2006), Simulation of a Himalayan cloudburst event, J. Earth Syst. Sci., 115(3), 299-313, doi:10.1007/BF02702044.

Deoja, B., M. Dhital, B. Thapa, and A. Wagner (1991), Mountain Risk Engineering Handbook, Part I\&II. ICIMOD, Kathmandu, Nepal. Pp. 875.

Dhital, M. R. (2003, September), Causes and consequences of the 1993 debris flows and landslides in the Kulekhani watershed, central Nepal. In Proc. 3rd Intl. Conf. Debris-Flow Hazards Mitigation: Mechanics, Prediction and Assessment, edited by: Rickenmann, D. and Chen C.-L., Millpress, Rotterdam, Netherlands (Vol. 2, pp. 931-942).

Dimri V. P., 2013. Uttarakhand has early warning communication in 1894! Current Science, 105(2), 152.

Dimri, A. P., R.J. Thayyen, K. Kibler, ,A. Stanton, S.K. Jain, D. Tullos, and V.P. Singh (2016), A review of atmospheric and land surface processes with emphasis on flood generation in the Southern Himalayan rivers, Science of the Total Environment, 556, 98-115.

Dimri, A. P., D. Niyogi, A. P. Barros, J. Ridley, U. C. Mohanty, T. Yasunari and D. R. Sikka (2015), Western Disturbance: A Review, Reviews of Geophysics, 53, doi:10.1002/2014RG000460. 
Dixit, A. (2003), Floods and Vulnerability: Need to Rethink Flood Management, Natural Hazards, 28(1), 155-179.

Doms, G., and U. Scha“ttler (2002), A description of the nonhydrostatic regional model LM. Part I: Dynamics and numerics. Deutscher Wetterdienst, 134 pp. [Available online at http://cosmomodel.org.]

Done, J., C.A. Davis, and M. Weisman (2004), The next generation of NWP: Explicit forecasts of convection using the Weather Research and Forecasting (WRF) model, Atmospheric Science Letters, 5(6), 110-117 doi:10.1002/asl.72

Gupta, P., \& S. Uniyal (2012), Landslides and Flash Floods Caused by Extreme Rainfall Events/Cloudbursts in Uttarkashi District of Uttarakhand, Journal of South Asian Disaster Studies, 77.

Gupta, V., D.P. Dobhal, and S.C. Vaideswaran (2013), August 2012 cloudburst and subsequent flash flood in the Asi Ganga, a tributary of the Bhagirathi river, Garhwal Himalaya, India, Current Science (00113891), 105(2).

Haritashya, U. K., P. Singh, N. Kumar, and Y. Singh (2006), Hydrological importance of an unusual hazard in a mountainous basin: flood and landslide, Hydrol. Process., 20, 3147-3154, doi: 10.1002/hyp.6397 
Hobley, D.E.J., H.D. Sinclair, and S.M. Mudd (2012), Reconstruction of a major storm event from its geomorphic signature: The Ladakh floods, 6 August 2010, Geology, 40(6), 483-486, doi:10.1130/G32935.1

Hong, C. C., H.H. Hsu, N.H. Lin, and H. Chiu (2011), Roles of European blocking and tropical-extratropical interaction in the 2010 Pakistan flooding, Geophysical Research Letters, $38(13)$.

Houze Jr, R. A., K.L. Rasmussen, S.Medina, S.R. Brodzik, and U. Romatschke (2011), Anomalous atmospheric events leading to the summer 2010 floods in Pakistan, Bulletin of the American Meteorological Society, 92(3), 291-298, doi:10.1175/2010BAMS.3173.1

Huffman G.J., R.F. Adler, D.T. Bolvin, G Gu, E.J. Nelkin , K.P. Bowman , Y. Hong, E.F. Stocker, D.B. Wolff (2007), The TRMM Multi-satellite Precipitation Analysis: Quasi-Global, Multi-Year, Combined-Sensor Precipitation Estimates at Fine Scale, Journal of Hydrometeorology, 8(1):38-55.

IMD, Climatology of the Himalayas and neighbourhood, 2003, Published by India Meteorological Department, NCC, ADGM(r) office, Pune.

Islam, M.A., Chattoraj S.L., Champatiray P.K, 2014. Ukhimath landslide 2012 at Uttarakhand, India: Causes and consequences. Int. Jour. Geomatics and Geosciences, V. 4(3), 544-557. 
Jenamani, R.K., S.C. Bhan, and S.R. Kalsi (2006), Observational/forecasting aspects of the meteorological event that caused a record highest rainfall in Mumbai, Current Science,90,(10),1344-1362.

Joseph, S., A.K. Sahai, S. Sharmila, S. Abhilash, N. Borah, R. Chattopadhyay, A. Kumar (2015), North Indian heavy rainfall event during June 2013: diagnostics and extended range prediction, Climate Dynamics, 44(7-8), 2049-2065, doi:10.1007/s00382-014-2291-5

Joshi, V. (1997), Effects of Cloud Burst in Himalayas ,India. Perspectives of Mountain Risk Engineering in the Himalayan region, Edited by D.K.Agrawal, A,P. Krishna, V,Joshi, K.Kumar amd L.M.S.Palni, Gynodaya Prakashan Nainital, pp. 87 - 110.

Joshi, V. and R.K. Maikhuri (1997), Cloudburst: a Natural Calamity- a Case Study from Garhwal Himalaya, U.P., Jour. Indian Building Congress ,IV(1),207-219.

Joshi, V. and K. Kumar (2006), Extreme rainfall events and associated natural hazards in Alaknanda valley, Indian Himalayan region, Journal of Mountain Science, 3(3), 228-236.

Joyce,R.J., J.E. Janowiak , P.A. Arkin , and P. Xie (2004), CMORPH: A method that produces global precipitation estimates from passive microwave and infrared data at high spatial and temporal resolution, Journal of Hydrometeorology, 5, 487-503. 
Houze, R. A. Jr., K. L. Rasmussen, S. Medina, S. R. Brodzik and U. Romatschke (2011). Anomolous atmospheric events leading to the Summer 2010 floods in Pakistan, Bull. Of Amer. Meteoro. Soc., 291 - 298. Doi.:10.1175/2010BAMS3173.1.

Juyal, N., (2010), Cloudburst-triggered debris flows around Leh, Current Science, 99, 11661167.

Kala, C. P. (2014). Deluge, disaster and development in Uttarakhand Himalayan region of India: challenges and lessons for disaster management. International journal of disaster risk reduction, $8,143-152$.

Kumar M.S., M.S. Shekhar, S.S.V.S. RamaKrishna, M.R. Bhutiyani and A. Ganju (2012), Numerical simulation of cloud burst event on August 05 2010, over Leh using WRF mesoscale model, Nat. Hazards, 62, 1261-1271, doi:10.1007/s11069-012-0145-1.

Kumar, A., R.A Houze Jr., K.L. Rasmussen, and C. Peters-Lidard (2014), Simulation of flash flooding storm at the steep edge of the Himalayas, J. Hydrometeorol.,15,212-228, doi:10.1175/JHM-D-12-0155.1.

Kumar, A., J. Dudhia, R. Rotunno, D. Niyogi, and U.C. Mohanty (2008), Analysis of the 26 July 2005 heavy rain event over Mumbai, India using the Weather Research and Forecasting (WRF) model, Quarterly Journal of the Royal Meteorological Society, 134(636), 1897-1910, doi:10.1002/qj.325. 
Lau, W. K. and K.M. Kim (2012), The 2010 Pakistan flood and Russian heat wave: Teleconnection of hydrometeorological extremes, Journal of Hydrometeorology, 13(1), 392-403, doi:10.1175/JHM-D-11-016.1

Liebmann B, Smith CA (1996) Description of a Complete (Interpolated) Outgoing Longwave Radiation Dataset. Bulletin of American Meteorological Society, 77: 1275-1277.

Medina, S., R.A. Houze Jr., A. Kumar, and D. Niyogi (2010), Summer monsoon convection in the Himalayan region: terrain and land cover effects, Quart. J. Roy. Meteorol. Soc.,136, 593616., doi: 10.1002/qj.601.

Mishra, A. (2015), Cloudburst and landslides in Uttarakhand: A nature's fury?, Mausam, 66, $139-144$.

Mishra, A. and J. Srinivasan (2013), Did a cloud burst occur in Kedarnath during 16 and 17 June 2013?, Current Science, 105(10), 1351-1352.

Naithani, A. K., V. Joshi, and C. Prasad (2002), Investigation on the Impact of Cloudburst in Tehri District, Uttaranchal-31 August 2001, Geological Society of India, 60(5), 573-577

Pabreja, K. (2012), Clustering technique for Interpretation of Cloudburst over Leh, CSI Journal of Computing,1(2). 
Pangtey, Y. P. S., and Joshi, D. R. (1987). Western Himalaya (Vol. 1). S. C. Joshi (Ed.). Gyanodaya Prakashan.

Raj, K. B. G., Remya, S. N., \& Kumar, K. V. (2013). Remote sensing-based hazard assessment of glacial lakes in Sikkim Himalaya. Current Science (Bangalore), 104(3), 359-364.

Rajeevan, M., A. Kesarkar, S.B. Thampi, T.N. Rao, B. Radhakrishna, and M. Rajasekhar (2010), Sensitivity of WRF cloud microphysics to simulations of a severe thunderstorm event over Southeast India, In Annales geophysicae: atmospheres, hydrospheres and space sciences,28,(2),603-619.

Raman, A. (2013), Uttarakhand had early warning communication in 1894!, Current Science, $105(2)$.

Rana, N., Sundriyal, Y. P. and Juyal, N., 2012. Recent cloudburst-induced landslides around Okhimath, Uttarakhand. Current Science 103, 1389-1390.

Rana, N., S. Singh, Y.P. Sundriyal, and N. Juyal (2013), Recent and past floods in the Alaknanda valley: causes and consequences, Current Science,105,(9),1209-1212.

Rasmussen K.L. and R.A. Houze Jr. (2012), A flash flooding storm at the steep edge of high terrain: Disaster in the Himalayas, Bull. Amer. Meteor. Soc., 93, 1713-1724, doi: 10.1175/BAMS-D-11-00236.1. 
Ray, Kamaljit Ray, Kannan, B.A.M , Stella S., Bikram,S ,Sharma, P., Thampi ,S.B. 2016b, Heavy Rains over Chennai and Surrounding Areas As Captured By Doppler Weather Radar during Northeast Monsoon 2015- A Case Study Proc. of SPIE Vol. 9876 98762G-1, doi: 10.1117/12.2239563.

Ray, Kamaljit, Bhan,S. C., and Bandopadhyay, B. K. ,2015, The catastrophe over Jammu and Kashmir in September 2014: a Meteorological observational analysis, Current Science, 109,3, , $580-591$.

Ray,Kamaljit, Warsi,A.H., Bhan,S.C., Jaswal,A.K., 2016a, Diurnal variations in rainfall over Indian region using self recording raingauge data, Current Science, 110(4),682-686.

Rienecker MM, Suarez MJ, Gelaro R, Todling R, Bacmeister J, Liu E, Bosilovich MG, Schubert SD, Takacs L, Kim GK, Bloom S, Chen J, Collins D, Conaty A, da Silva A, Gu W, Joiner J, Koster RD, Lucchesi R, Molod A, Owens T, Pawson S, Pegion P, Redder CR, Reichle R, Robertson FR, Ruddick AG, Sienkiewicz M, Woollen J (2011) MERRA: NASA\&\#39; modernera retrospective analysis for research and applications. Journal of Climate, 24: 3624-3648

Roe, G. H. (2005). Orographic precipitation. Annu. Rev. Earth Planet. Sci., 33, 645-671.

Romatschke, U., and R.A. Houze Jr (2011), Characteristics of precipitating convective systems in the South Asian Monsoon, J. Hydrometeorol., 12, 3-26,doi: 10.1175/2010JHM1289.1. 
Sah, M. P. and R. K. Mazari (2007). An overview of the geoenvironmental status of the Kullu Valley, Himachal Pradesh, India, J. Mt. Sci., 4, 3 - 23.

Sah, M. P., Asthana, A. K. L., \& Rawat, B. S. (2003). Cloud burst of August 10, 2002 and related landslides and debris flows around Budha Kedar (Thati Kathur) in Balganga valley, district Tehri. Himalayan Geology, 24(2), 87-101.

Schomburg, A., V. Venema, F. Ament, and C. Simmer (2012), Application of an adaptive radiative transfer scheme in a mesoscale numerical weather prediction model, Quarterly Journal of the Royal Meteorological Society, 138(662), 91-102.

Semwal, G.and A.P. Dimri (2010), Diagnostic study and numerical simulation of the Bombay (India) Deluge, Natural hazards, 59(1), 17-31, doi:10.1007/s11069-010-9693-4

Shrestha, P., A.P. Dimri, A. Schomburg, and C. Simmer (2015), Improved understanding of an extreme rainfall event at the Himalayan foothills-a case study using COSMO, Tellus A, 67,26031, doi:http://dx.doi.org/10.3402/tellusa.v67.26031

Sikka, D. R., Ray Kamaljit , Chakravarthy, K., Bhan, S. C.,Tyagi,A., 2015, Heavy rainfall in the Kedarnath valley of Uttarakhand during the advancing monsoon phase in June 2013 ,Current Science, 109, 2,353-361. 
Singh, G.S. and Sen, K.K. 1996. Causes and Consequences of Cloudbursts at Kullu districts in the Himachal Himalaya. Himalaya Paryavaran 4 (1): 13 16.

Skamarock, W. C. (2004). Evaluating mesoscale NWP models using kinetic energy spectra. Monthly weather review, 132(12), 3019-3032.

Skamarock, W. C., J. B. Klemp, J. Dudhia, D. O. Gill, D. M. Barker, M. G. Duda, X.-Y. Huang, W. Wang, and J. G. Powers, 2008: A description of the Advanced Research WRF version 3. NCAR Technical Note 475, http://www.mmm.ucar.edu/wrf/users/docs/arw_v3.pdf.

Steppeler, J., G. Doms, U. Schaettler, H. W. Bitzer, A. Gassmann, U. Damrath, and G. Gregoric, 2003: Meso-gamma scale forecasts using the nonhydrostatic model LM. Meteor. Atmos. Phys., 82, 75-96.

Thakur, V.C., 2000: Cloudburst floods and flash floods caused by landslide and debris flow dam failures in the Indian Himalayas. ICIMOD, Newsletter of the International Centre for Integrated Mountain Development, (38), pp.10-11.

Thayyen, R. J., A.P.Dimri, P. Kumar, and G. Agnihotri (2012), Study of cloudburst and flash floods around Leh, India, during August 4-6, 2010, Natural hazards, 65(3), 2175-2204, doi:10.1007/s11069-012-0464-2. 
Tompkins, A.M., 2001: Organization of tropical convection in low vertical wind shears: The role of cold pools. J. Atm. Sc., 58, 1650-1672.

Upadhyay D.S. 1995: Cold Climate Hydrometeorology. New Age International Publication, New Delhi. Pp. 135.

Wang, W., Bruyere, C., Duda, M., Dudhia, J., Gill, D., Lin, H., Michalakes, J., Rizvi, S., Zhang, X., and Beezley, J. 2010: ARW modeling system user's guide. Mesoscale \& Microscale Meteorology Division (version 3), National Center for Atmospheric Research, Boulder, USA.

Webster, P. J., V.E. Toma, and H.M. Kim (2010), Were the 2010 Pakistan floods predictable?, Geophysical research letters, 38(4),doi:10.1029/2010GL046346.

Weisman, M. L., C. Davis, W. Wang, K.W. Manning, and J.B. Klemp (2008), Experiences with 0-36-h explicit convective forecasts with the WRF-ARW model, Weather and forecasting, 23(3), 407-437, doi:10.1175/2007WAF2007005.1

Yatagai, A., H. Nakamura, T. Miyasaka, and K. Okumiya (2012), Meteorological Conditions Related to the August 2010 Flood Event in Ladakh, in the West Himalayas, Geophys. Res. Abs., 14, 12856. 
Zängl, G. (2007), Interaction between dynamics and cloud microphysics in orographic precipitation enhancement: A high-resolution modeling study of two North Alpine heavyprecipitation events, Monthly weather review, 135(8), 2817-2840. 1.

Zängl, G. (2007), To what extent does increased model resolution improve simulated precipitation fields? A case study of two north-Alpine heavy-rainfall events, Meteorologische Zeitschrift,16(5),571-580,doi:10.1127/0941-2948/2007/0237.

\section{List of tables}

Table. 1. Details of cloudburst events reported over the southern rim of the Himalayas.

Table 2. Highest precipitation in a day, highest precipitation in one hour on that particular day and the corresponding hour reported based on Self recording raingage in the southern rim of the Himalayas.

Table 3: List of selected cloudburst events selected for modeling in the present study.

\section{List of figures}

Fig. 1. Topogrphy (shaded, m) of the Indian Himalayas. Circles marked with the number marked on top are the corresponding cloudbursts reported by various researchers and other agencies as shown in Table 1.

Fig. 2. Monthly mean wind circulation (streamlines, knots) based on 1961 - 1990 average for (a) April at $300 \mathrm{hPa}$, (b) April at $100 \mathrm{hPa}$, (c) July at $300 \mathrm{hPa}$ and (d) July at $100 \mathrm{hPa}$.

Fig. 3(a) Percentile analysis (99.9) of precipitation hours during the period 1971-2000, (b) hourly rain rate for all the Dehradun incidences shown in table.1 (two cases with accumulated rainfall greater than $200 \mathrm{~mm}$ are shown in black) and (c) hourly rainrate for all the Jammu 
and Dharamshala incidences shown in table.1 (two cases with accumulated rainfall greater than $200 \mathrm{~mm}$ are shown in black).

Fig. 4: Observed precipitation (mm/day) based on TRMM analysis at $0.25^{\circ}$ resolution during selected cloudburst event 1 on (a) 22Jun2005 (b) 23Jun2005 and (c) 24Jun2005. (d - f) is same as $(\mathrm{a}-\mathrm{c})$, but for cloudburst event 2 on 05, 06 and 07Jul 2005. ( $\mathrm{g}-\mathrm{i})$ is same as $(\mathrm{a}-$ c), but for cloudburst event 3 on 30, 31 Jul20006 and 01Aug2006. (j - 1) is same as (a c), but for cloudburst event 4 on 08, 09 and 10Aug2008. (m - o) is same as (a - c), but for cloudburst event 5 on 04, 05 and 06Aug2010. (Leh is depicted with + sign).

Fig. 5a: Observed rainrate $(\mathrm{mm} / \mathrm{h})$ based on TRMM for selected cloudburst event 2 on 05Jul2005 at (a) 00UTC, (b) 03UTC, (c) 06UTC, (d) 09UTC, (e) 12UTC, (f) 15UTC, (g) 18UTC and (h) 21UTC. (Leh depicted with + sign).

Fig. 5b: Same as Fig. 5a, but for 06Jul2005.

Fig. 5c: Same as Fig. 5a, but for 07Jul2005.

Fig. 6. Geopotential height (shaded; $\times 100 \mathrm{~m}$ ) and wind (vector; $\mathrm{m} / \mathrm{s}$ ) based on MERRA reanalysis for selected cloudburst event 1 on 23Jun2005(00UTC) at (a) $700 \mathrm{hPa}$, (b) $500 \mathrm{hPa}$ and (c) $200 \mathrm{hPa} .(\mathrm{d}-\mathrm{f})$ is same as $(\mathrm{a}-\mathrm{c})$, but for cloudburst event 2 on 06Jul2005 (00UTC). (g i) is same as $(\mathrm{a}-\mathrm{c})$, but for cloudburst event 3 on 31Jul2006 (00UTC). ( $\mathrm{j}-1)$ is same as $(\mathrm{a}-\mathrm{c})$, but for cloudburst event 4 on 09Aug2008 (00UTC). (m - o) is same as (a - c), but for cloudburst event 5 on 05Aug2010 (00UTC). (Leh depicted with + sign).

Fig. 7. Outgoing Longwave Radiation (shaded; $\mathrm{W} / \mathrm{m}^{2}$ ) based on NOAA data for selected cloudburst event 1 on (a) 22Jun2005, (b) 23Jun2005 and (c) 24Jun2005. (d - f) is same as $(\mathrm{a}-\mathrm{c})$, but for cloudburst event 2 on 05, 06 and 07Jul2005. $(\mathrm{g}-\mathrm{i})$ is same as $(\mathrm{a}-\mathrm{c})$, but for cloudburst event 3 on 30, 31Jul2006 and 01Aug2006. (j - k) is same as (a - c), but for 
cloudburst event 4 on 08, 09 and 10Aug2008. ( $\mathrm{m}-\mathrm{o}$ ) is same as (a - c), but for cloudburst event 5 on 04, 05 and 06Aug2010. (Leh depicted with + sign).

Fig. 8: Same as Fig. 7, but for vertical integrated moisture transport ( $\mathrm{kg} / \mathrm{m} / \mathrm{s}$; vector) and flux $\left(\times 10^{-3} \mathrm{~mm}\right.$; shaded) based on MERRA reanalysis. (Leh depicted with + sign).

Fig.9 .Conceptual summary of the spatial distribution of precipitation forming mechanism and associated precipitation obtained in interactions with valley-ridge systems. (Continuous dark lines represent orographic gravity waves; dashed lines represent single-cell mountain valley circulations). (Source: Barros et al., 2004).

Fig. 10: Same as Fig. 7, but for vertical distribution of omega (shaded; $\mathrm{Pa} / \mathrm{s}$ ) and specific humidity (contour; $\times 10^{-3} \mathrm{~g} / \mathrm{kg}$ ) at $34.15^{\circ} \mathrm{N}$ latitude cross section based on MEERA reanalysis.

Fig.11. Same as Fig. 10, but for vertical distribution of perturbation of equivalent potential temperature (EPT) (shaded) and vertical moisture flux (contour; $\mathrm{Pa} / \mathrm{s}$ ). [Vertical moisture flux $=$ Omega $\times$ Specific Humidity

Fig. 12: Same as Fig. 10, but for vertical distribution of cloud liquid water mixing ratio $\left(\times 10^{-3}\right.$ $\mathrm{g} / \mathrm{kg}$; shaded $)$ and cloud ice mixing ratio $\left(\times 10^{-3} \mathrm{~g} / \mathrm{kg}\right.$; contour $)$.

Figure 13. (a) Spatial distribution of model simulated maximum reflectivity (dBZ) with the plus sign depicting Ukhimath and the dotted cross sign showing the location of maxima for maximum reflectivity (at $301949 \mathrm{~N} ; 7928$ 09E), (b) longitude and height distribution (along $301949 \mathrm{~N}$ along the long dashed line from figure 11a) of reflectivity (dBZ; contour) and combined mixing ratio of hydrometeors ( $\mathrm{kg} \mathrm{kg}-1$; shaded), and (c) latitude and height distribution along $792809 \mathrm{E}$ along the short dashed line from figure 11a) of reflectivity (dBZ; contour) and combined mixing ratio of hydrometeors $(\mathrm{kg} \mathrm{kg}-1$; 
shaded) for 13 September 201218 UTC at $3 \mathrm{~km}$ grid spacing with explicit physics. Combined mixing ratio of hydrometeors is the sum of mixing ratios of cloudwater, rainwater, cloudice, snow and graupel. (Source: Chevuturi et al., 2015)

Fig. 14. (a) Modelled accumulated precipitation with the local topography at the resolution of the D2 model domain $(2.8 \mathrm{~km})$. The topography contour interval is $500 \mathrm{~m}$ reaching from 2000 to $6000 \mathrm{~m}$ elevation. (b) Time-series of accumulated precipitation at location marked 'o' (red) and the surrounding grid cells (grey), starting 12 September 2012. The precipitation accumulation shown in the spatial distributions is derived from 0000 UTC to 2330 UTC. (c) (c) Cross-section AA' of hydrometeors (qr in colour shading, qc, qi, qg, qs in solid lines from 0.2 to $2.4 \mathrm{~g} / \mathrm{kg}$ at intervals of $0.4 \mathrm{~g} / \mathrm{kg}$ ), wind vectors and temperature (black contours, showing the melting level). [qx refers to mixing ratio of different hydrometeors, with $x$ being cloud water (qc), cloud ice (qi), graupel (qg), snow (qs) and rain (qr)]. (Source: Shrestha et al., 2015).

Fig. 15. (a) The DEM of upper Ganga catchment in Himalayan terrain overlaid with the contours of 1000, 2000 and $3000 \mathrm{~m}$, past cloud burst locations and the studied catchments. Please note the elevation profile of Asi Ganga river. (b) Slope pattern and Google images of pre- and post- 2 August, 2012 cloudburst clearly showing affected lower stretch of the glacial fed perennial Asi Ganga river catchment, a tributary of the Bhagirathi river . (c) PAN image, slope pattern, profile section and field photograph of the repeated cloud burst affected valley along a rain fed seasonal tributary stream of the Bhilangana river. Note the multiple channel scar and varnished level on the slope marking water level during transient floods. (d) Google image overlaid with the height contours of an open 
steep slope along the Pinder river affected by extreme precipitation on 8th May, 2016. Note the profiles and gradational landform developed during the rain.

Fig. 16. Conceptual diagram leading to cloudburst mechanism over the southern rim of the Indian Himalayas proposed by (a) Das et al. (2006), (b) Shrestha et al. (2015), (c) Chevuturi et al. (2015), (d) Rasmussen and Houze Jr. (2012) and (e) Chaudhuri et al. (2015). 
Table. 1. Details of cloudburst events reported over the southern rim of the Himalayas.

\begin{tabular}{|c|c|c|c|c|c|}
\hline S. No. & $\begin{array}{l}\text { Date and } \\
\text { Time }\end{array}$ & $\begin{array}{c}\text { Location } \\
\text { (Lat./Lon./Alt.) }\end{array}$ & $\begin{array}{l}\begin{array}{c}\text { Precipitat } \\
\text { ion } \\
\text { Reported } \\
(\mathrm{mm} / \mathrm{hr})\end{array} \\
\end{array}$ & $\begin{array}{c}\text { Damage } \\
\text { (Death, loss } \\
\text { of property, } \\
\text { landslides, } \\
\text { flash-flood } \\
\text { etc.) }\end{array}$ & Reference \\
\hline 1 & 20 Jul 1970 & $\begin{array}{c}\text { Ganai- Almora, } \\
\text { Uttarakhand, } \\
29.88^{\circ} \mathrm{N}, 79.35^{\circ} \mathrm{E} \\
1900 \mathrm{~m}\end{array}$ & - & $\begin{array}{l}200 \text { humans, } \\
33 \text { houses }\end{array}$ & $\begin{array}{c}\text { Joshi et.al., } \\
2006\end{array}$ \\
\hline 2 & 17 Jun 1979 & $\begin{array}{l}\text { Saikot- Chamoli, } \\
\text { Uttarakhand, } \\
30.4^{\circ} \mathrm{N}, 79.3^{\circ} \mathrm{E}, \\
2200 \mathrm{~m}\end{array}$ & - & $\begin{array}{c}3 \text { humans, } 70 \\
\text { animals, } 50 \\
\text { houses }\end{array}$ & $\begin{array}{c}\text { Joshi et.al., } \\
2006\end{array}$ \\
\hline 3 & 17 Aug 1979 & $\begin{array}{c}\text { Kuntha- } \\
\text { Rudraprayag, } \\
\text { Uttarakhand, } \\
30.4^{\circ} \mathrm{N}, 79.05^{\circ} \mathrm{E}, \\
1300 \mathrm{~m}\end{array}$ & & $\begin{array}{l}39 \text { humans, } \\
39 \text { animals, } \\
20 \text { houses }\end{array}$ & $\begin{array}{c}\text { Joshi et.al., } \\
2006\end{array}$ \\
\hline 4 & 17 Aug 1979 & $\begin{array}{c}\text { Sirwari- } \\
\text { Rudraprayag, } \\
\text { Uttarakhand } \\
29.9^{\circ} \mathrm{N}, 79.09^{\circ} \mathrm{E} \\
1700 \mathrm{~m} \\
\end{array}$ & - & $\begin{array}{c}13 \text { humans, } \\
150 \text { animals, } \\
34 \text { houses }\end{array}$ & $\begin{array}{c}\text { Joshi et.al., } \\
2006\end{array}$ \\
\hline 5 & 31 Jul 1982 & $\begin{array}{c}\text { Mandakhal Chennil- } \\
\text { Pauri Garhwal, } \\
\text { Uttarakhand, } \\
29.8^{\circ} \mathrm{N}, 78.7^{\circ} \mathrm{E} \\
1700 \mathrm{~m}\end{array}$ & - & $\begin{array}{c}3 \text { humans, } 80 \\
\text { animals, } 8 \\
\text { houses }\end{array}$ & $\begin{array}{c}\text { Joshi et.al., } \\
2006\end{array}$ \\
\hline 6 & 22 Jul 1983 & $\begin{array}{c}\text { Karmi- Kapkote, } \\
\text { Bageshwar, } \\
\text { Uttarakhand } \\
30.1^{\circ} \mathrm{N}, 79.8^{\circ} \mathrm{E}, \\
1981 \mathrm{~m} \\
\end{array}$ & - & $\begin{array}{c}150 \text { humans, } \\
20 \text { animals, } 6 \\
\text { houses }\end{array}$ & $\begin{array}{c}\text { Joshi et.al., } \\
2006\end{array}$ \\
\hline 7 & 09 Jul 1990 & $\begin{array}{l}\text { Nilkanth- Puri } \\
\text { Garhwal, } \\
\text { Uttarakhand, } \\
30.7^{\circ} \mathrm{N}, 78.6^{\circ} \mathrm{E}, \\
1200 \mathrm{~m} \\
\end{array}$ & - & $\begin{array}{c}100 \text { humans, } \\
10 \text { houses }\end{array}$ & $\begin{array}{c}\text { Joshi et.al., } \\
2006\end{array}$ \\
\hline
\end{tabular}




\begin{tabular}{|c|c|c|c|c|c|}
\hline 8 & 16 Aug 1991 & $\begin{array}{c}\text { Dewar Khadora, } \\
\text { Gangolgaon, } \\
\text { Chamoli, } \\
\text { Uttarakhand, } \\
30.4^{\circ} \mathrm{N}, 79.2^{\circ} \mathrm{E}, \\
1600 \mathrm{~m}\end{array}$ & - & $\begin{array}{l}24 \text { humans, } \\
63 \text { animals, } \\
38 \text { houses }\end{array}$ & $\begin{array}{l}\text { Maikhuri and } \\
\text { Joshi, 1997, } \\
\text { Joshi et.al., } \\
2006\end{array}$ \\
\hline 9 & 2 Sept 1992 & $\begin{array}{l}\text { Gadni- Chamoli, } \\
\text { Uttarakhand, } \\
\text { 1900m }\end{array}$ & - & $\begin{array}{l}14 \text { humans, } \\
31 \text { houses }\end{array}$ & $\begin{array}{l}\text { Joshi et.al., } \\
2006\end{array}$ \\
\hline 10 & 13 Aug 1995 & $\begin{array}{c}\text { Bhintai- Pauri } \\
\text { Garhwal, } \\
\text { Uttarakhand, } \\
30.1^{\circ} \mathrm{N}, 78.7^{\circ} \mathrm{E} \\
1300 \mathrm{~m}\end{array}$ & - & $\begin{array}{c}13 \text { humans, } 6 \\
\text { houses }\end{array}$ & $\begin{array}{c}\text { Joshi et.al., } \\
2006\end{array}$ \\
\hline 11 & 17 Jul 1996 & $\begin{array}{c}\text { Berinaga } \\
\text { Pithoragarh, } \\
\text { Uttarakhand, } \\
29.7^{\circ} \mathrm{N}, 80.05^{\circ} \mathrm{E}, \\
2100 \mathrm{~m}\end{array}$ & - & $\begin{array}{l}18 \text { humans, } \\
85 \text { animals, }\end{array}$ & $\begin{array}{l}\text { Joshi et.al., } \\
2006\end{array}$ \\
\hline 12 & $\begin{array}{c}11 \text { to } 19 \text { Aug } \\
1998\end{array}$ & $\begin{array}{c}\text { Okhimath- } \\
\text { Rudraprayag, } \\
\text { Uttarakhand, } \\
30.55^{\circ} \mathrm{N}, 79.21^{\circ} \mathrm{E} \\
1900 \mathrm{~m}\end{array}$ & - & $\begin{array}{l}103 \text { humans, } \\
422 \text { animals, } \\
820 \text { houses }\end{array}$ & $\begin{array}{l}\text { Joshi et.al., } \\
2006\end{array}$ \\
\hline 13 & 18 Aug 1998 & $\begin{array}{c}\text { Malpa- Alaknanda, } \\
\text { Uttarakhand } \\
3000 \mathrm{~m}\end{array}$ & - & $\begin{array}{c}221 \text { humans, } \\
60 \text { animals, } \\
40 \text { houses }\end{array}$ & $\begin{array}{l}\text { Joshi et.al., } \\
2006\end{array}$ \\
\hline 14 & 11 Aug 2001 & $\begin{array}{c}\text { Phata- Rudraprayag, } \\
\text { Uttarakhand } \\
30.57^{\circ} \mathrm{N}, 78.9^{\circ} \mathrm{E} \\
1800 \mathrm{~m} \\
\end{array}$ & - & $\begin{array}{l}27 \text { humans, } \\
64 \text { animals, } \\
22 \text { houses }\end{array}$ & $\begin{array}{l}\text { Joshi et.al., } \\
2006\end{array}$ \\
\hline 15 & 31 Aug 2001 & $\begin{array}{c}\text { Gona, Tehri, } \\
\text { Uttarrakhand } \\
30.36^{\circ} \mathrm{N}, 78.68^{\circ} \mathrm{E},\end{array}$ & 22 & $\begin{array}{c}7 \text { humans, } 7 \\
\text { animals, } 28 \\
\text { houses }\end{array}$ & $\begin{array}{l}\text { Joshi et.al., } \\
2002\end{array}$ \\
\hline 16 & $16 \mathrm{Jul} 2003$ & $\begin{array}{c}\text { Shillagarh, Himachal } \\
\text { Pradesh, } \\
31.5^{\circ} \mathrm{N}, 77^{\circ} \mathrm{E}\end{array}$ & $75-100$ & 35 humans & Das et.al., 2006 \\
\hline
\end{tabular}




\begin{tabular}{|c|c|c|c|c|c|}
\hline 17 & 6 Aug 2010 & $\begin{array}{c}\text { Leh, Jammu \& } \\
\text { Kasmir } \\
34.09^{\circ} \mathrm{N}, 77.34^{\circ} \mathrm{E}\end{array}$ & 23.3 & $\begin{array}{l}255 \text { humans, } \\
1749 \text { houses }\end{array}$ & $\begin{array}{c}\text { Juyal 2010, } \\
\text { Thayyen et.al., } \\
2012, \\
\text { Kumar et.al., } \\
2012, \\
\text { Pabreja et.al., } \\
2012, \\
\text { Kumar et.al., } \\
2013, \\
\text { Bhan et.al., } \\
2014, \\
\text { Bhatt et.al., } \\
2016\end{array}$ \\
\hline 18 & 3 Aug 2012 & $\begin{array}{l}\text { Pandrasu ridge, } \\
\text { Garhwal, Himalaya } \\
\text { Uttarakhand }\end{array}$ & - & $\begin{array}{c}35 \text { humans, } \\
436 \text { livestock } \\
\text { lost, } 591 \\
\text { houses }\end{array}$ & $\begin{array}{l}\text { Gupta et.al., } \\
2013\end{array}$ \\
\hline 19 & 13 Sep 2012 & $\begin{array}{c}\text { Ukhimath, } \\
\text { Rudraprayag, } \\
\text { Uttarakhand } \\
30.5^{\circ} \mathrm{N}, 79.25^{\circ} \mathrm{E}\end{array}$ & 23 & 66 humans & $\begin{array}{c}\text { Rana et.al., } \\
\text { 2012, } \\
\text { Chevuturi } \\
\text { et.al., } 2015\end{array}$ \\
\hline 20 & $\begin{array}{c}\text { 16-17 Jun } \\
2013\end{array}$ & $\begin{array}{c}\text { Badrinath, Gangotri, } \\
\text { Ymunotri and } \\
\text { Kedarnath, } \\
\text { Uttarakhand } \\
30.7^{\circ}-30.8^{\circ} \mathrm{N}, 79^{\circ}- \\
79.1^{\circ} \mathrm{E}\end{array}$ & 25 & $\begin{array}{c}6600 \\
\text { humans, } 365 \\
\text { houses, }\end{array}$ & $\begin{array}{c}\text { Srinivasan } \\
\text { et.al., 2013, } \\
\text { Asthana and } \\
\text { Asthana, } 2014\end{array}$ \\
\hline 21 & 16 Jul 2015 & $\begin{array}{l}\text { Sonamarg, Srinagar, } \\
\text { Jammu \& Kashmir, } \\
34.40^{\circ} \mathrm{N}, 74.71^{\circ} \mathrm{E}\end{array}$ & - & 4 humans & $\begin{array}{c}\text { Indian Express } \\
17 \text { Jul } 2015\end{array}$ \\
\hline 22 & $12 \mathrm{Jul} 2015$ & $\begin{array}{c}\text { Pahalgam, } \\
\text { Anantnag, Jammu \& } \\
\text { Kashmir, } \\
34.01^{\circ} \mathrm{N}, 75.31^{\circ} \mathrm{E}\end{array}$ & - & 2 humans & $\begin{array}{l}\text { PTI, } 13 \text { Jul, } \\
2015\end{array}$ \\
\hline 23 & $17 \mathrm{Jul} 2015$ & $\begin{array}{c}\text { Ganderbal, Jammu \& } \\
\text { Kashmir } \\
34.21^{\circ} \mathrm{N}, 74.77^{\circ} \mathrm{E}\end{array}$ & - & 3 humans & $\begin{array}{c}\text { Daily } \\
\text { Excelsior, } 17 \\
\text { Jul, 2015 } \\
\end{array}$ \\
\hline 24 & $24 \mathrm{Jul} 2015$ & $\begin{array}{c}\text { Baltal, Jammu \& } \\
\text { Kashmir, } \\
34.6^{\circ} \mathrm{N}, 74.7^{\circ} \mathrm{E}\end{array}$ & - & $\begin{array}{l}\text { Not reported } \\
\text { (NR) }\end{array}$ & $\begin{array}{l}\text { PTI 24 Jul } \\
2015\end{array}$ \\
\hline
\end{tabular}




\begin{tabular}{|c|c|c|c|c|c|}
\hline 25 & $28 \mathrm{Jul} 2015$ & $\begin{array}{c}\text { (a) Choskore village } \\
\text { Kargil, J \& K } \\
34.19^{\circ} \mathrm{N}, 76.35^{\circ} \mathrm{E} \\
\\
\text { (b) Wakha villages, } \\
\text { Kargil, J \& K, } \\
34.16^{\circ} \mathrm{N}, 77.6^{\circ} \mathrm{E} \\
\end{array}$ & - & 20 houses & $\begin{array}{c}\text { Kashmir Life, } \\
\text { Greater } \\
\text { Kashmir, 29 Jul } \\
2015\end{array}$ \\
\hline 26 & $25 \mathrm{Jul} 2015$ & $\begin{array}{c}\text { Jibhi village } \\
\text { Banjar Division } \\
\text { Kullu } \\
\text { Tandi Nullah } \\
31.63^{\circ} \mathrm{N}, 77.34^{\circ} \mathrm{E}\end{array}$ & - & NR & $\begin{array}{l}\text { The Times of } \\
\text { India, } 25 \text { Jul } \\
2015\end{array}$ \\
\hline 27 & $\begin{array}{c}22 \mathrm{Jul}, \\
28 \mathrm{Jul}, \\
9 \text { Aug } 2015\end{array}$ & $\begin{array}{c}\text { Biama, Leh, } \\
\text { Jammu \& Kashmir } \\
34.15^{\circ} \mathrm{N}, 77.57^{\circ} \mathrm{E}\end{array}$ & - & $\begin{array}{c}\text { office-cum- } \\
\text { residence of } \\
\text { Water and } \\
\text { Power } \\
\text { Consultancy } \\
\text { Services } \\
\text { (WAPCOS) } \\
\text { damage }\end{array}$ & $\begin{array}{l}\text { Kashmir Life } \\
10 \text { Aug } 2015\end{array}$ \\
\hline 28 & 4 Aug 2015 & $\begin{array}{l}\text { Upper Ganglass, } \\
\text { Saboo,etc. Leh, } \\
\text { Ladakh, } \\
\text { J \& K } \\
34.31^{\circ} \mathrm{N}, 77.53^{\circ} \mathrm{E}\end{array}$ & & NR & $\mathrm{NIH}$ \\
\hline 29 & 8 Aug 2015 & $\begin{array}{c}\text { Dharampur, Mandi, } \\
\text { Himachal Pradesh } \\
31.7^{\circ} \mathrm{N}, 76.7^{\circ} \mathrm{E}\end{array}$ & - & 5 humans & $\begin{array}{c}\text { Tribune, } 8 \text { Aug } \\
2015\end{array}$ \\
\hline 30 & 28 May 2016 & $\begin{array}{l}\text { (a) Kemra, Kothiara, } \\
\text { Tehri Uttarakhand, } \\
30.57^{\circ} \mathrm{N}, 78.68^{\circ} \mathrm{E}, \\
\text { (b) Siliara, Kothiara, } \\
\text { Tehri Uttarakhand, } \\
30.46^{\circ} \mathrm{N}, 78.62^{\circ} \mathrm{E},\end{array}$ & - & $\begin{array}{l}120 \text { houses, } \\
100 \text { animals }\end{array}$ & $\begin{array}{l}\text { Millennium } \\
\text { post, } \\
29 \text { May } 2016\end{array}$ \\
\hline
\end{tabular}


Table 2. Highest precipitation in a day, highest precipitation in one hour on that particular day and the corresponding hour reported based on Self recording raingage in the southern rim of the Himalayas.

\begin{tabular}{|c|c|c|c|c|c|c|}
\hline Stations & Date & Month & Year & $\begin{array}{l}\text { Total } \\
\text { precipita } \\
\text { tion in } \\
\text { past } 24 \\
\text { hour in } \\
\text { mm }\end{array}$ & $\begin{array}{l}\text { Highest } \\
\text { hourly } \\
\text { precipitation } \\
\text { in } \mathbf{m m}\end{array}$ & $\begin{array}{l}\text { Hour of } \\
\text { highest } \\
\text { precipit } \\
\text { ation }\end{array}$ \\
\hline Dehradun & 31 & 07 & 2010 & 185.4 & 74.8 & 0 \\
\hline Dehradun & 10 & 08 & 2008 & 116.2 & 97.0 & 14 \\
\hline Dehradun & 31 & 07 & 2007 & 161.6 & 70.0 & 20 \\
\hline Dehradun & 02 & 08 & 2006 & 105.1 & 72.5 & 14 \\
\hline Dehradun & 02 & 06 & 2001 & 134.9 & 70.2 & 4 \\
\hline Dehradun & 22 & 09 & 1999 & 98.4 & 84.3 & 7 \\
\hline Dehradun & 14 & 07 & 1997 & 181.2 & 72.4 & 0 \\
\hline Dehradun & 22 & 08 & 1993 & 127.0 & 70.0 & 19 \\
\hline Dehradun & 25 & 07 & 1992 & 98.8 & 71.3 & 20 \\
\hline Dehradun & 11 & 7 & 1975 & 84 & 71.5 & 4 \\
\hline Dehradun & 24 & 7 & 1973 & 315.5 & 74 & 9 \\
\hline Dehradun & 23 & 7 & 1973 & 128.2 & 72 & 0 \\
\hline Dehradun & 20 & 7 & 1973 & 98.2 & 76.6 & 22 \\
\hline Dehradun & 8 & 6 & 1971 & 156.2 & 75.5 & 3 \\
\hline Dehradun & 5 & 7 & 1970 & 113.9 & 75 & 20 \\
\hline Dehradun & 14 & 6 & 1970 & 289.2 & 101.1 & 10 \\
\hline Dehradun & 7 & 7 & 1969 & 125.5 & 72.7 & 7 \\
\hline Shimla & 17 & 02 & 1988 & 0.0 & 96.1 & 11 \\
\hline Shimla & 11 & 02 & 1988 & 183.4 & 77.0 & 13 \\
\hline Jammu & 02 & 09 & 2003 & 106.1 & 73.5 & 0 \\
\hline Jammu & 13 & 07 & 1988 & 111.5 & 97.5 & 2 \\
\hline Jammu & 17 & 07 & 1984 & 119.9 & 78.5 & 5 \\
\hline Jammu & 02 & 09 & 2003 & 106.1 & 73.5 & 0 \\
\hline Dharamshala & 4 & 8 & 1975 & 113.1 & 72.5 & 21 \\
\hline Dharamshala & 25 & 7 & 1980 & 131.4 & 70 & 0 \\
\hline Dharamshala & 26 & 7 & 1983 & 354.5 & 191.2 & 10 \\
\hline Dharamshala & 14 & 7 & 1985 & 157 & 78 & 10 \\
\hline Dharamshala & 14 & 8 & 1991 & 236.6 & 86 & 20 \\
\hline Dharamshala & 2 & 8 & 1995 & 180.2 & 74 & 4 \\
\hline
\end{tabular}


Table 3: List of selected cloudburst events selected for modeling in the present study

\begin{tabular}{|l|l|l|l|}
\hline Cloudburst Events & Termed as & Dates Studied & Location \\
\hline 23-24 Jun 2005 & Cloudburst 1 & 22Jun2005, 23Jun2005, 24Jun2005 & Leh \\
\hline 06 Jul 2005 & Cloudburst 2 & 05Jul2005, 06Jul2005, 07Jul2005 & Leh \\
\hline 30-31 Jul, 01 Aug 2006 & Cloudburst 3 & 30Jul2006, 31Jul2006, 01Aug2006 & Leh \\
\hline 09 Aug 2008 & Cloudburst 4 & 08Aug2008, 09Aug2008, & Leh \\
& & 10Aug2008 & \\
\hline 04-06 Aug 2010 & Cloudburst 5 & 04Aug2010, 05Aug2010, & Leh \\
& & 06Aug2010 & \\
\hline
\end{tabular}




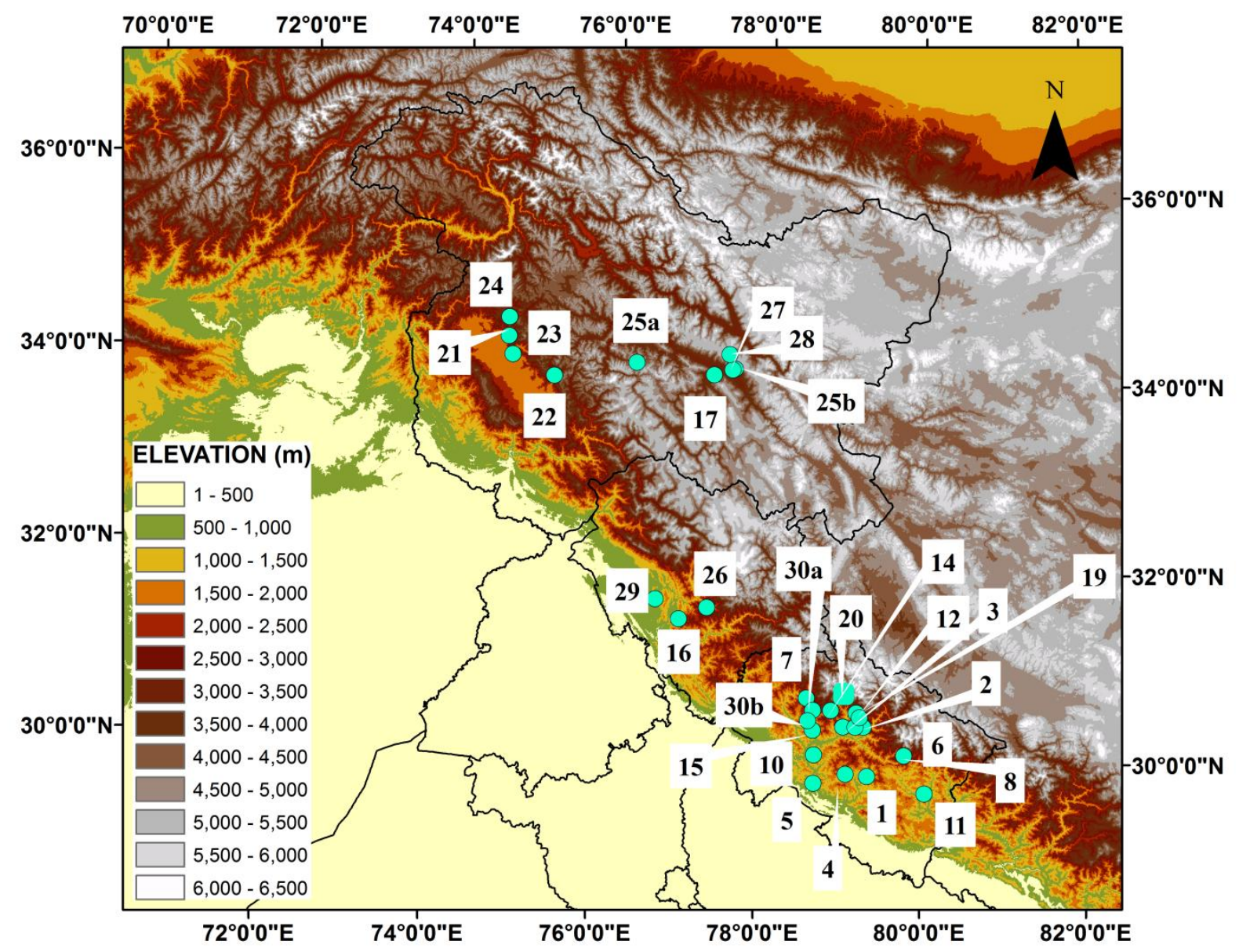

Fig. 1. Topogrphy (shaded, $\mathrm{m}$ ) of the Indian Himalayas. Cirles marked with the number marked on top are the corresponding cloudbursts reported by various researchers and other agencies as shown in Table 1. 
(a)

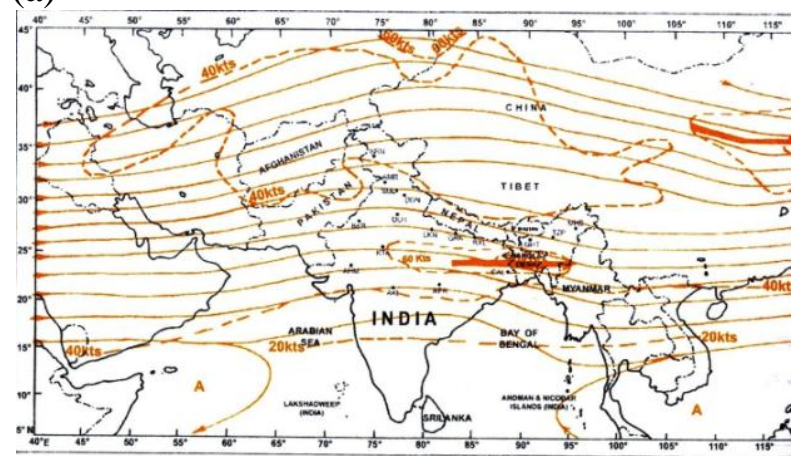

(b)

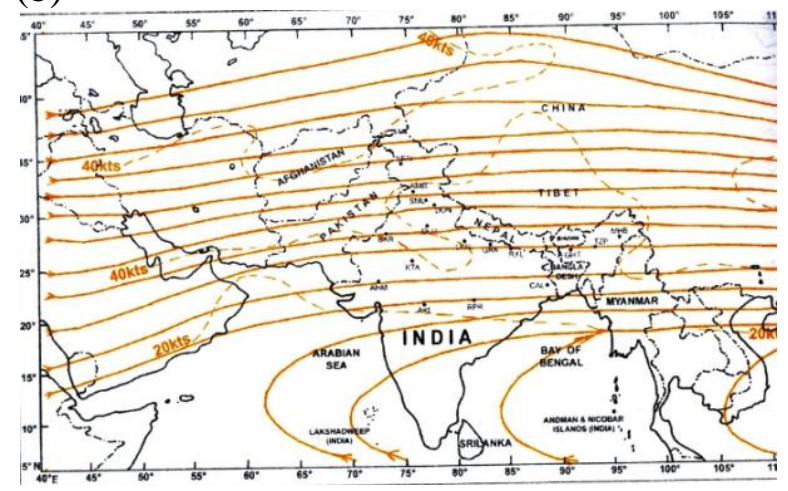

(c)

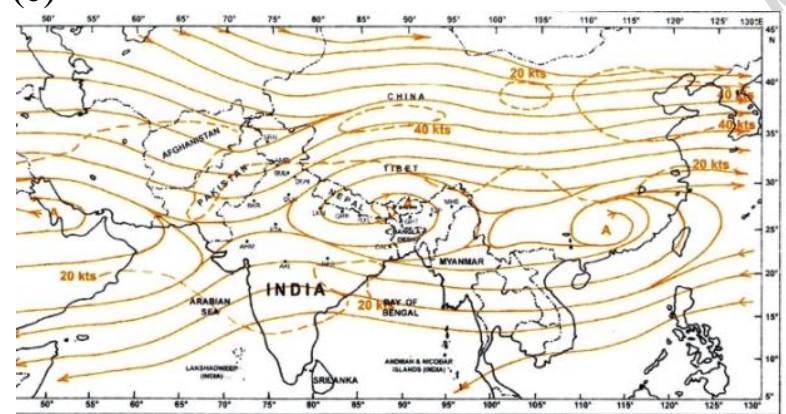

(d)

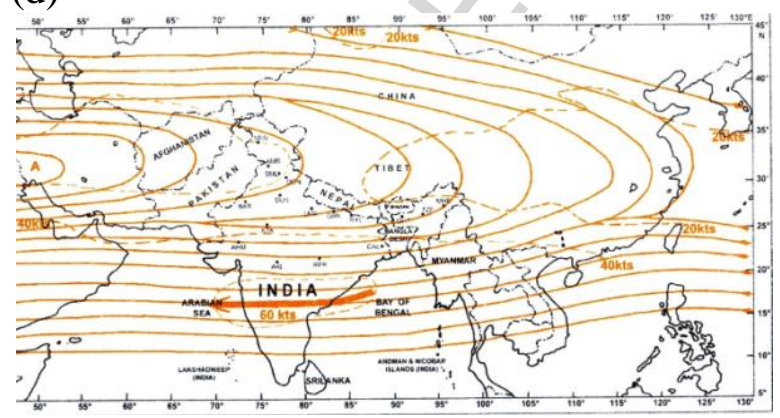

Fig. 2. Monthly mean wind circulation (stremlines, knots) based on 1961 - 1990 average for (a) April at $300 \mathrm{hPa}$, (b) April at $100 \mathrm{hPa}$, (c) July at $300 \mathrm{hPa}$ and (d) July at $100 \mathrm{hPa}$. 
(a)

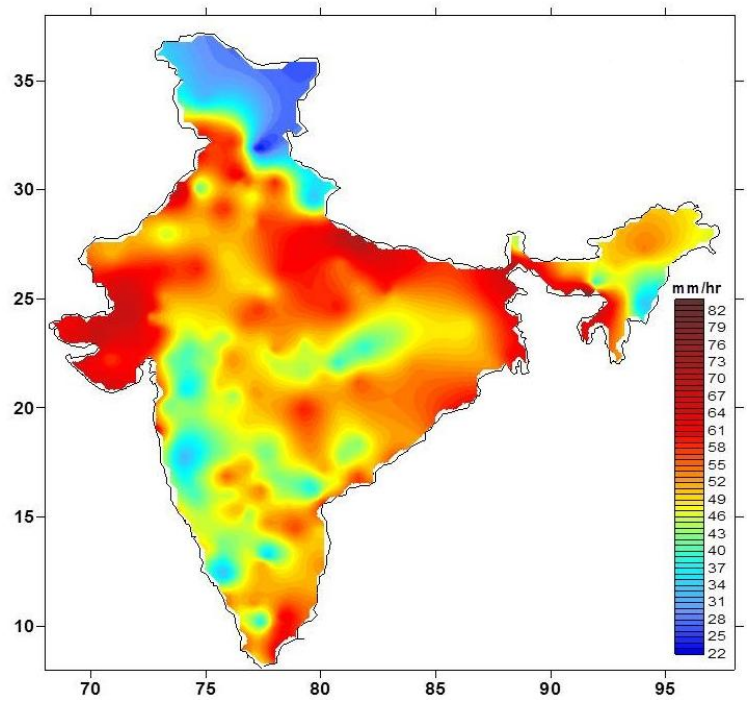

(b)

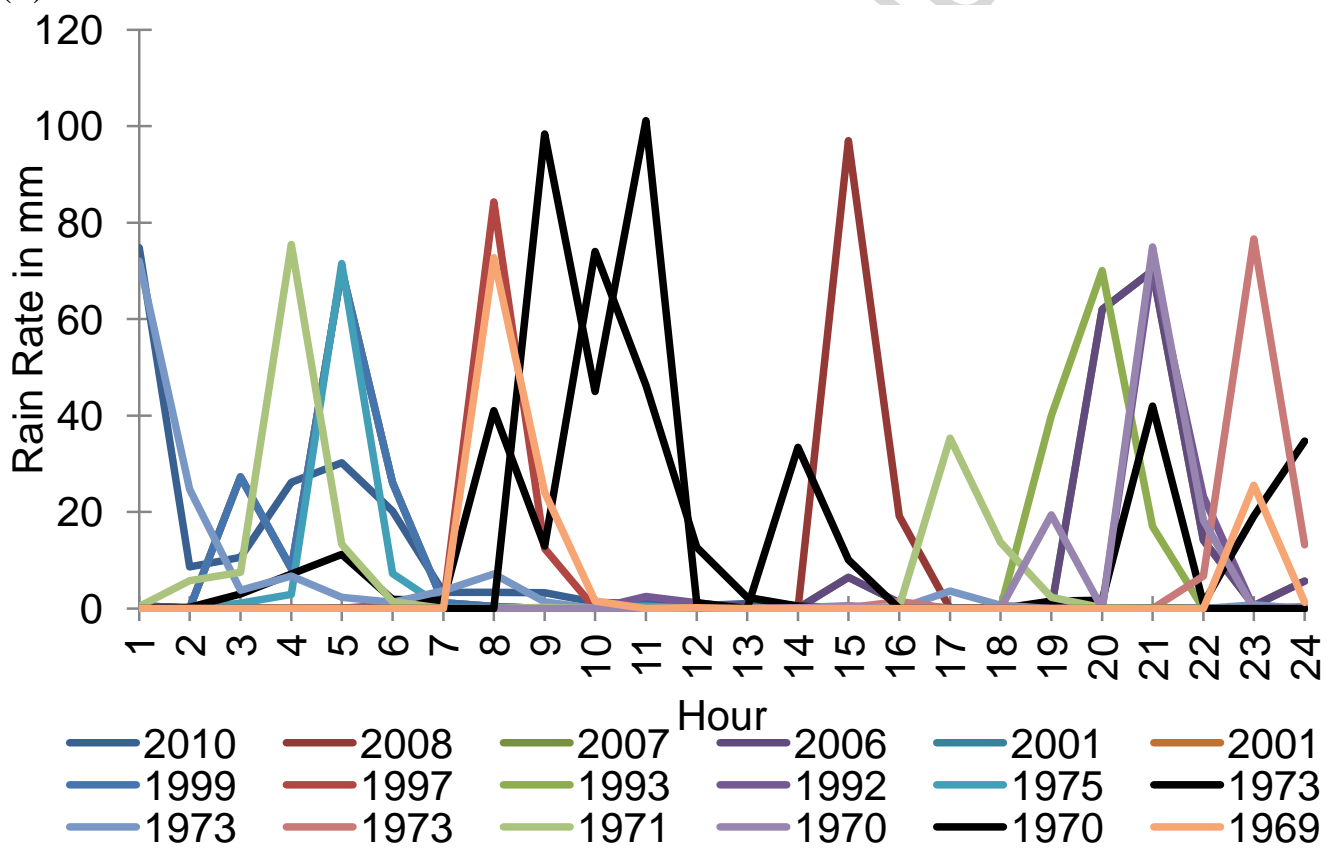


(c)

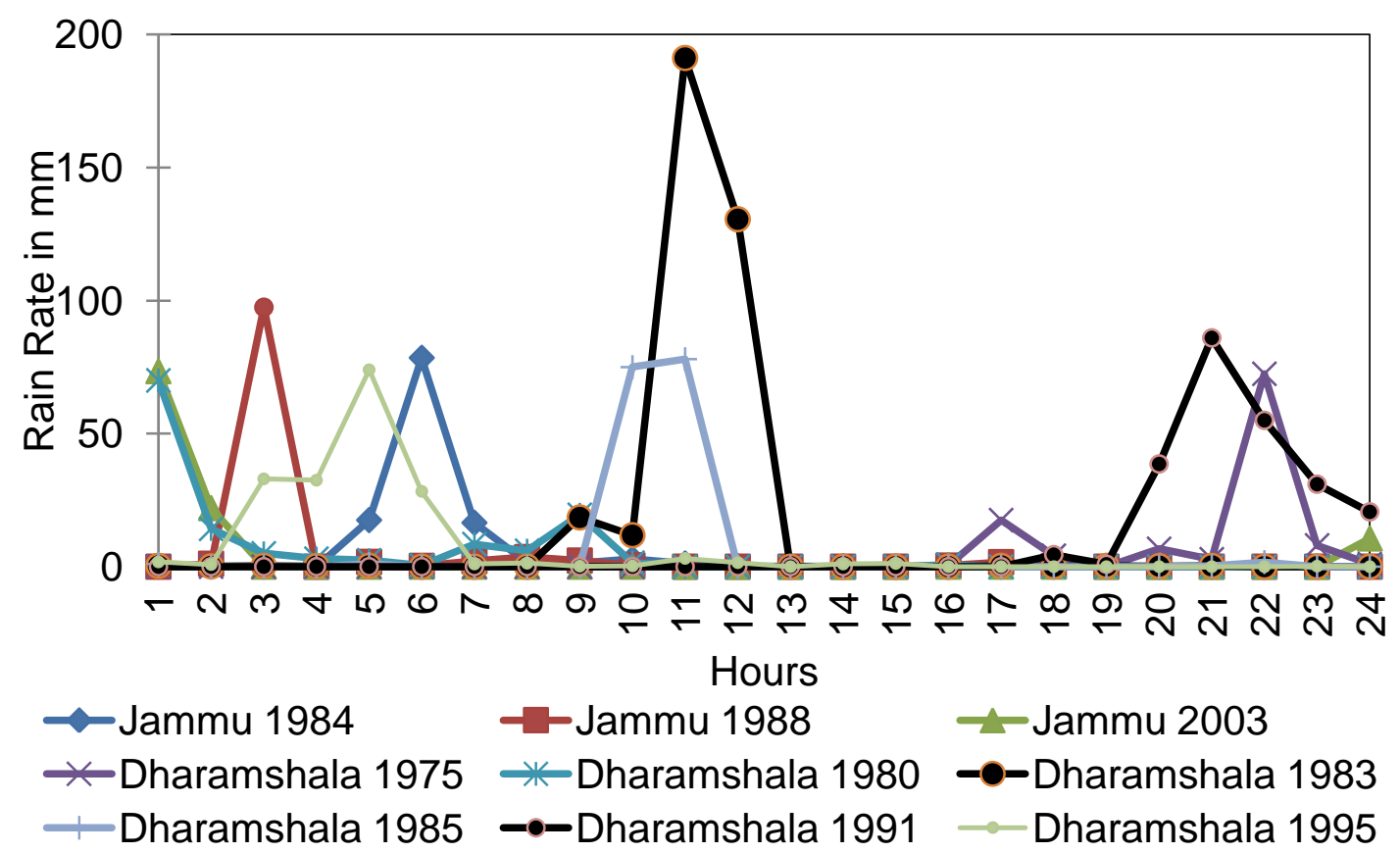

Fig. 3(a) Percentile analysis (99.9) of precipitation hours during the period 1971-2000, (b) hourly rain rate for all the Dehradun incidences shown in table.1 (two cases with accumulated rainfall greater than $200 \mathrm{~mm}$ are shown in black) and (c) hourly rainrate for all the Jammu and Dharamshala incidences shown in table.1 (two cases with accumulated rainfall greater than $200 \mathrm{~mm}$ are shown in black) 


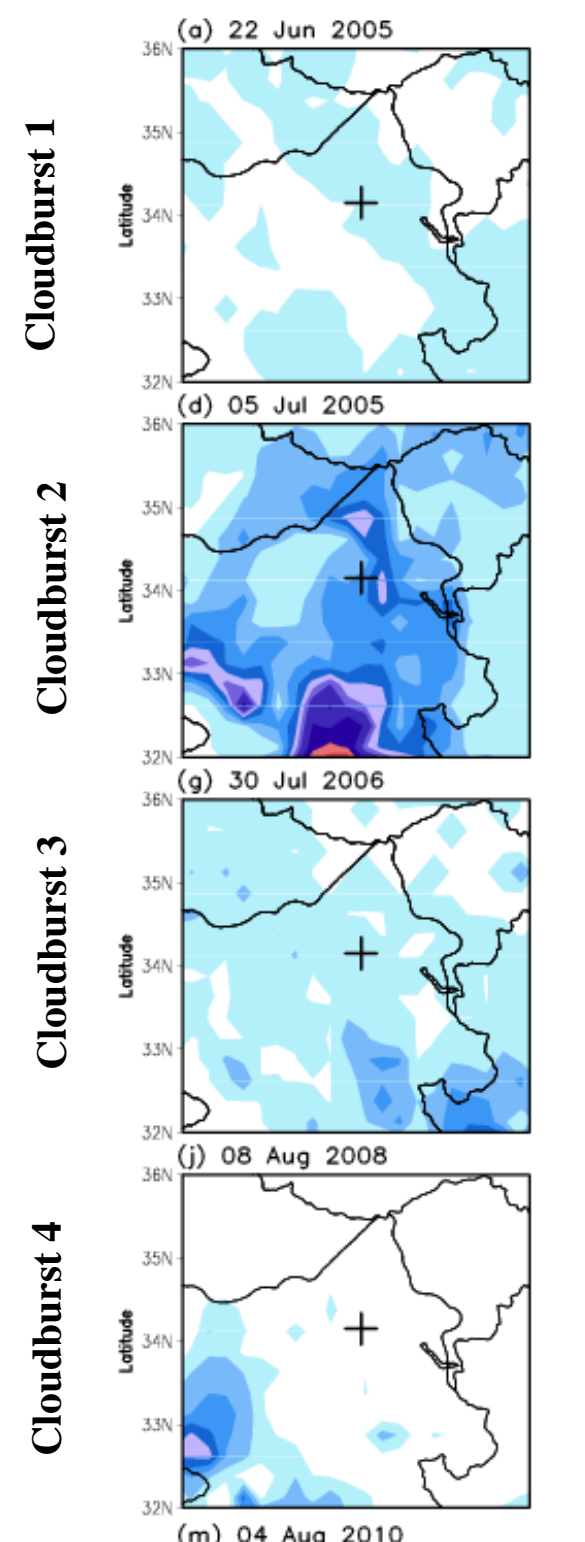

(b) 23 Jun 2005

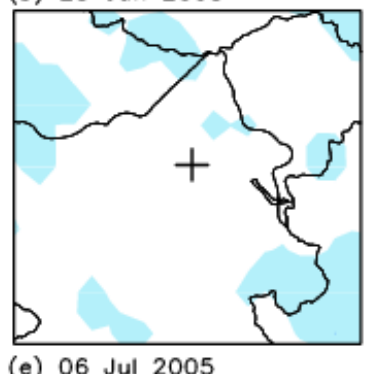

(e) 06 Jul 2005

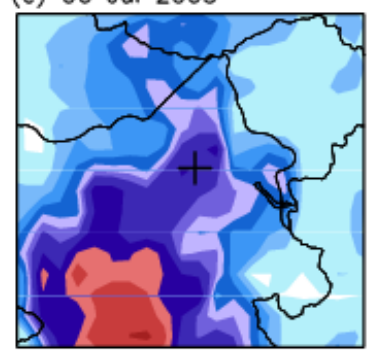

(h) 31 Jul 2006

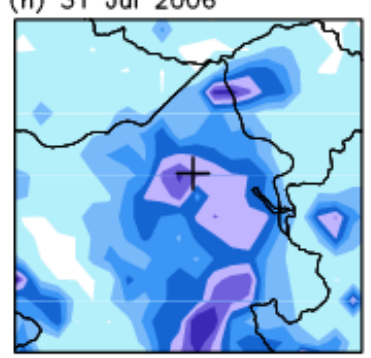

(k) 09 Aug 2008

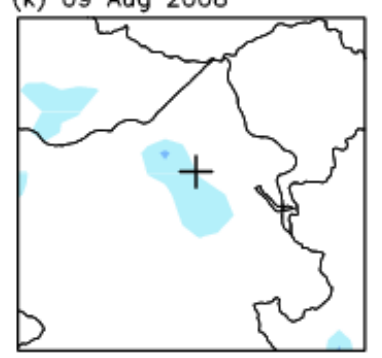

(n) 05 Aug 2010

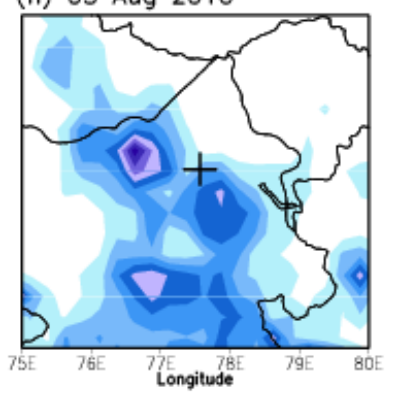

(c) 24 Jun 2005

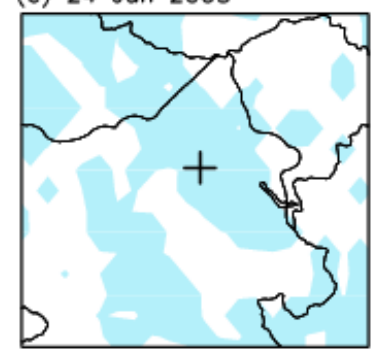

(f) 07 Jul 2005

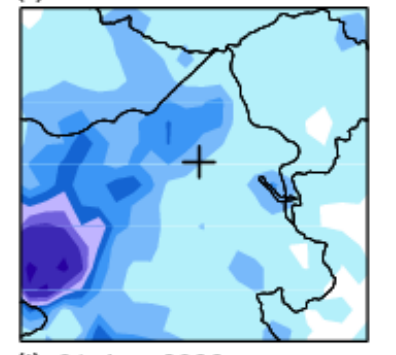

(i) 01 Aug 2006

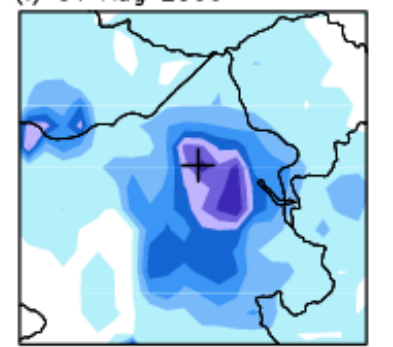

(1) 10 Aug 2008

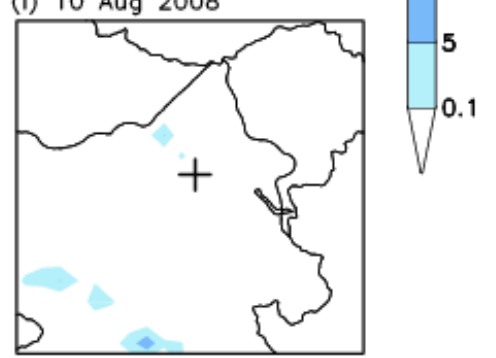

(o) 06 Aug 2010

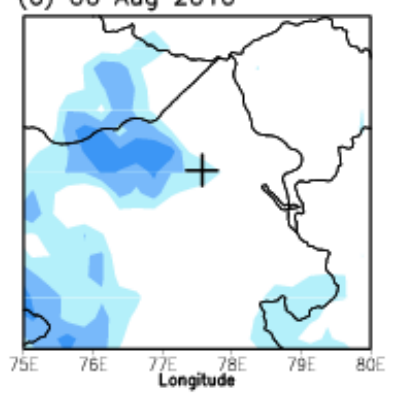

Fig. 4. Observed precipitation (mm/day) based on TRMM analysis at $0.25^{\circ}$ resolution during selected cloudburst event 1 on (a) 22Jun2005 (b) 23Jun2005 and (c) 24Jun2005. (d - f) is same as $(\mathrm{a}-\mathrm{c})$, but for cloudburst event 2 on 05, 06 and 07Jul 2005. ( $\mathrm{g}-\mathrm{i})$ is same as $(\mathrm{a}-\mathrm{c})$, but for cloudburst event 3 on 30, 31 Jul20006 and 01Aug2006. $(\mathrm{j}-1)$ is same as $(\mathrm{a}-\mathrm{c})$, but for cloudburst event 4 on 08, 09 and 10Aug2008. ( $\mathrm{m}-\mathrm{o}$ ) is same as $(\mathrm{a}-\mathrm{c})$, but for cloudburst event 5 on 04,05 and 06Aug2010. (Leh is depicted with + sign). 

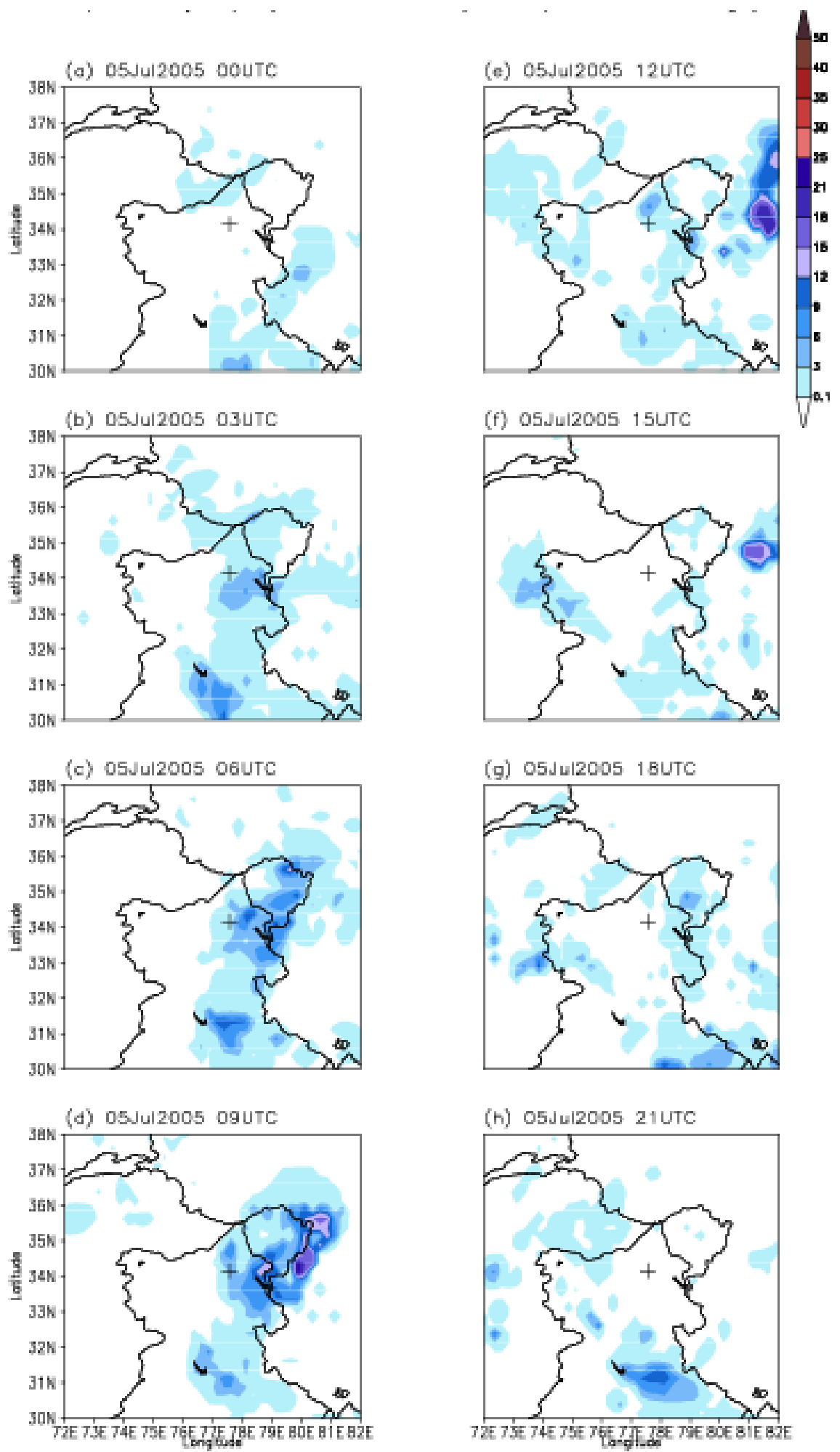

Fig. 5a. Observed rainrate $(\mathrm{mm} / \mathrm{h})$ based on TRMM for selected cloudburst event 2 on $05 \mathrm{Jul} 2005$ at (a) 00UTC, (b) 03UTC, (c) 06UTC, (d) 09UTC, (e) 12UTC, (f) 15UTC, (g) 18UTC and (h) 21UTC. (Leh depicted with + sign). 

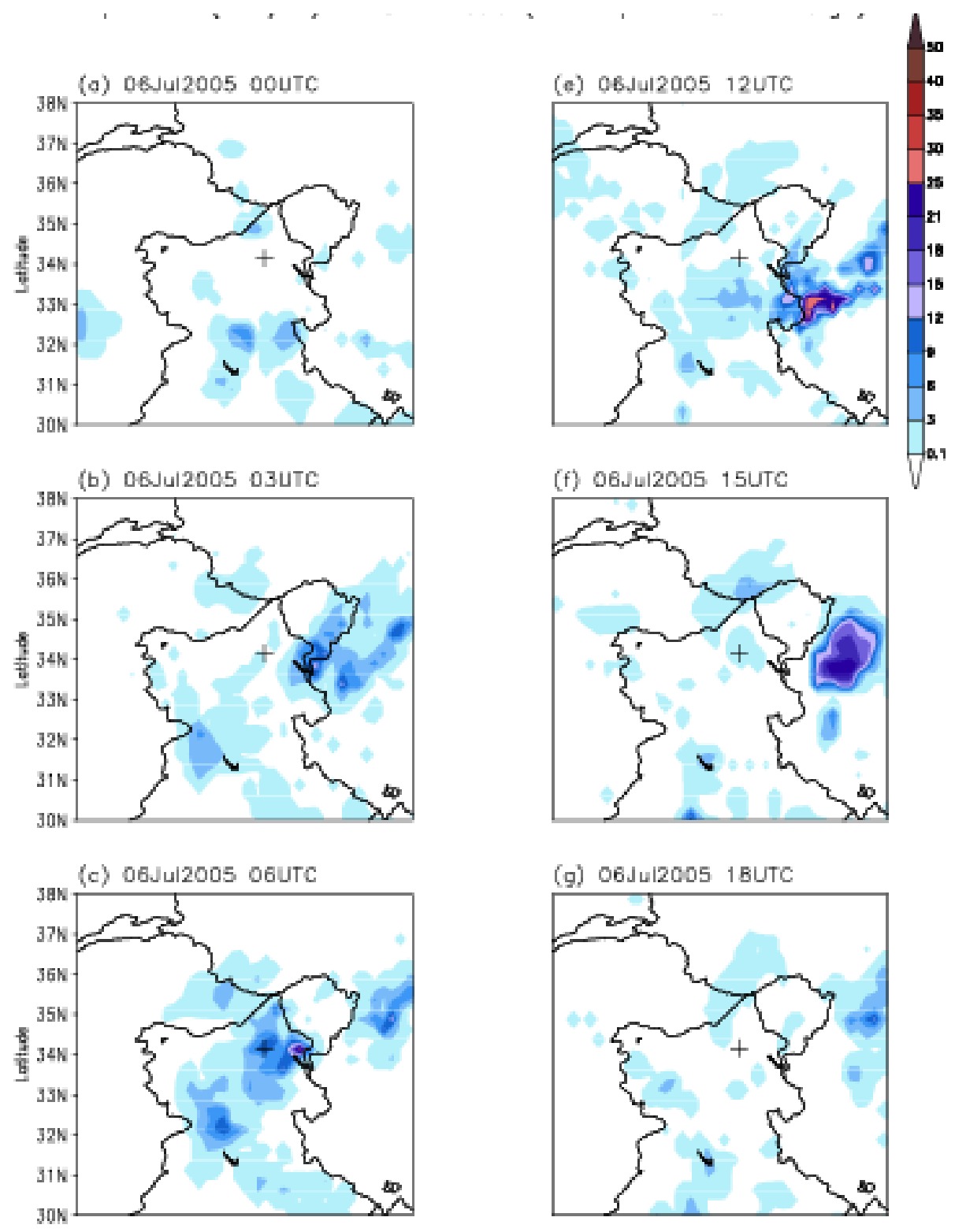

(g) O6Jul2005 1BUTC
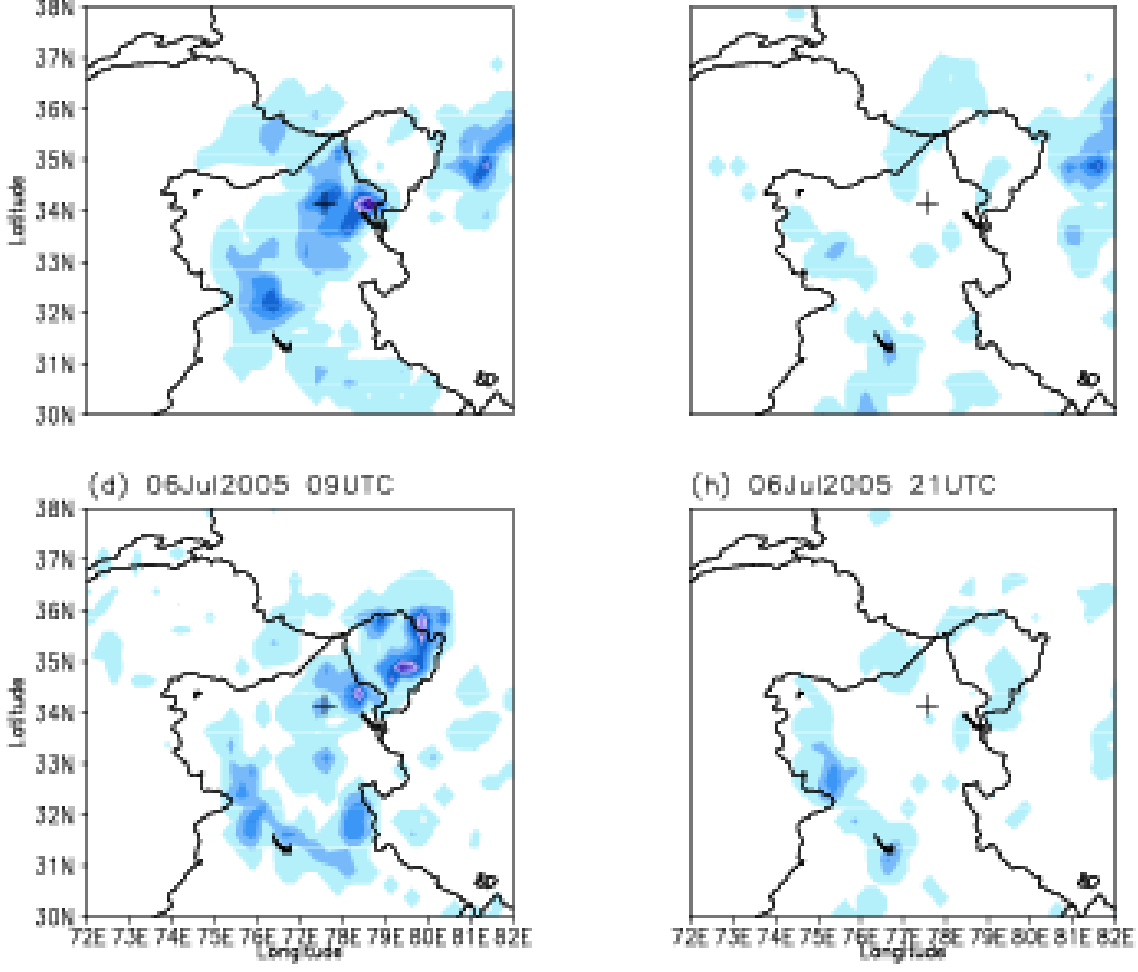

Fig. 5b. Same as Fig. 5a, but for 06Jul2005. 

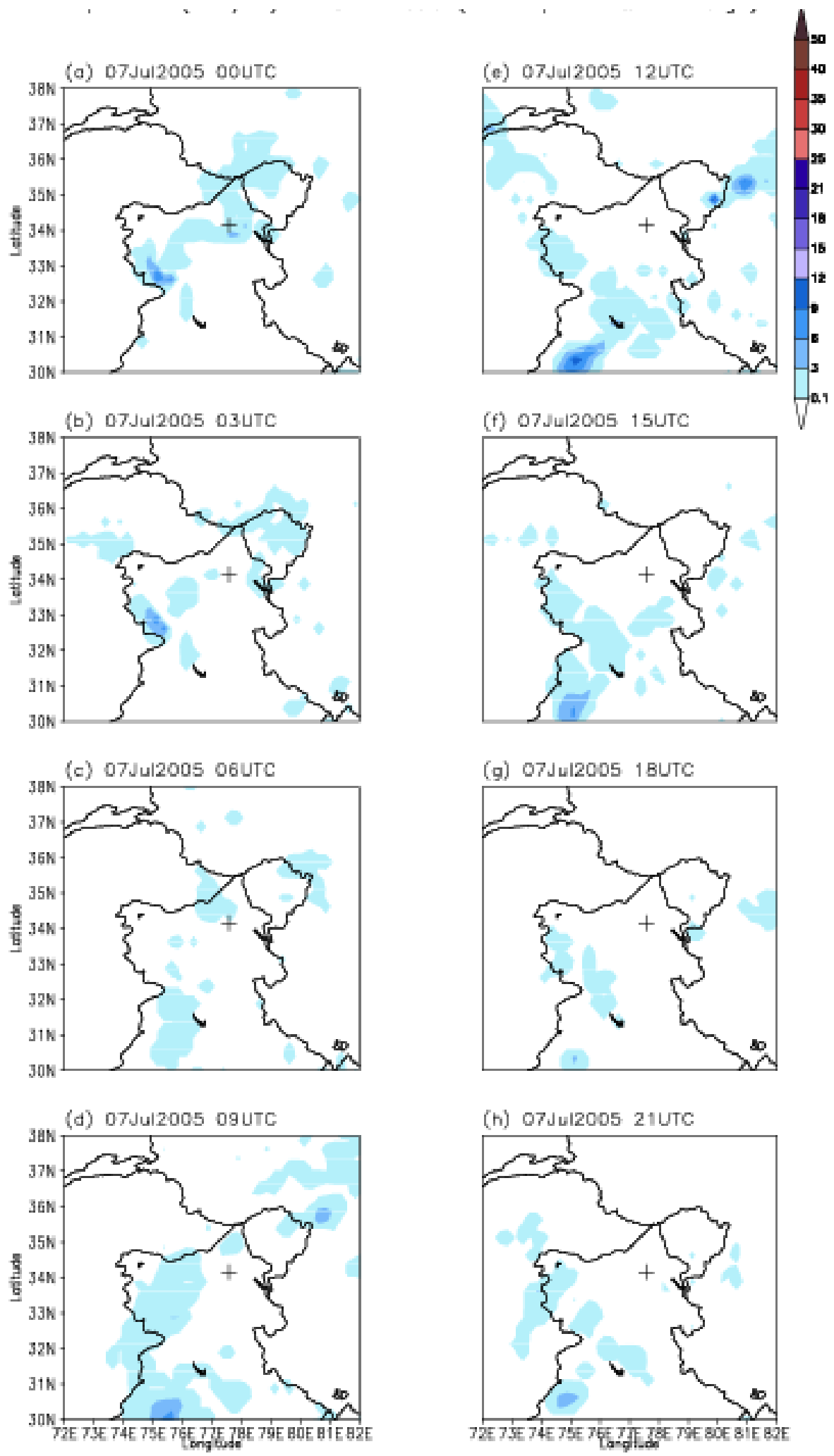

Fig. 5c. Same as Fig. 5a, but for 07Jul2005. 
$700 h P a$

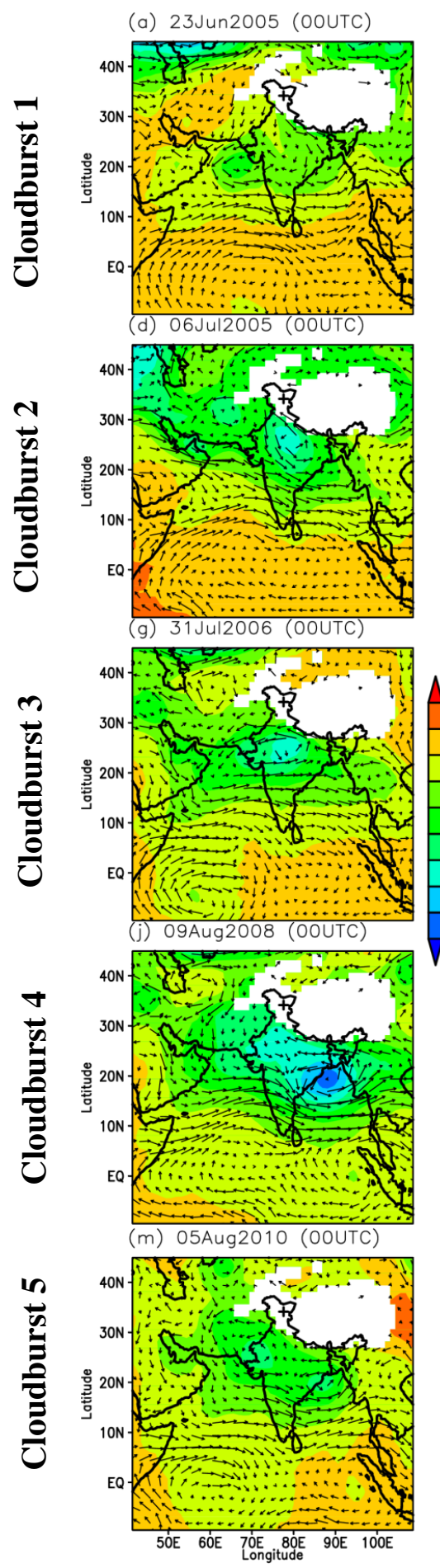

500hPa
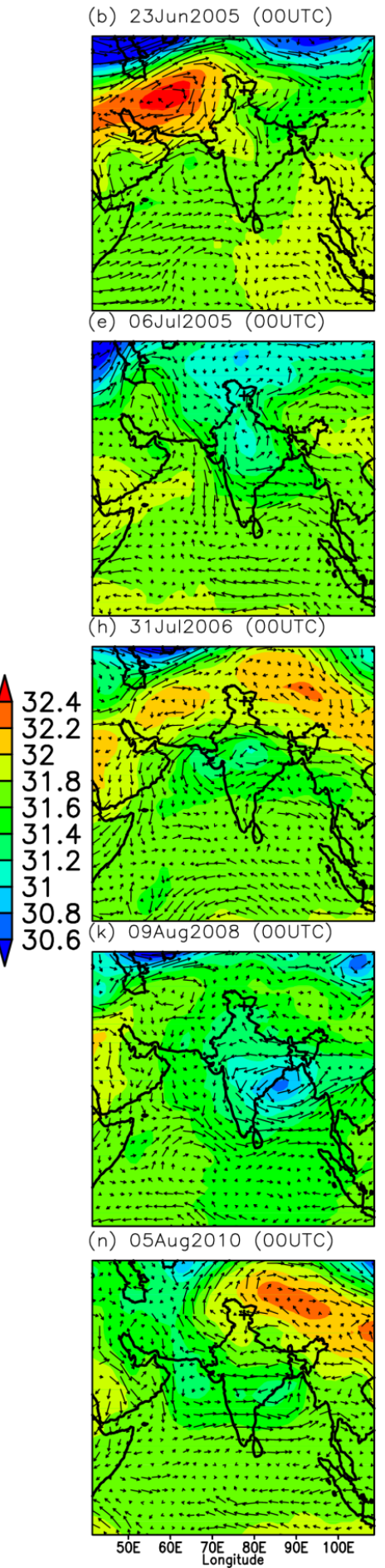

200hPa

(c) 23Jun2005 (OOUTC)
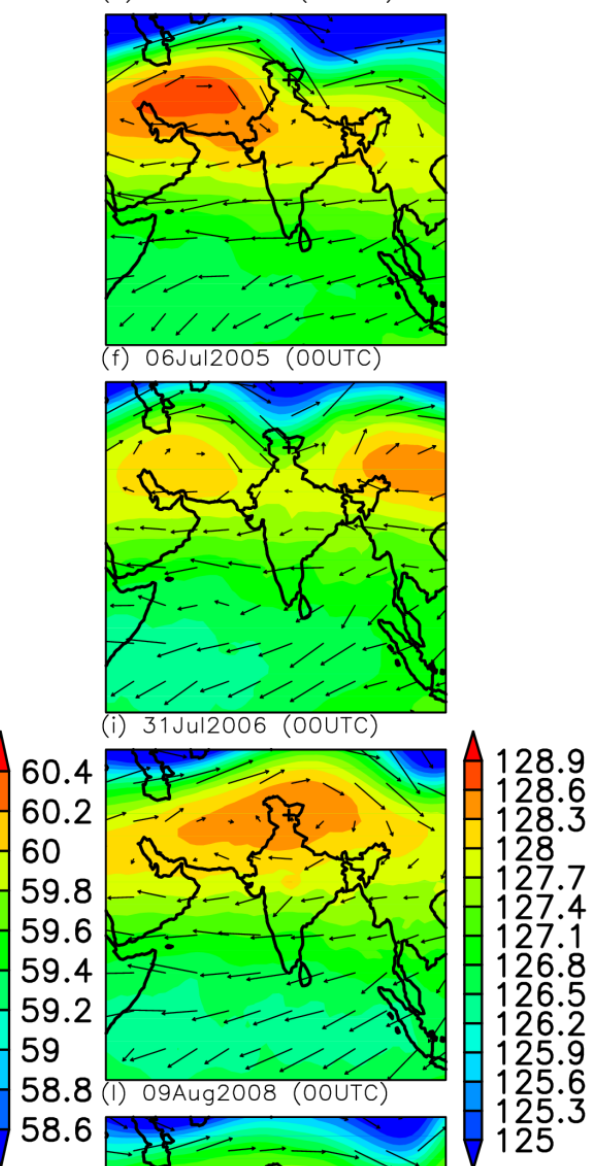
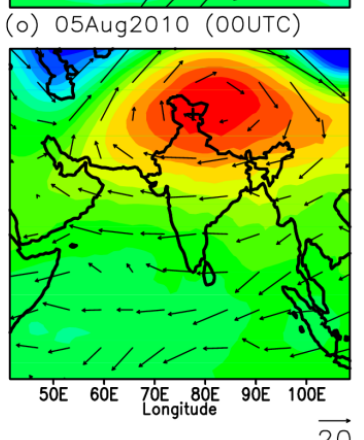

Fig. 6. Geopotential height (shaded; $\times 100 \mathrm{~m}$ ) and wind (vector; $\mathrm{m} / \mathrm{s}$ ) based on MERRA reanalysis for selected cloudburst event 1 on 23Jun2005(00UTC) at (a) $700 \mathrm{hPa}$, (b) $500 \mathrm{hPa}$ and (c) 200 hPa. $(\mathrm{d}-\mathrm{f})$ is same as $(\mathrm{a}-\mathrm{c})$, but for cloudburst event 2 on 06Jul2005 (00UTC). ( $\mathrm{g}-\mathrm{i})$ is same as $(\mathrm{a}-\mathrm{c})$, but for cloudburst event 3 on $31 \mathrm{Jul} 2006$ (00UTC). $(\mathrm{j}-1)$ is same as $(\mathrm{a}-\mathrm{c})$, but for cloudburst event 4 on 09Aug2008 (00UTC). $(\mathrm{m}-\mathrm{o})$ is same as $(\mathrm{a}-\mathrm{c})$, but for cloudburst event 5 on 05Aug2010 (00UTC). (Leh depicted with + sign). 

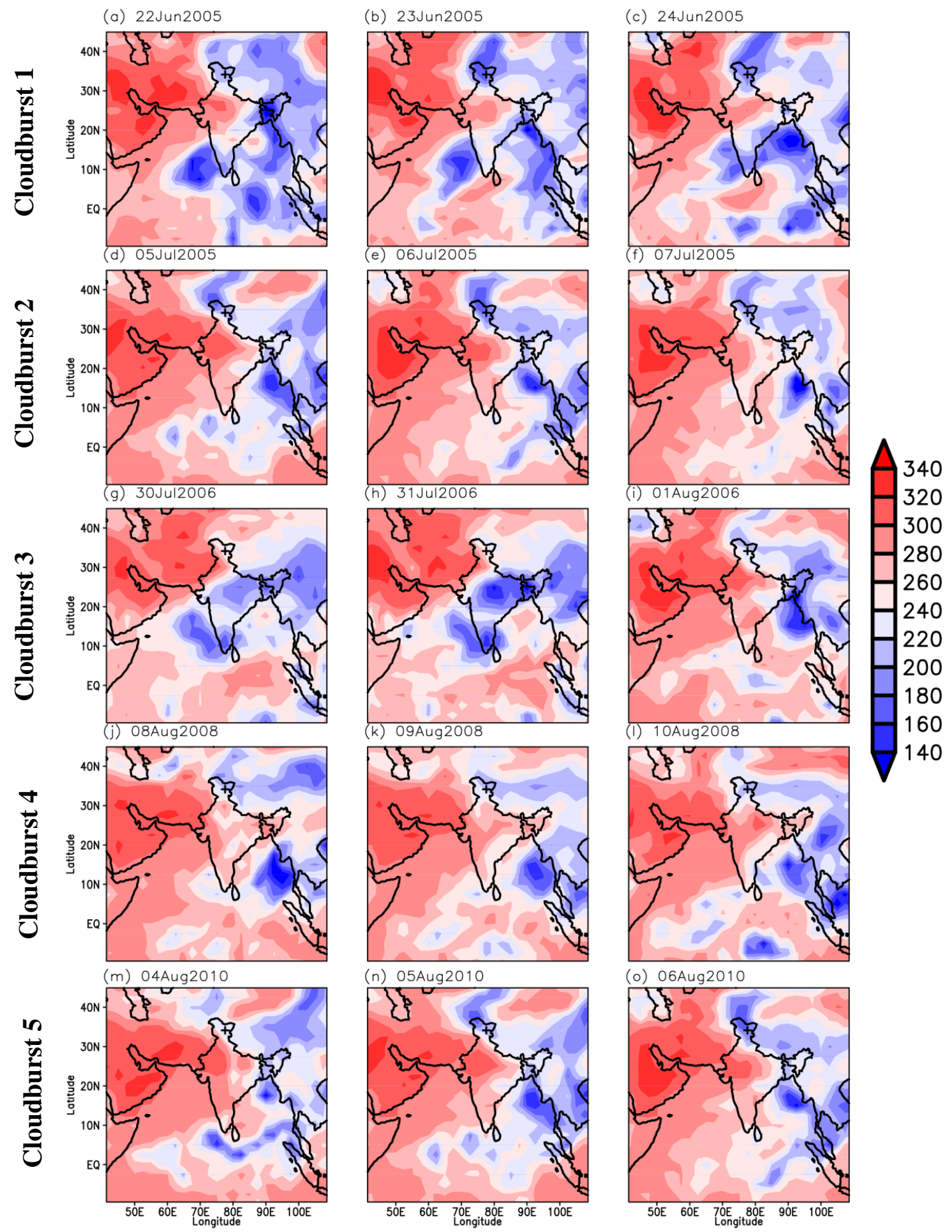

Fig. 7. Outgoing Longwave Radiation (shaded; $\mathrm{W} / \mathrm{m}^{2}$ ) based on NOAA data for selected cloudburst event 1 on (a) 22Jun2005, (b) 23Jun2005 and (c) 24Jun2005. (d-f) is same as (a - c), but for cloudburst event 2 on 05, 06 and 07Jul2005. ( $\mathrm{g}-\mathrm{i}$ ) is same as $(\mathrm{a}-\mathrm{c})$, but for cloudburst event 3 on 30, 31Jul2006 and 01Aug2006. ( $\mathrm{j}-\mathrm{k})$ is same as $(\mathrm{a}-\mathrm{c}$ ), but for cloudburst event 4 on 08, 09 and 10Aug2008. (m-o) is same as $(\mathrm{a}-\mathrm{c})$, but for cloudburst event 5 on 04,05 and 06Aug2010. (Leh depicted with + sign). 
(a) 22Jun2005
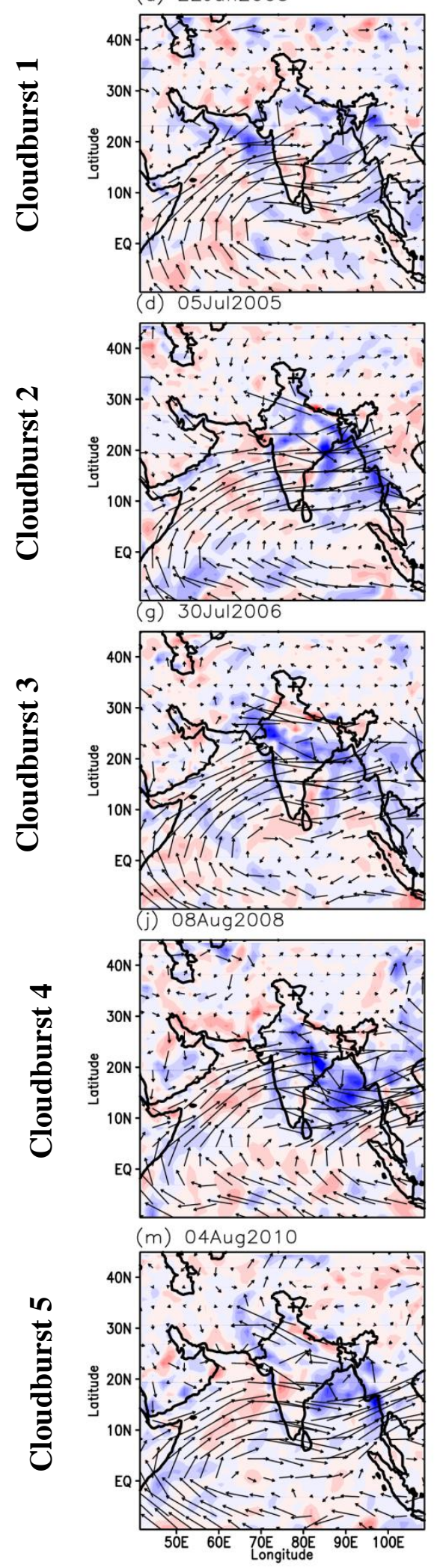

(b) 23Jun2005
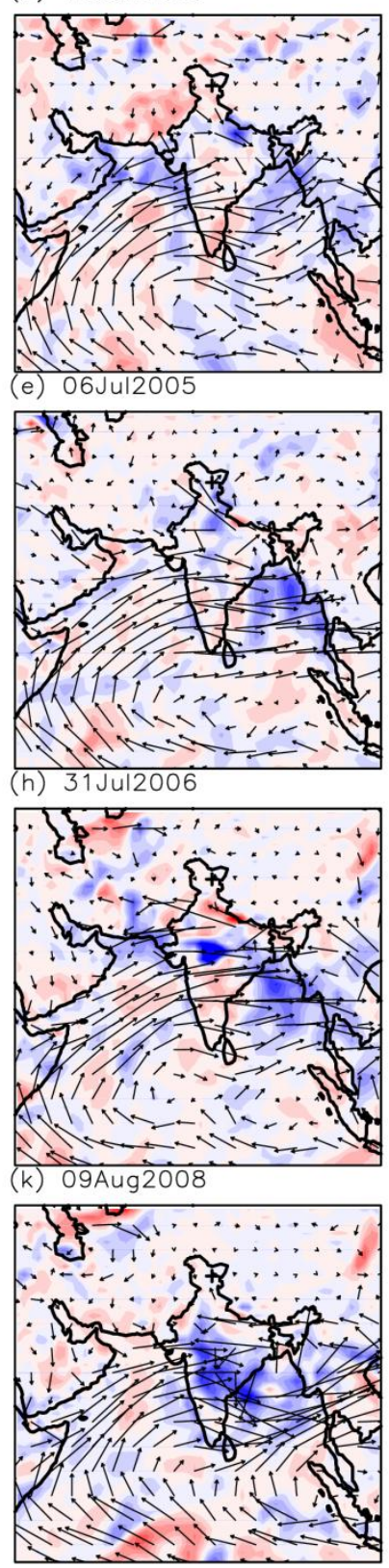

(n) 05Aug2010

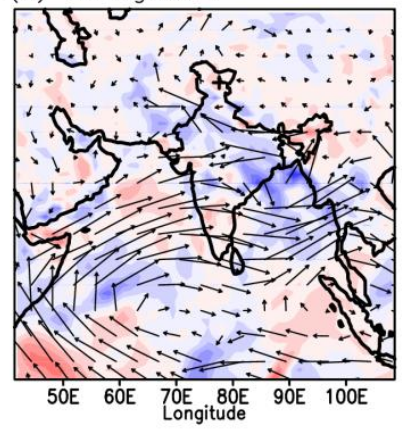

(c) 24Jun2005


(o) 06Aug2010

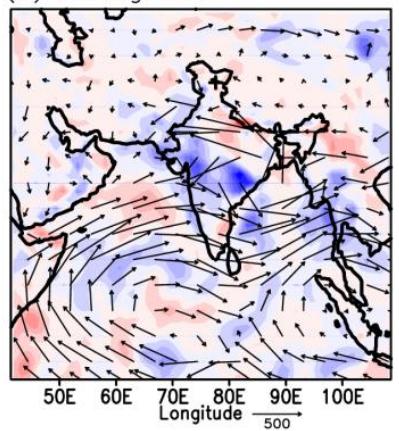

Fig. 8. Same as Fig. 7, but for vertical integrated moisture transport $(\mathrm{kg} / \mathrm{m} / \mathrm{s}$; vector) and flux $\left(\times 10^{-3} \mathrm{~mm}\right.$; shaded) based on MERRA reanalysis. (Leh depicted with + sign). 


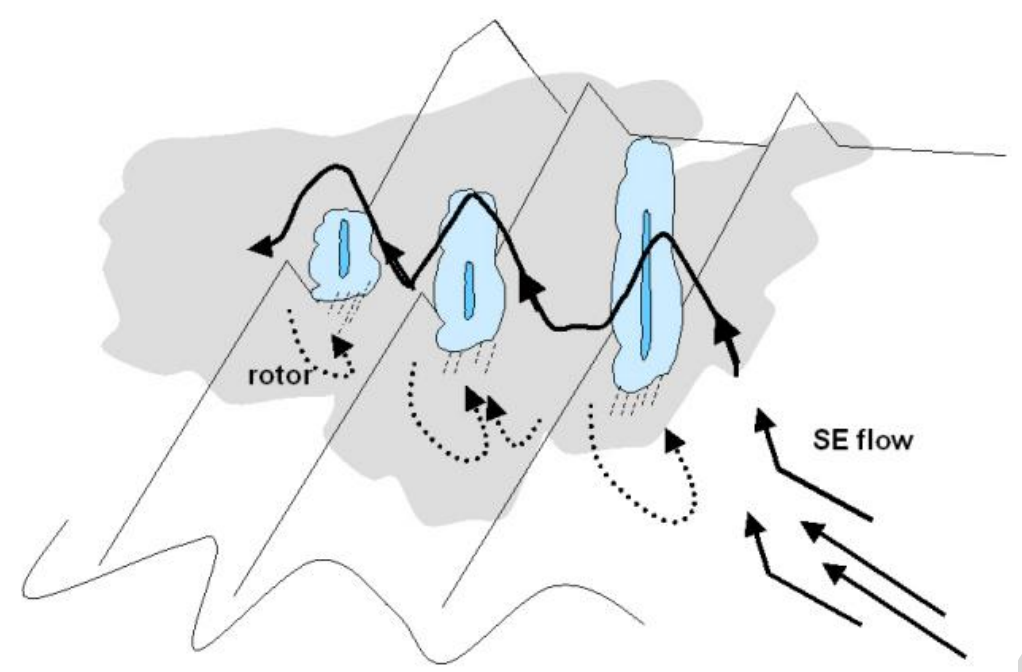

Fig. 9. Conceptual summary of the spatial distribution of precipitation forming mechanism and associated precipitation obtained in interactions with valley-ridge systems. (Continuous dark lines represent orographic gravity waves; dashed lines represent single-cell mountain valley circulations). (Source: Barros et al., 2004). 

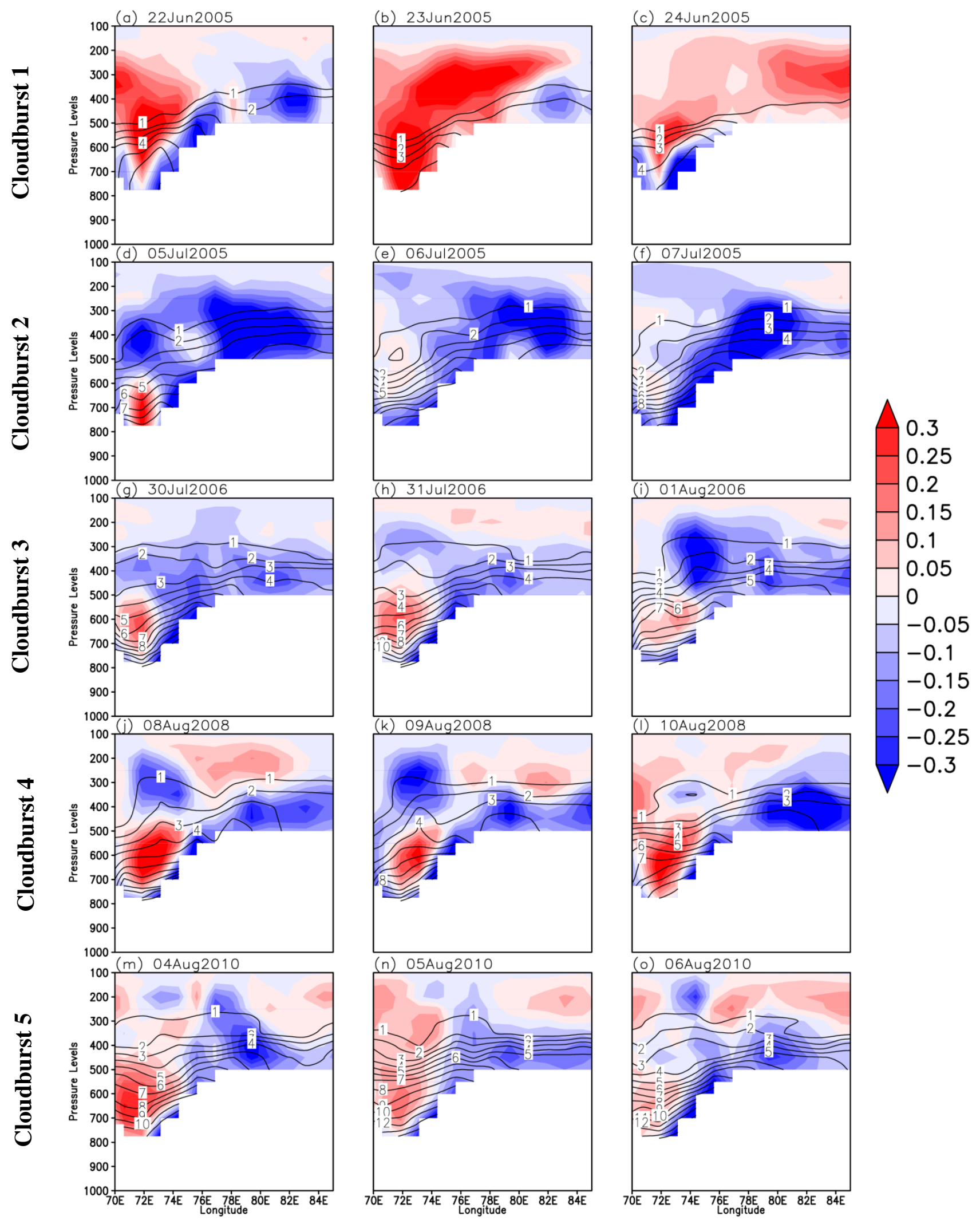

Fig. 10. Same as Fig. 7, but for vertical distribution of omega (shaded; $\mathrm{Pa} / \mathrm{s}$ ) and specific humidity (contour; $\times 10^{-3} \mathrm{~g} / \mathrm{kg}$ ) at $34.15^{\circ} \mathrm{N}$ latitude cross section based on MEERA reanalysis. 

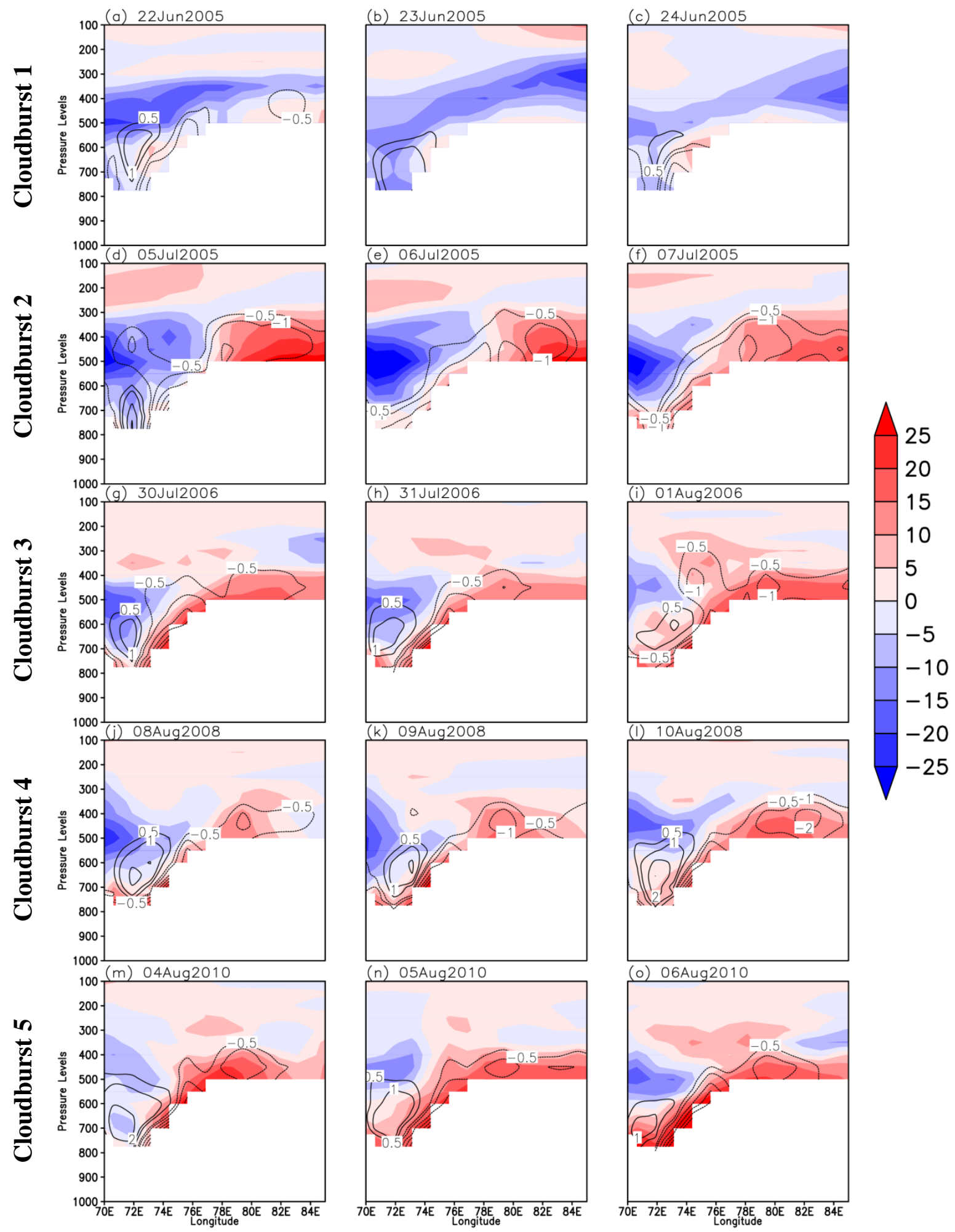

Fig. 11. Same as Fig. 10, but for vertical distribution of perturbation of equivalent potential temperature $(\mathrm{EPT})$ (shaded) and vertical moisture flux (contour; $\mathrm{Pa} / \mathrm{s}$ ). [Vertical moisture flux = Omega $\times$ Specific Humidity] 

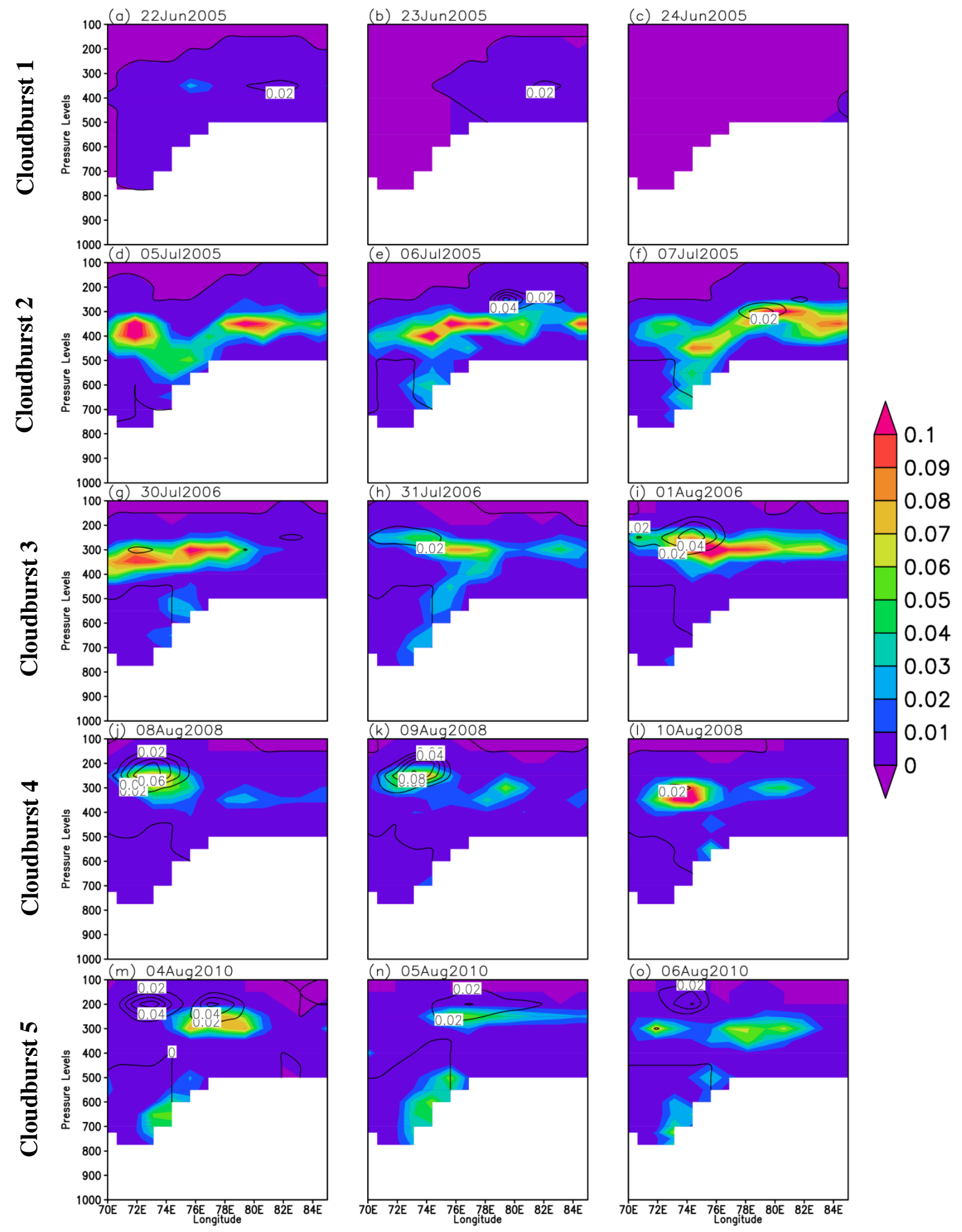

Fig. 12. Same as Fig. 10, but for vertical distribution of cloud liquid water mixing ratio $\left(\times 10^{-3}\right.$ $\mathrm{g} / \mathrm{kg}$; shaded $)$ and cloud ice mixing ratio $\left(\times 10^{-3} \mathrm{~g} / \mathrm{kg}\right.$; contour $)$. 

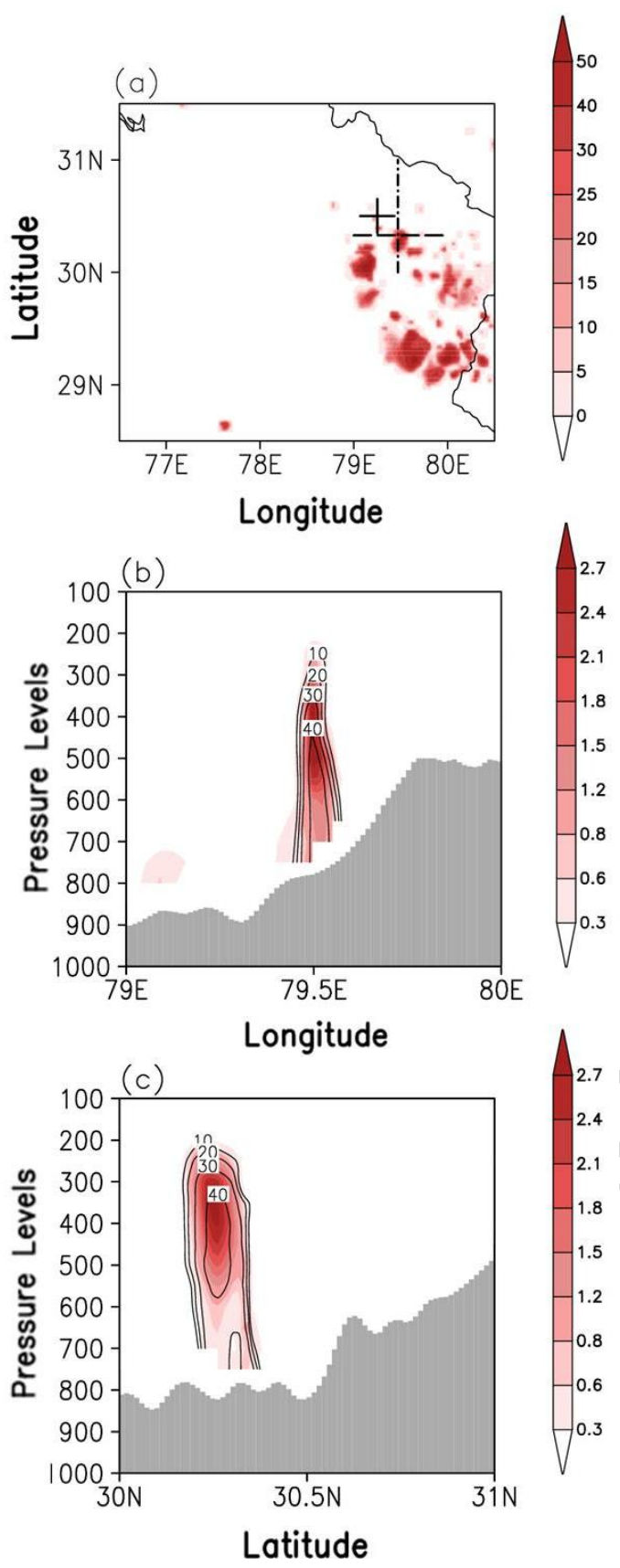

Fig. 13(a) Latitude-longitude distribution of maximum reflectivity (dBZ) (+ denotes Ukhimath and dotted $\times$ denotes $30^{\circ} 19^{\prime} 49^{\prime \prime} \mathrm{N}$; 79 $9^{\circ} 2^{\prime} 09^{\prime \prime} \mathrm{E}$ (exact location of maxima of reflectivity), (b) Longitude-pressure distribution of reflectivity (dBZ; contour) and composite mixing ratio of hydrometeors $(\mathrm{kg} / \mathrm{kg}$; shaded) along longer dashed line from figure 11a (at latitude $30^{\circ} 19^{\prime} 49^{\prime \prime} \mathrm{N}$ ), (c) Latitude-pressure distribution of reflectivity (dBZ; contour) and composite mixing ratio of hydrometeors $(\mathrm{kg} / \mathrm{kg}$; shaded) along shorter dashed line from figure 11a (at longitude 79 28' 09" E), for 13 September 201218 UTC at $3 \mathrm{~km}$ model resolution domain with explicit physics. Composite mixing ratio $(\mathrm{MR})$ of hydrometeors $=(\mathrm{MR}$ cloudwater + MR rainwater + MR cloudice + MR snow + MR graupel) (Source: Chevuturi et al., 2015). 
(a)

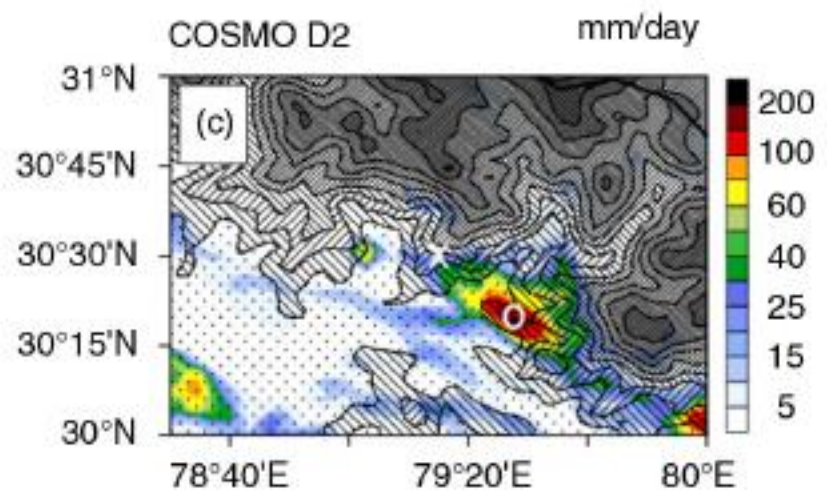

(b)
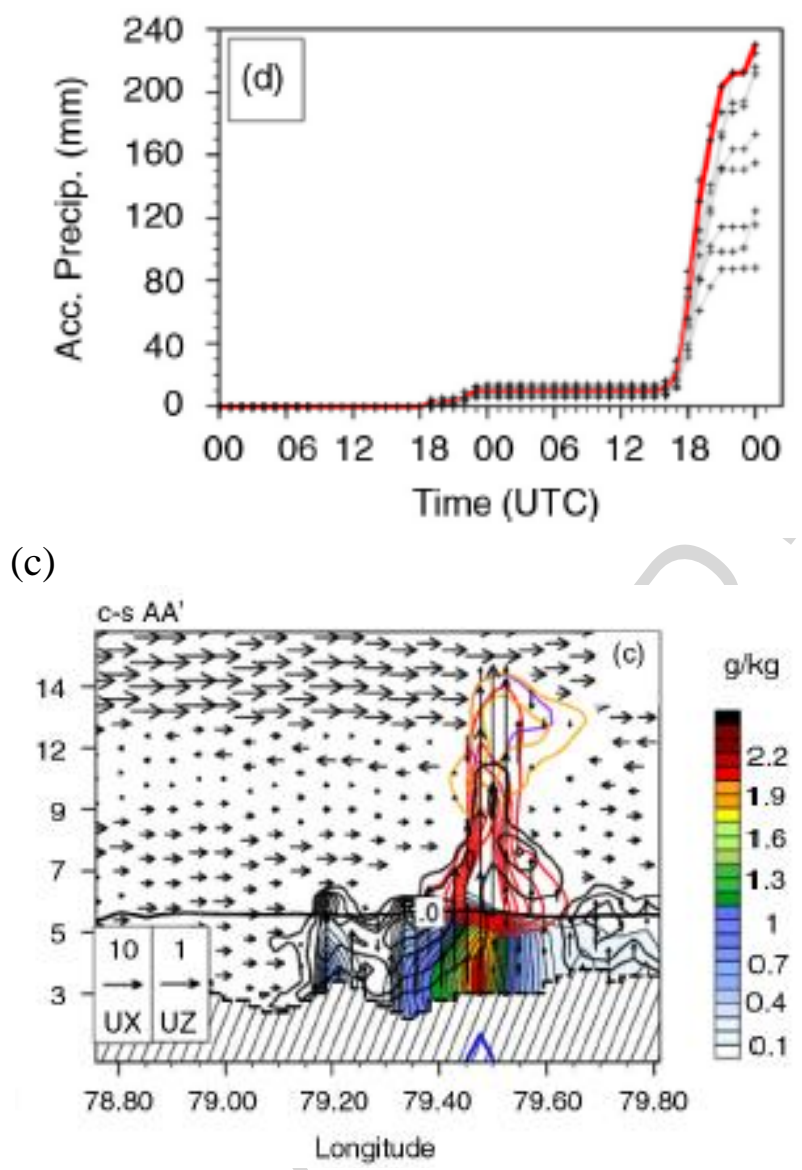

Fig. 14(a) Modelled accumulated precipitation with the local topography at the resolution of the D2 model domain $(2.8 \mathrm{~km})$. The topography contour interval is $500 \mathrm{~m}$ reaching from 2000 to $6000 \mathrm{~m}$ elevation. (b) Time-series of accumulated precipitation at location marked 'o' (red) and the surrounding grid cells (grey), starting 12 September 2012. The precipitation accumulation shown in the spatial distributions is derived from 0000 UTC to 2330 UTC. (c) (c) Cross-section AA' of hydrometeors (qr in colour shading, qc, qi, qg, qs in solid lines from 0.2 to $2.4 \mathrm{~g} / \mathrm{kg}$ at intervals of $0.4 \mathrm{~g} / \mathrm{kg}$ ), wind vectors and temperature (black contours, showing the melting level). [qx refers to mixing ratio of different hydrometeors, with $\mathrm{x}$ being cloud water (qc), cloud ice (qi), graupel (qg), snow (qs) and rain (qr)]. (Source: Shrestha et al., 2015). 

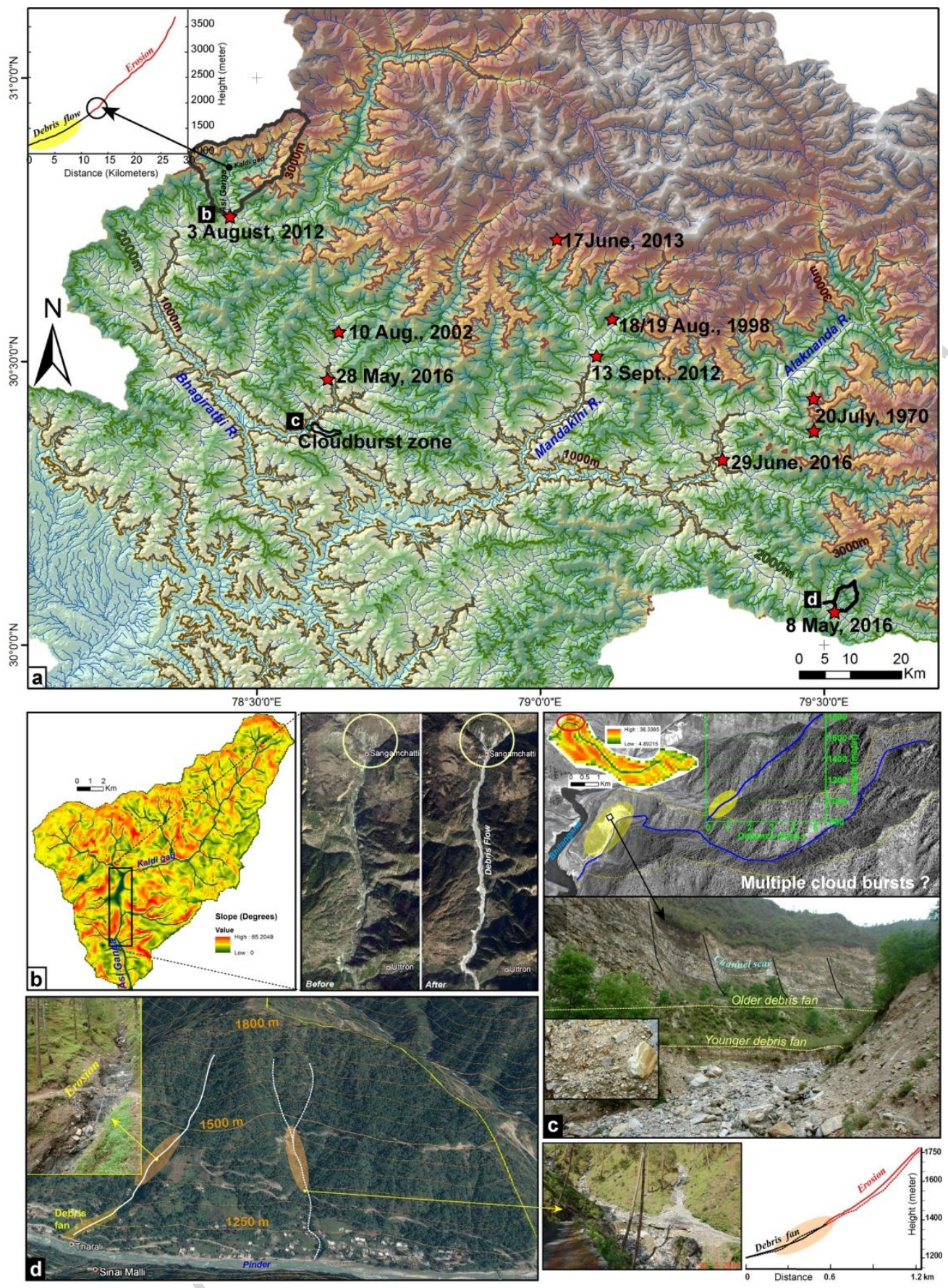

Fig. 15. (a) The DEM of upper Ganga catchment in Himalayan terrain overlaid with the contours of 1000, 2000 and $3000 \mathrm{~m}$, past cloud burst locations and the studied catchments. Please note the elevation profile of Asi Ganga river. (b) Slope pattern and Google images of pre- and post- 2 August, 2012 cloudburst clearly showing affected lower stretch of the glacial fed perennial Asi Ganga river catchment, a tributary of the Bhagirathi river . (c) PAN image, slope pattern, profile section and field photograph of the repeated cloud burst affected valley along a rain fed seasonal tributary stream of the Bhilangana river. Note the multiple channel scar and varnished level on the slope marking water level during transient floods. (d) Google image overlaid with the height contours of an open steep slope along the Pinder river affected by extreme precipitation on 8th May, 2016. Note the profiles and gradational landform developed during the rain. 
(a)

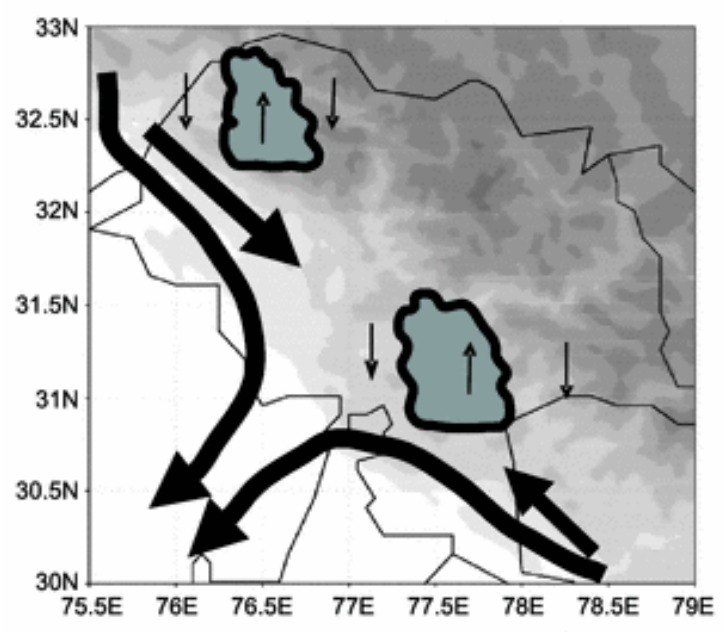

(a) Stage-1: 06:30 LT Separate Cells

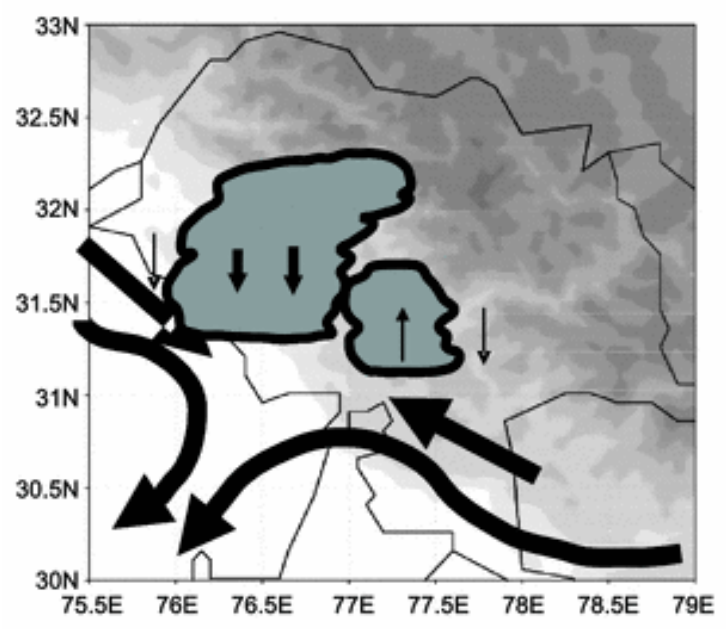

(b) Stage-2: 08:30 LT Merger cells and downpour

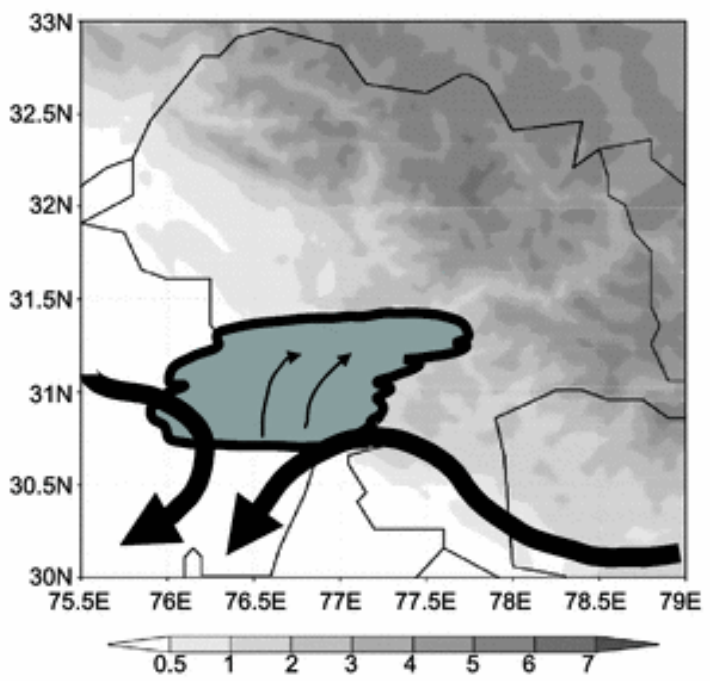

(c) Stage-3: 12:30 LT Dissipation (b)

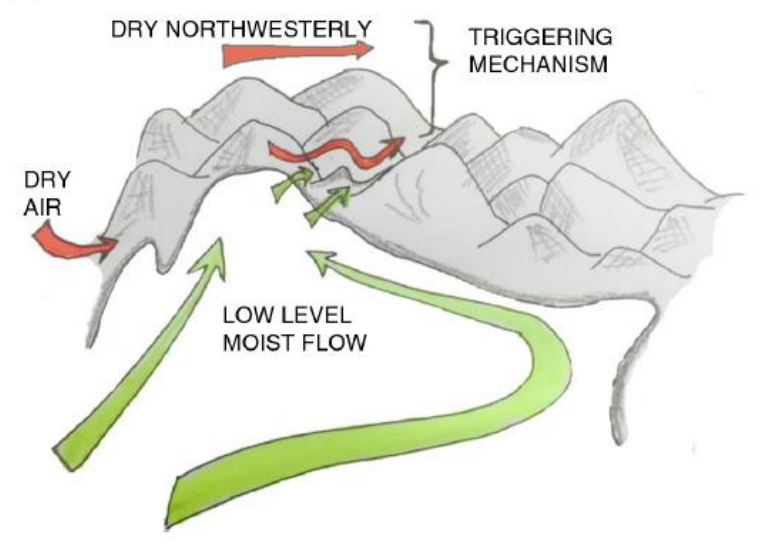

(c)

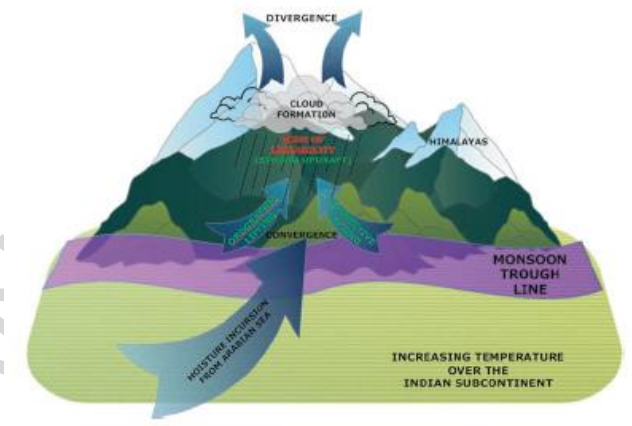

(d)

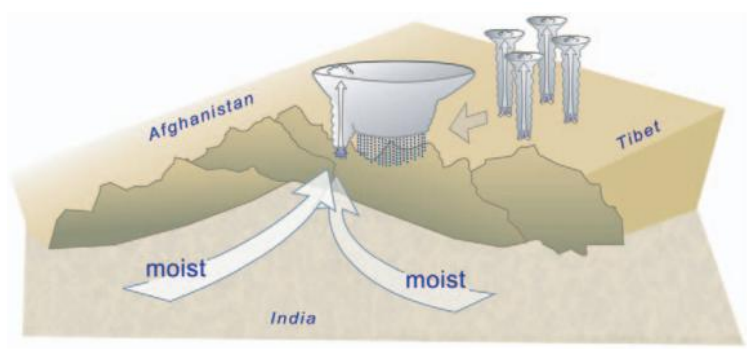

(e)

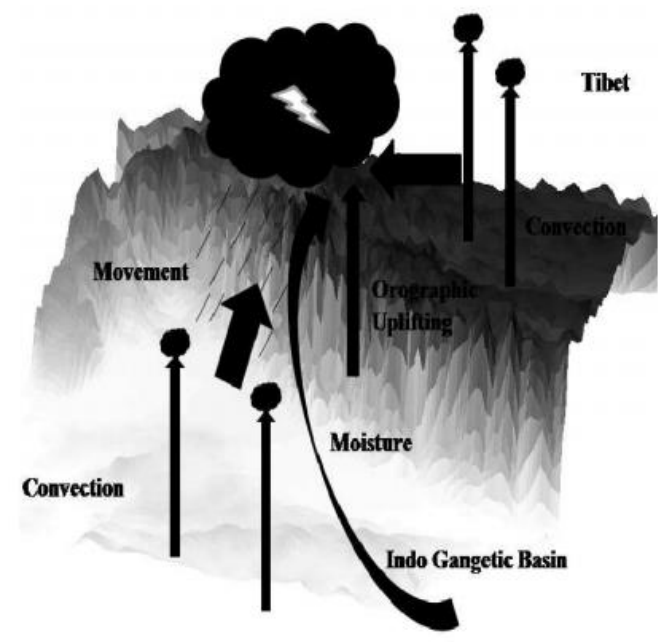

Fig. 16. Conceptual diagram leading to cloudburst mechanism over the southern rim of the Indian Himalayas proposed by (a) Das et al. (2006), (b) Shrestha et al. (2015), (c) Chevuturi et al. (2015), (d) Rasmussen and Houze Jr. (2012) and (e) Chaudhuri et al. (2015). 


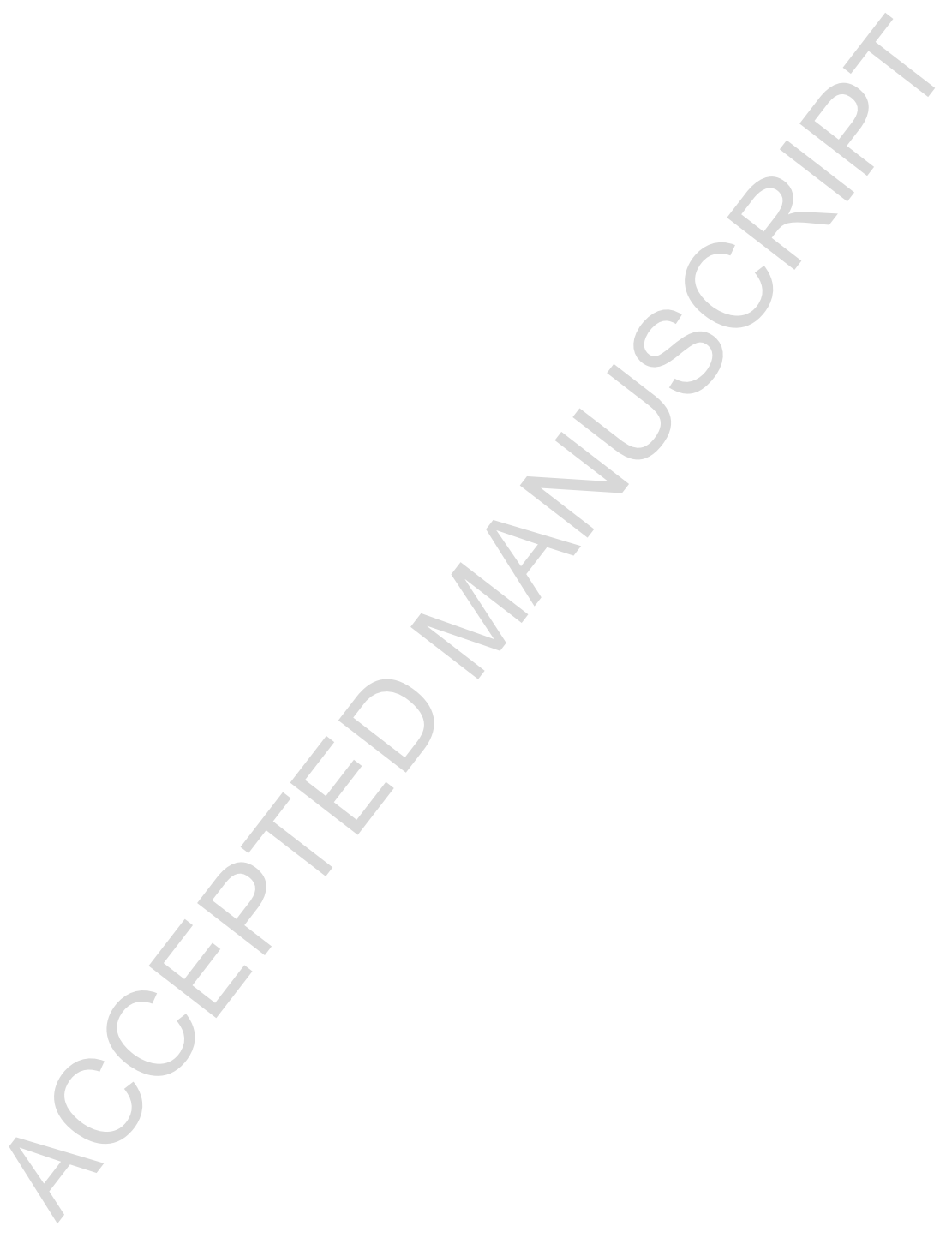

